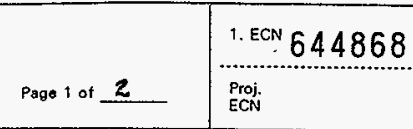

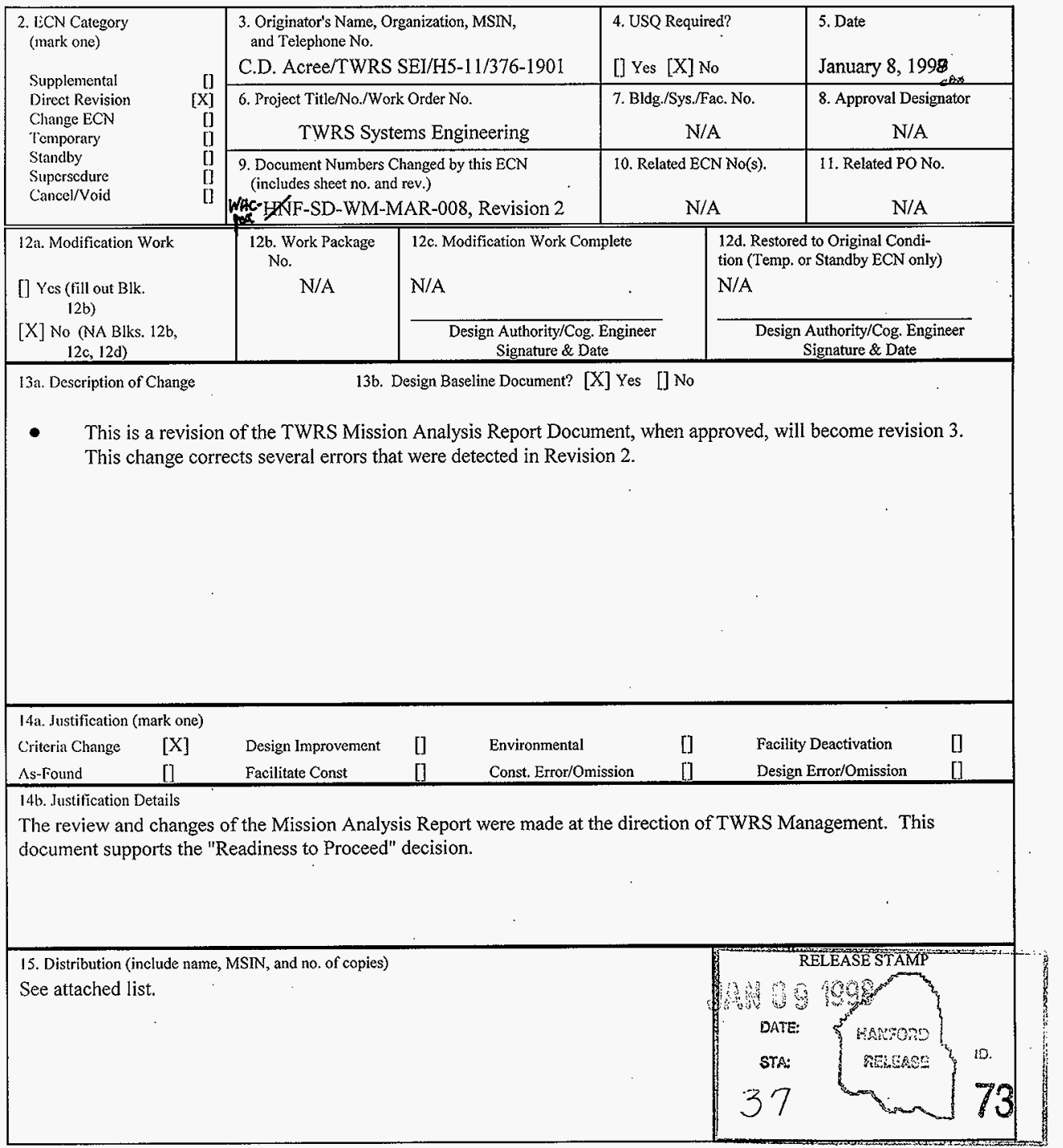




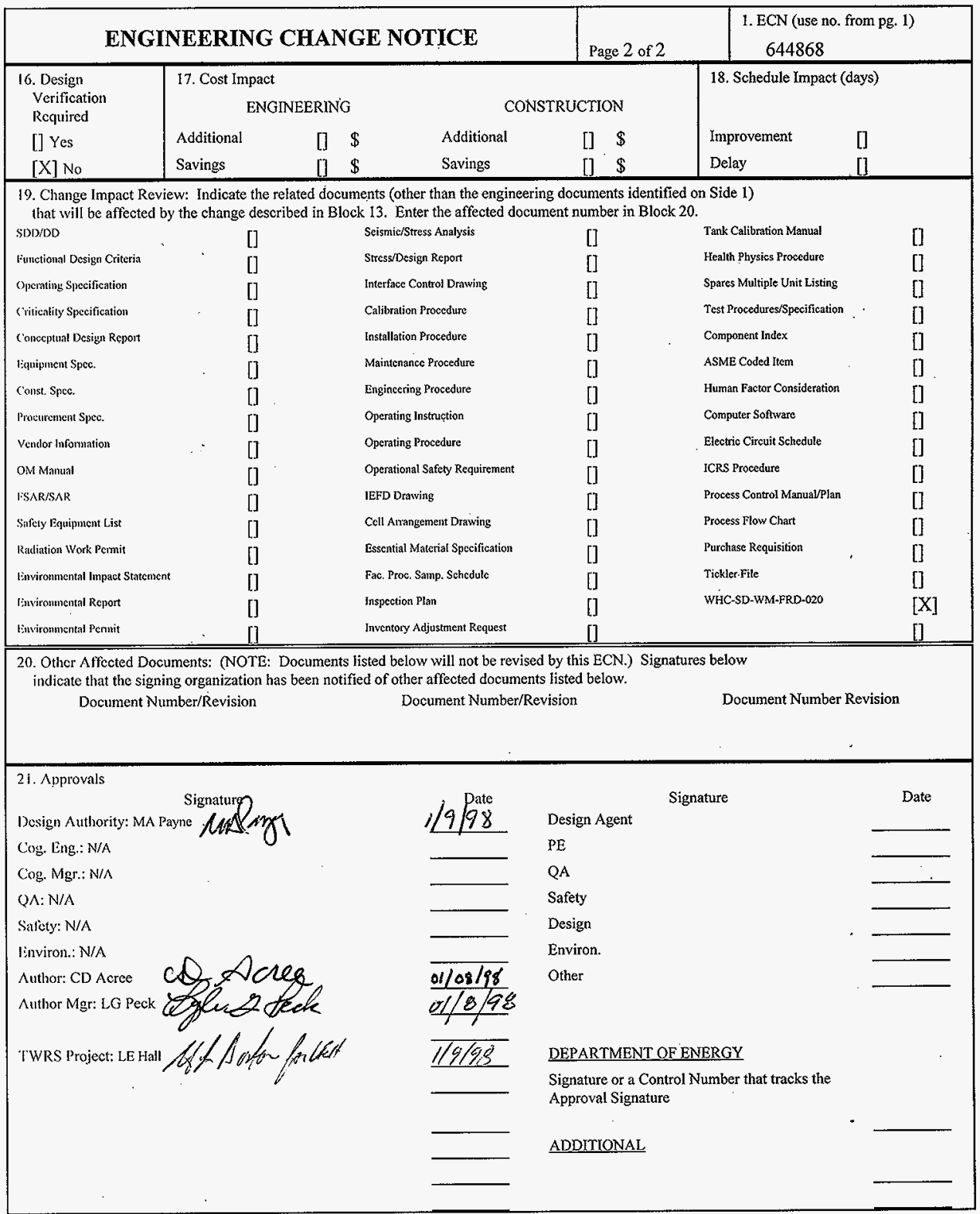




\title{
Tank Waste Remediation System Mission Analysis Report
}

\author{
C.D. Acree, Jr. \\ Lockheed Mart in Hanford Company, Richland, WA 99352 \\ U.S. Department of Energy Contract DE-AC06-96RL13200
}

$\begin{array}{llll}\text { EDT/ECN: } & \text { ECN-644868 } & \text { UC: } 2030 \\ \text { Org Code: } & 76000 & \text { Charge Code: } & \text { D215P } \\ \text { B\&R Code: } & \text { EW3130010 } & \text { Total Pages: } & 143 \text { (4I low } \\ \text { Key Words: } & \text { TWRS, Mission Analysis } & \end{array}$

Abstract: This document describes and analyzes the technical requirements that the Tank Waste Remediation System (TWRS) must satisfy for the mission. This document further defines the technical requirements that TWRS must satisfy to supply feed to the private contractors' facilities and to store or dispose the immobilized waste following processing in these facilities. This document uses a twophased approach to the analysis to reflect the two-phased nature of the mission.

TRADEMARK DISCLAIMER. Reference herein to any specific comerciat product, process, or service by trade name, tradenark, manufacturer, or otherwise, does not necessarily constitute or imply its endorsement, recommendation, or favoring by the United States Government or any agency thereof or its contractors or subcontractors.

Printed in the United States of America. To obtain copies of this document, contact: Document Control Services, P.0. Box 950, Mailstop H6-08, Richland WA 99352, Phone (509) 372-2420; Fax (509) 376-4989.
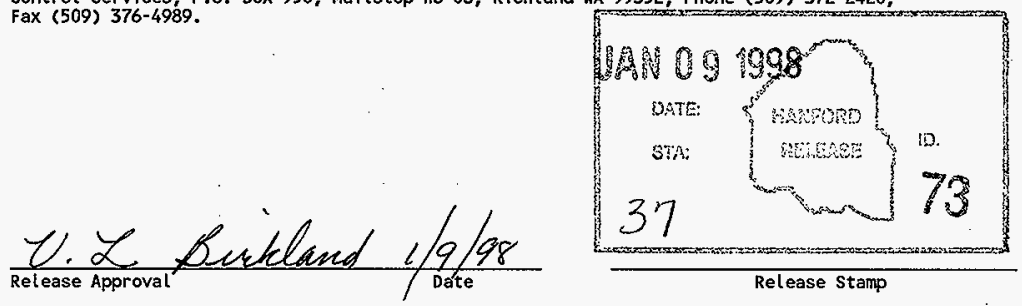


\section{RECORD OF REVISION}

(2) Title

TANK WASTE REMEDIATION SYSTEM MISSION ANALYSIS REPORT

CHANGE CONTROL RECORD

(3) Revision

\begin{tabular}{|c|}
\hline 0 \\
\hline 1 \\
\hline 2 \\
\hline
\end{tabular}

$3 \mathrm{RS}^{-1}$
(4) Description of Change - Replace, Add, and Delete Pages

(7) Rev. 0, EDT \#61559 9-18-95

Complete revision per ECN-628815

Major revision per ECN-630747

(document number changed to HNF-SD-WM-MAR-008)
Authorized for Release

(5) Cog. Engr.

(6) Cog. Mgr.

Date

CD Acree

LG Peck

\begin{tabular}{|c|c|c|c|}
\hline & 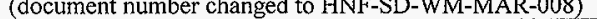 & & \\
\hline $3 \mathrm{RS}^{-1}$ & Direct revision of the TWRS MAR per ECN-644868 & CD Acree 4 the & 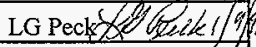 \\
\hline & & & \\
\hline & & & \\
\hline &. & & \\
\hline & & & \\
\hline & & & \\
\hline & & & \\
\hline & & & . \\
\hline & & & \\
\hline & & & \\
\hline & & & \\
\hline & & . & \\
\hline & & & \\
\hline & & & \\
\hline & & & \\
\hline & & & \\
\hline & 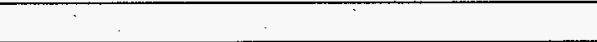 & & \\
\hline & . & . & \\
\hline & . & & \\
\hline & & & \\
\hline & & & \\
\hline & & & \\
\hline & . & & \\
\hline
\end{tabular}




\section{Tank Waste Remediation System Mission Analysis Report}

C. D. Acree, Jr.

Lockheed Martin Hanford Corporation

Date Published

January 1998

Prepared by Lockheed Martin Hanford Corporation

Richland, Washington

Prepared for the U.S. Department of Energy

(7) Fluor Daniel Hanford, Inc.

Richland, Washington

Hanford Management and Integration Contractor for the

U.S. Department of Energy under Contract DE-AC-0696-RL13200 
LEGAL DISCLAIMER

This report was prepared as an account of work sponsored by an ageney of the United States Government. Neither the United States Government nor any agency thereof, nor any of their employees, nor any of their contractors, subcontractors or their employees, makes any warranty, express or implied, or assumes any legal liability or responsibility for the accuracy, completeness, or any third party's use or the results of such use of any information, apparatus, product, or process disclosed, or represents that its use would not infringe privately owned rights. Reference herein to any specific commercial product, process, or service by trade name, trademark, manufacturer, or otherwise, does not necessarily constitute or imply its endorsement, recommendation, or favoring by the United States Government or any agency theref or its contractors or subcontractors. The views and opinions of authors expressed herein do not necessarily state or reflect those of the United States Government or any agency thereof.

This report has been reproduced from the best available copy. Available in paper copy and microfiche

Available to the U.S. Department of Energy

and its contractors from

U.S. Department of Energy

Office of Scientific and Technical Information (OSTI)

P.O. Box 62

Oak Ridge TN 37831

(615) $576-8401$

Available to the public from the U.S. Department of Commerce National Technical Information Service (NTIS)

5285 Port Royal Road

Springfield, VA 22161

(703) 487.4650

Printed in the Unired States of America

DISCLM-1.CHP (8-95) 
HNF-SD-WM-MAR-008 Rev 3

This page intentionally left blank. 
HNF-SD-WM-MAR-008 Rev 3

Document Titie: Tank Waste Remediation System Mission Analysis Report

Approved by:
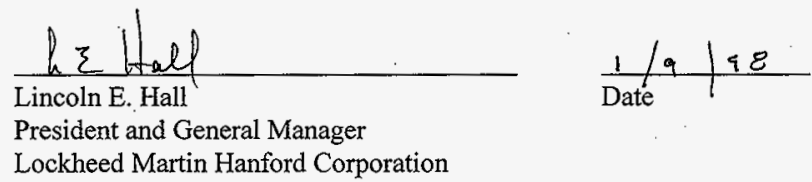

Lockheed Martin Hanford Corporation 
FNF-SD-WM-MAR-008 Rev 3

This page intentionally left blank. 
HNF-SD-WM-MAR-008 Rev 3

\section{EXECUTIVE SUMMARY}

This Mission Analysis Report provides an analysis of the Tank Waste Remediation System (TWRS) mission. An overall systems approach was applied to develop action plans to support the retrieval and disposal mission. An analysis of the programmatic, management, and technical activities necessary to declare readiness to proceed with execution of the mission showed that the systems, personnel, and hardware will be on line and ready to support the mission: The analysis concluded that the systems and infrastructure required to support the mission have been identified. Required systems are either in place or plans have been developed to ensure that they will exist when required by the mission. The analysis showed that since October 1996, a robust systems approach has been developed, integrating Technical Baselines, Work Breakdown Structures, tank farm struchure, and engineering configurations.

The systems approach included defining the TWRS Project mission requirements and evaluating the readiness of TWRS to supply waste feed and provide storage and disposal facilities for immobilization of high-and low-level waste, during Phase $1 B$, to the private contractors commencing in June 2002. The Phase I feed delivery requirements from the Phase lA private contracts have been analyzed. Transfer piping routes were mapped, existing systems were evaluated, and upgrade requirements were defined. The TWRS personnel training, qualifications, management systems, and procedures meet expectations for current operations, and form the basis to support the Phase IB mission. Key assumptions and risks that conld negatively impact mission success were eyaluated and appropriate mitigative action plans were planned and scheduled. An integrated program management plan for the retrieval and disposal 
mission was developed to describe the overall management approach, organization roles and responsibilities, and overall performance measures.

A.preliminary analysis of the Phase $I B$ and Phase 2 feed staging and processing mission to accelerate the removal of waste from the single-shell tanks was conducted. The analysis indicates that extending the Phase 1 schedules could enhance the effectiveness and feasibility of the mission. This extension would continue the use of the Phase $1 B$ immobilization plants and maximize their capacity used during Phase 1 activities. This early start results in a much smaller scale-up requirement for full-scale production facilities by allowing a decrease in peak retrieval requirements to more manageable rates while still meeting the Hanford Federal Facility Agreement and Consent Order ${ }^{*}$ completion of processing dates. This early start also provides the U.S. Department of Energy an opportunity to reduce the overall immobilization costs by reducing the production capacity and non-recurring investment now specified for the private contractors.

This systematic review of the Project Hanford Management Contract Team 's ability to support the retrieval and disposal mission concludes that the systems and infrastructure required to support this mission are understood and in place or plans are in place to ensure that they will exist when needed. A robust systems engineering culture, management system, and risk management program are in place. No technology breakthroughs are needed to achieve a manageable schedule for Phase 1 . In short, the review shows that the systems, personnel, and hardware are ready to proceed.

"Ecology, EPA, and DOE, 1996, Hanford Federal Facility Agreement and Consent Order, 2 vol., Washington State Department of Ecology, U.S. Environmental Protection Agency, and U.S. Department of Energy, Olympia, Washington. 


\section{CONTENTS}

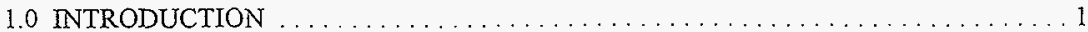

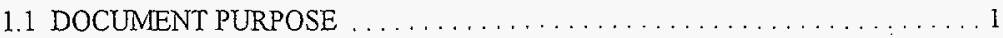

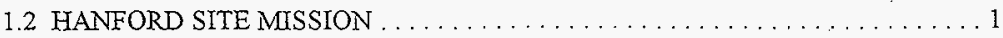

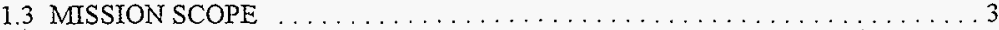

1.4 TANK WASTE REMEDIATION SYSTEM HISTORY $\ldots \ldots \ldots \ldots \ldots \ldots$

2.0 TANK WASTE REMEDIATION SYSTEM PROBLEM $\ldots \ldots \ldots \ldots \ldots \ldots \ldots . \ldots$

2.1 PROBLEM BACKGROUND $\ldots \ldots \ldots \ldots \ldots \ldots \ldots \ldots \ldots \ldots \ldots \ldots$

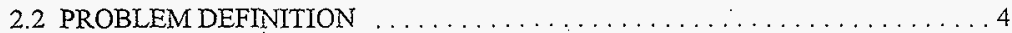

2.3 TANK WASTE REMEDIATION SYSTEM MAJOR ISSUES OVERVIEW . . . . 5

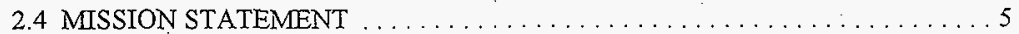

3.0 TANK WASTE REMEDIATION SYSTEM MISSION $\ldots \ldots \ldots \ldots \ldots \ldots \ldots$

3.1 MISSION MANAGEMENT APPROACH $\ldots \ldots \ldots \ldots \ldots \ldots \ldots \ldots \ldots$

4.0 TANK WASTE REMEDIATION SYSTEM BOUNDARY AND INTERFACES $\ldots \ldots 7$

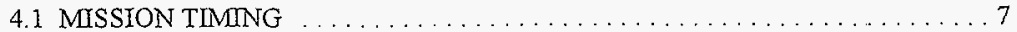

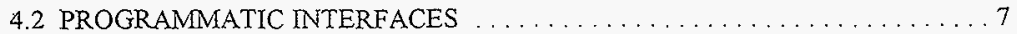

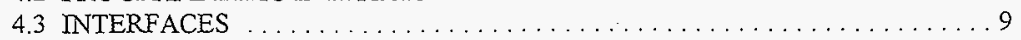

5.0 TANK WASTE REMEDIATION SYSTEM INITIAL STATES, INPUTS, OUTPUTS,

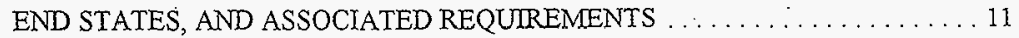

5.1 APPLICABLE SOURCES FOR EXTERNALLY IMPOSED REQUIREMENTS 11

5.2 TANK WASTE REMEDIATION SYSTEM INITIAL STATES $\ldots \ldots \ldots \ldots 12$

5.2.1 Single-Shell Tanks and Double-Shell Tanks . . . . . . . . . . . 12

5.2 .2 Miscellaneous Underground Storage Tanks ............... 12

5.2 .3 Existing Tank Waste ........................... 14

5.2.4 Tank Equipment and Other Waste Materials ................ 14

5.2.5 Other Tank Waste Remediation System Facilities ............. 15

5.2.6 Phase 2 Mission - Tank Waste Remediation System Initial States . . . . 15

5.3 TANK WASTE REMEDIATION SYSTEM INPUTS AND OUTPUTS $\ldots \ldots 15$

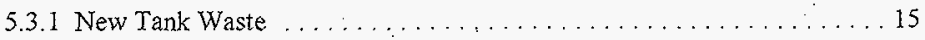

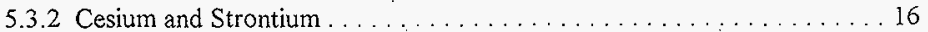

5.3 .3242 -A Evaporator Feed ....................... 18

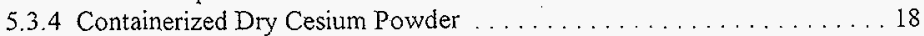

5.3 .5 Other Radioactive Wastes . . . . . . . . . . . . . . . . . . . 18

5.3 .6 Gaseous Effluents . . . . . . . . . . . . . . . . . . . . . 18

5.3 .7 Liquid Effluents . . . . . . . . . . . . . . . . . . . . . 19

5.3 .8 Solid Waste ..................................... 20

5.4 TANK WASTE REMEDIATION SYSTEM END STATES $\ldots \ldots \ldots \ldots \ldots 20$

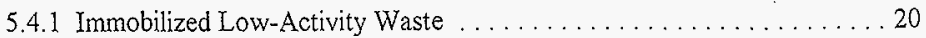

5.4.2 Immobilized High-Level Waste and Transuranic Waste ............ 20 


\section{CONTENTS (Continued)}

5.4 .3 Closed Single-Shell Tank System . . . . . . . . . . . . . . . 21

5.4 .4 Closed Double-Shell Tank System . . . . . . . . . . . . . . . . 24

5.4 .5 Closed Miscellaneous Underground Storage Tanks . . . . . . . . . 24

5.4 .6 Excess Facilities . . . . . . . . . . . . . . . . . . . . . . 24

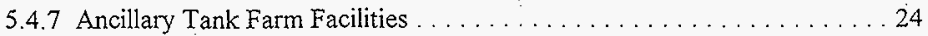

5.4.8 Beneficial Materials, Reusable Materials, and Technology Transfer .... 25

5.4.9 Phase 2 Mission - Tank Waste Remediation System End States ...... 25

6.0 TANK WASTE REMEDIATION SYSTEM OPERATIONS AND MAINTENANCE

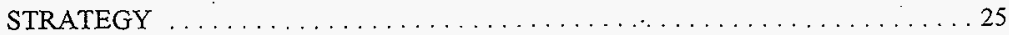

6.1 OPERATIONS STRATEGY OVERVIEW $\ldots \ldots \ldots \ldots \ldots \ldots \ldots \ldots \ldots 26$

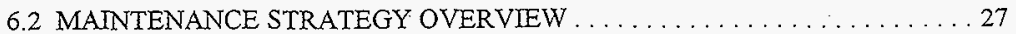

7.0 TEST AND EVALUATION PROCESSES FOR THE TANK WASTE REMEDIATION

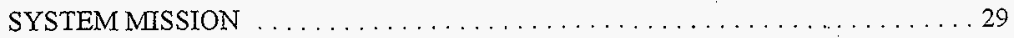

7.1 TEST AND EVALUATION OVERVIEW $\ldots \ldots \ldots \ldots \ldots \ldots \ldots \ldots \ldots$

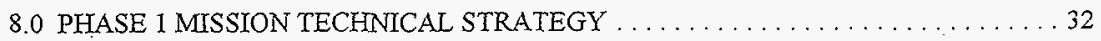

8.1 STRATEGIES COMMON TO PHASE 1 AND PHASE 2 MISSIONS . . . . . 32

8.2 PHASE 1 MISSION TECHNICAL STRATEGIES $\ldots \ldots \ldots \ldots \ldots \ldots \ldots 32$

9.0 PHASE 1 MISSION GOALS, OBJECTIVES, AND MEASURES OF SUCCESS . . . . 33

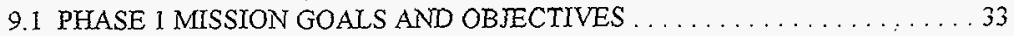

9.2 PHASE 1 MISSION MEASURES OF SUCCESS $\ldots \ldots \ldots \ldots \ldots \ldots \ldots$

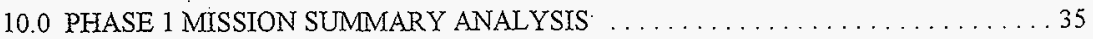

10.1 PHASE 1 MISSION ANALYSIS INTRODUCTION $\ldots \ldots \ldots \ldots \ldots \ldots . \ldots 36$

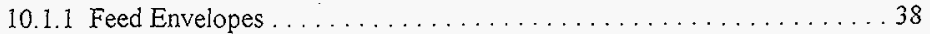

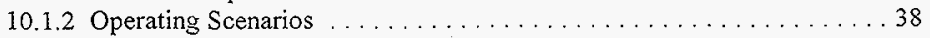

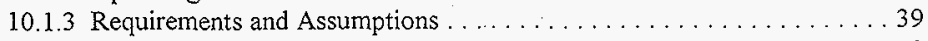

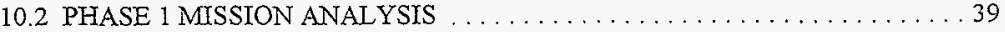

10.2.1 Phase 1 Low-Activity Waste Feed Processing . . . . . . . . . . . . 39

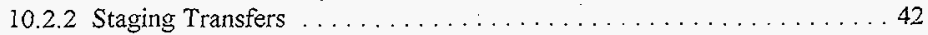

10.2.3 Batch Cycle Time ......................... 42

10.2.4 Phase 1 Immobilized Low-Activity Waste Package Processing . . . . . 45

10.2.5 Phase 1 High-Level Waste Feed Processing .............. 46

10.2.6 Phase 1 Immobilized High-Level Waste Canister Processing . . . . . . 48

10.3 TANIK WASTE REMEDIATION SYSTEM FACILITIES REQURRED FOR THE

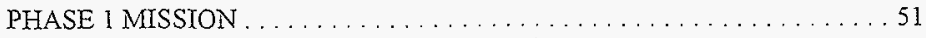

10.3.1 Tank Waste Remediation System Facilities' Life-Cycle Overview . . . . 51

10.3.2 Phase 1 Mission - Required Facilities ................. 53

10.3.3 Phase 1 Mission Facilities' Functional Requirements . . . . . . . . 54 


\section{CONTENTS (Continued)}

10.3.4 Equipment Upgrades and New Facilities to Support Phase 1B . . . . 54

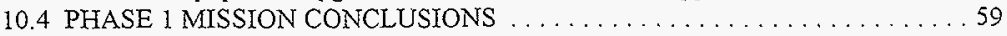

10.4.1 Feed Staging Conclusions and Recommendations ...........61

10.4.2 Tri-Party Agreement Milestones for Early Phase 2 Single-Shell Tank

Retrieval .............................62

10.4.3 Phase 1 Summary and Conclusions .................... 63

11.0 PHASE 2 MISSION TECHNICAL STRATEGY $\ldots \ldots \ldots \ldots \ldots \ldots \ldots \ldots \ldots \ldots \ldots \ldots \ldots$

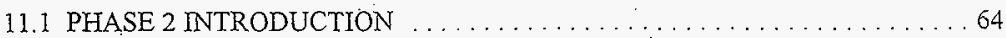

11.2 PHASE 2 MISSION TECHNICAL STRATEGIES $\ldots \ldots \ldots \ldots \ldots \ldots 6$

12.0 PHASE 2 MISSION GOALS, OBJECTIVES, AND MEASURES OF SUCCESS . . . 65

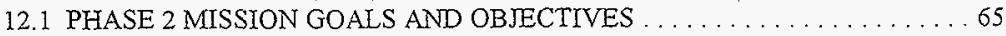

12.2 PHASE 2 MISSION MEASURES OF SUCCESS $\ldots \ldots \ldots \ldots \ldots \ldots \ldots 6$

13.0 PHASE 2 MISSION SUMMMARY ANALYSIS $\ldots \ldots \ldots \ldots \ldots \ldots \ldots \ldots \ldots \ldots \ldots$

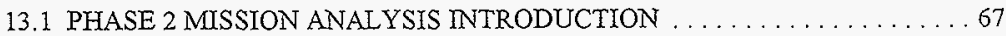

13.2 PHASE 2 LOW-ACTIVITY WASTE AND HIGH-LEVEL WASTE

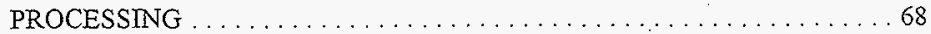

13.2.1 Phase 2 Feed Delivery Rate Requirements . . . . . . . . . . . 68

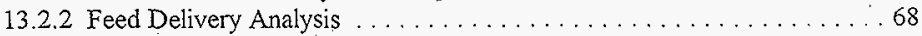

13.3 WASTE REMOVAL OPTIMIZATION RECOMMENDATIONS . . . . . . 69

13.4 MELTER CAPACITY SCALE-UP COMPARISON WITH COMMERCIAL

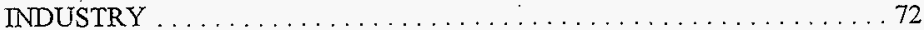

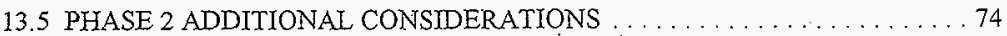

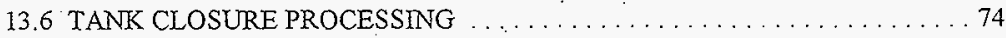

13.7 TANK WASTE REMEDIATION SYSTEM FACILITIES REQUIRED FOR THE

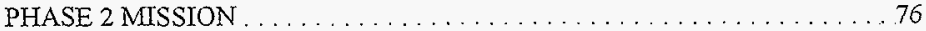

13.7.1 Phase 2 Mission - Required Facilities ................ 76

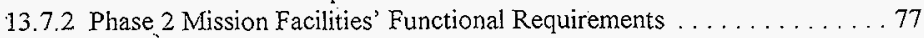

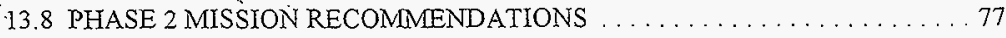

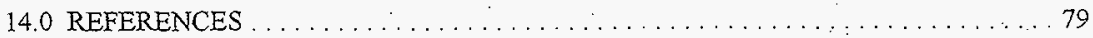




\section{APPENDIXES}

A GUIDANCE AND REQUIREMENTS TO DELIVERABLES CROSSWALK TANK WASTE REMEDIATION SYSTEM MISSION ANALYYSIS REPORT . . . . A-i

B TANK WASTE REMEDIATYON SYSTEM HISTORY $\ldots \ldots \ldots \ldots \ldots \ldots \ldots$ B-i

C TANK WASTE REMEDIATION SYSTEM EXTERNALLY IMPOSED

REQUTREMENTS $\ldots \ldots \ldots \ldots \ldots \ldots \ldots \ldots \ldots \ldots \ldots \ldots \ldots \ldots$ 


\section{LIST OF FIGURES}

1 Readiness to Proceed Document Hierarchy $\ldots \ldots \ldots \ldots \ldots \ldots \ldots \ldots \ldots \ldots \ldots \ldots \ldots \ldots \ldots$

2 Tank Waste Remediation System Boundary Diagram ................... 10

3 Single-Shell Tanks . . . . . . . . . . . . . . . . . . . . . . . 13

4 Double-Shell Tanks ....................................... 13

5 Cesium and Strontium Capsules . . . . . . . . . . . . . . . . . . . 17

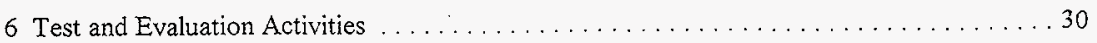

7 Tank Waste Remediation System Mission Overview ....................... 37

8 Phase 1 Immobilized Low-Activity Waste Disposal Facility - Capacity Versus Input . . . . 47

9 Tank Waste Remediation System Canister Storage Building Modules, Phase 1 - Capacity

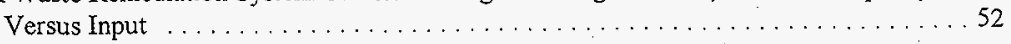

10 Tank Waste Remediation System Facility Life Cycles ................. 55

11 Phase 2 Low-Activity Waste and High-Level Waste Feed Staging . . . . . . . . . . . 70

12 Low-Activity Waste Processing - Production Improvements . . . . . . . . . . 73

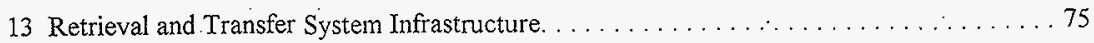




\section{LIST OF TABLES}

1 Major Tank Waste Remediation System Milestones .................... 8

2 Cesium and Strontium Capsule Requirements $\ldots \ldots \ldots \ldots \ldots \ldots \ldots \ldots \ldots \ldots \ldots \ldots$

3 Gaseous Effluents Discharge Requirements . . . . . . . . . . . . . . . . . . . 19

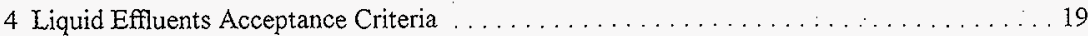

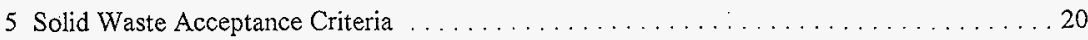

6 Immobilized Low-Activity Waste Major Final State Requirements . . . . . . . . . . . . . 21

7 Immobilized High-Level Waste Major Final State Requirements $\ldots \ldots \ldots \ldots \ldots 22$

8 Final-State Requirements Identified for Closing Single- and Double-Shell Tanks . . . . . 23

9 Tank Waste Remediation System Phase 1 Mission Goals and Objectives . . . . . . . . 34

10 Measures of Success - Tank Waste Remediation System Phase 1 End States . . . . . . 35

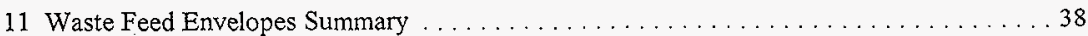

12 Major Requirements that Influence the Operating Scenario $\ldots \ldots \ldots \ldots \ldots \ldots \ldots 40$

13 Major Enabling Assumptions that Influence the Operating Scenario $\ldots \ldots \ldots \ldots \ldots .41$

14 Low-Activity Waste Source Tanks and Feed Batches .................... 43

15 Typical Low-Activity Waste Feed Delivery Batch Cycle Time for Envelope A. . . . . . . 45

16 High-Level Waste Source Tanks and Feed Batches . . . . . . . . . . . . . . . . . . 49

17 Tank Waste Remediation System Major Facilities Top-Level Functional Requirement

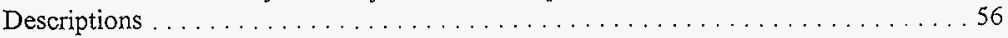

18 Summary of the Construction Projects' Scope, Schedules, and Costs . . . . . . . . . 60

19 Tank Waste Remediation System Phase 2 Mission Goals and Objectives . . . . . . . . 66

20 Measures of Success - Tank Waste Remediation System Phase 2 End States . . . . . . 67

21 Hanford Federal Facility Agreement and Consent Order Milestones . . . . . . . . . . . . 69 
HNF-SD-WM-MAR-008 Rev 3

\section{LIST OF TABLES (Continued)}

22 Number of Concurrent Retrieval Systems . . . . . . . . . . . . . . . 71

23 Comparison of Tank Waste Remediation System Planning Baseline and Example Mission Improvements Case ............................... 74

24 Phase 2 Tank Waste Remediation System Major Facilities Functional Requirements . . . 78 


\section{LIST OF TERMS}

$\begin{array}{ll}\text { BIO } & \text { Basis for Interim Operation } \\ \text { CSB } & \text { Canister Storage Building } \\ \text { D\&D } & \text { decontamination and decommissioning } \\ \text { DOE } & \text { U.S. Department of Energy } \\ \text { DST } & \text { double-shell tank } \\ \text { Ecology } & \text { Washington State Department of Ecology } \\ \text { EIS } & \text { environmental impact statement } \\ \text { EPA } & \text { U.S. Environmental Protection Agency } \\ \text { ETF } & \text { Effluent Treatment Facility } \\ \text { FY } & \text { fiscal year } \\ \text { HSTD } & \text { Hanford Site Technical Database } \\ \text { HLW } & \text { high-level waste } \\ \text { IHLW } & \text { immobilized high-level waste } \\ \text { IIAW } & \text { immobilized low-activity waste } \\ \text { LAW } & \text { low-activity waste } \\ \text { MT } & \text { metric ton } \\ \text { MUST } & \text { miscellaneous underground storage.tank } \\ \text { NEPA } & \text { National Environmental Policy Act of 1969 } \\ \text { NRC } & \text { U.S. Nuclear Regulatory Commission } \\ \text { NVOL } & \text { nonvolatile oxide less sodium and silicon } \\ \text { O\&M } & \text { Operations and Maintenance } \\ \text { OCRWM } & \text { Office of Civilian Radioactive Waste Management } \\ \text { PHMC } & \text { Project Hanford Management Contract } \\ \text { RCRA } & \text { Resource Conservation and Recovery Act of 1976 } \\ \text { RL } & \text { U.S. Department of Energy, Richland Operations Office } \\ \text { ROD } & \text { Record of Decision } \\ \text { SST } & \text { single-shell tank } \\ \text { T\&E } & \text { Test and Evaluation } \\ \text { Tri-Party Agreement } & \text { Hanford Federal Facility Agreement and Consent Order } \\ \text { TRU } & \text { transuranic } \\ \text { TSD } & \text { treatment, storage, and/or disposal } \\ \text { TWRS } & \text { Tank Waste Remediation System } \\ \text { WAC } & \text { Washington Administrative Code } \\ \text { WESF } & \text { Waste Encapsulation and Storage Facility } \\ & \end{array}$




\section{TANK WASTE REMEDIATION SYSTEM MISSION ANALYSIS REPORT}

\subsection{INTRODUCTION}

\subsection{DOCUMENT PURPOSE}

This document describes and analyzes the technical requirements that the Tank Waste Remediation System (TWRS) must satisfy for the mission. This document further defines the technical requirements that TWRS must satisfy to supply feed to the private contractors' facilities and to store or dispose the immobilized waste following processing in these facilities. To do this, it is important to describe and understand the top-level technical requirements for the TWRS Project. The current TWRS is a collection of facilities (e.g., buildings, waste storage tanks and their contents, piping) left from the prior U.S. Department of Energy (DOE) mission of nuclear weapons production and waste management activities that the DOE desires to remediate.

This document and several other documents comprise the "Readiness to Proceed" document set which has been prepared to assist the DOE in making its decision to proceed with the TWRS Phase 1 mission. Figure 1 shows the organization of these documents and their relationships. Appendix A contains a compliance matrix that indicates where in this document the DOE guidance, requirement, and directive documents are implemented.

This document uses a two-phased approach to the analysis to reflect the two-phased nature of the mission. Sections 1.0 through 7.0 discuss the TWRS Project mission as a whole and areas common to both phases. Sections 8.0 through 10.0 discuss the Phase 1 mission for TWRS, while Sections 11.0 through 13.0 discuss the Phase 2 mission.

\subsection{HANFORD SITE MISSION}

The ongoing Hanford Site environmental management mission, as stated in the Hanford Strategic Plan (RL 1996a), is to safely clean up and manage the Site's legacy wastes. To support this mission, the following major projects were established for the Hanford Site:

\footnotetext{
- TWRS

- Waste Management

- Spent Nuclear Fuels

- Facility Stabilization

- Infrastructure

- Landlord

- Richland Environmental Restoration
} 
HNF-SD-WM-MAR-008 Rev 3

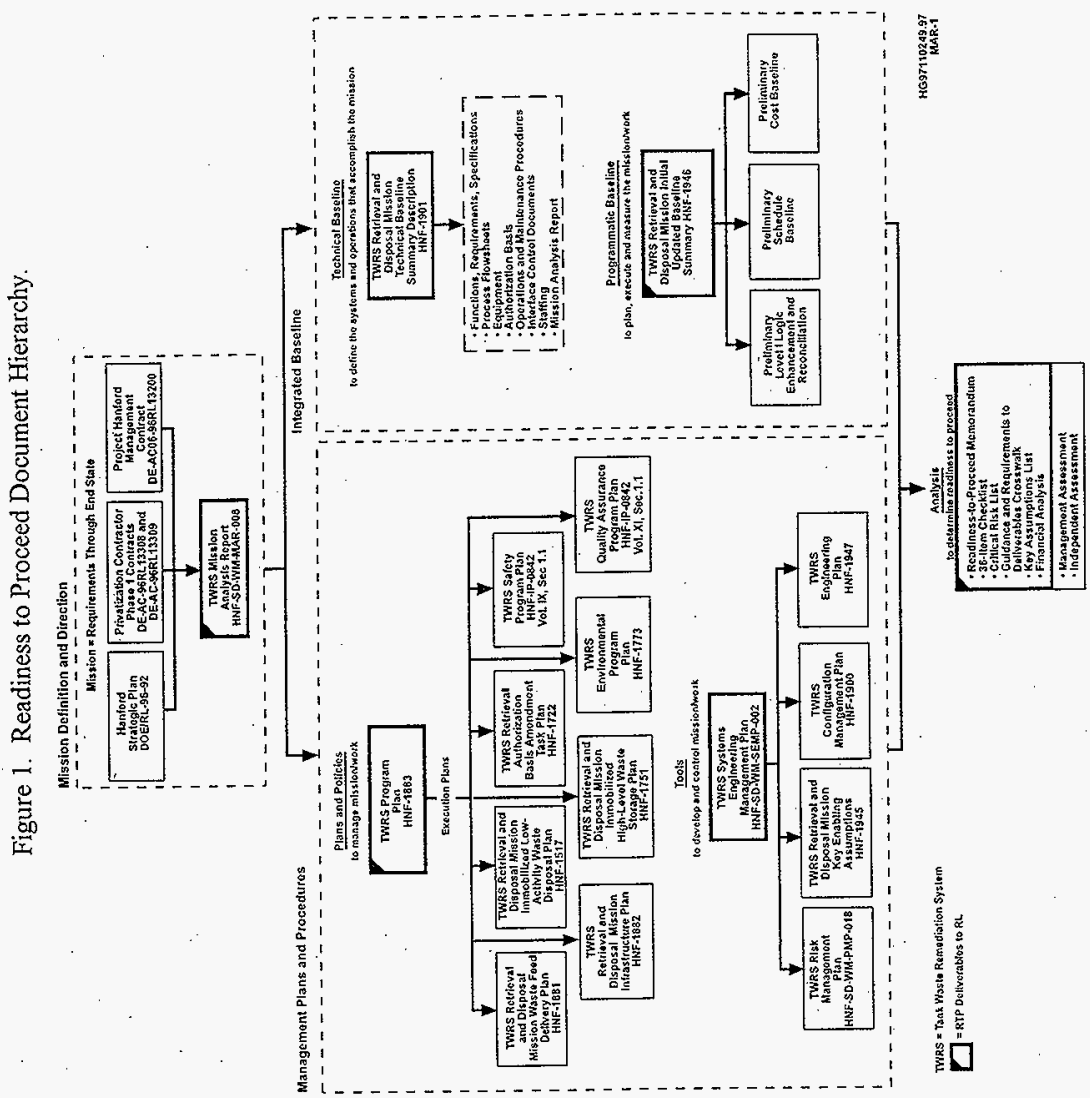




\section{- $\quad$ Solid Waste \\ - Facility Transition.}

The DOE established the TWRS Project in 1991 to support the Hanford Site environmental management mission by managing and disposing of the waste that is contained in underground storage tanks (i.e., single-shell tanks [SST] and double-shell tanks [DST]), and managing selected miscellaneous underground storage tanks (MUST) at the Site. A principal objective of the TWRS Project is to reduce and eliminate the risk to the public and the environment that results from the accumulation of about 204 million liters (54 Mgal) of mixed and high-level waste (HLW) stored in Site tanks.

Remediation of the tank waste will protect the public and the environment from exposure to radionuclides and hazardous chemicals. Protection of human health and ecological resources will be achieved by continued control of TWRS facilities and surrounding areas and restriction on uses, or by removal and/or isolation of contaminated areas in accordance with Draft Hanford Remedial Action Environmental Impact Statement and Comprehensive Land Use Plan (DOE 1996).

\subsection{MISSION SCOPE}

The TWRS Project mission scope includes the activities needed to (1) resolve safety issues; (2) operate, maintain, and upgrade the tank farms and supporting infrastructure; (3) construct, operate, and maintain facilities that are necessary for waste storage, retrieval, waste separation, waste preparation, immobilization, and disposal or shipment; (4) characterize, retrieve, pretreat, and immobilize the waste for disposal; (5) provide for the disposition of the cesium and strontium capsule contents; (6) provide disposal of immobilized low-activity waste (ILAW) onsite; $(7)$ provide interim storage of immobilized high-level waste (IHLW) until it is shipped to the national geologic repository; and (8) provide for the closure and decontamination and decommissioning (D\&D) of TWRS facilities and post-closure monitoring.

\subsection{TANK WASTE REMEDLATION SYSTEM HISTORY}

The TWRS bears the legacy of the original Hanford Site weapons production mission. During the production mission, the concern was to safely store the by-product waste that resulted from the production effort. Over the years, the Hanford Site mission evolved to today's mission of Site cleanup, which requires remediation of the wastes stored in tanks in the 200 Areas of the Site. Appendix B contains a brief history of TWRS and describes how the TWRS Project mission has evolved. 


\subsection{TANK WASTE REMEDLATION SYSTEM PROBLEM}

\subsection{PROBLEM BACKGROUND}

In 1996 , the DOE proposed a strategy to retrieve and treat the wastes in the Hanford Site's HLW tanks using a combination of existing DOE contractors and privatized contractor teams. The DOE divided treatment of the tank wastes into a demonstration phase, called Phase 1 , and a full-scale production mode, called Phase 2 . Phase 1 was planned to last 10 to 14 years and would process $6 \%$ to $13 \%$ of the total Hanford Site tank waste.

In Phase 1, the Project Hanford Management Contract (PHMC) Team would upgrade the associated tank farms and transfer piping, move the waste feed to staging tanks, adjust feed as necessary to meet specifications, and deliver the feed to the private contractors. The private contractors would treat and immobilize the wastes and transfer the immobilized wastes to the DOE for storage and disposal.

The current DOE strategy is to procure retrieval and treatment services from private contractors during Phase 2. The remaining SST waste that was not processed during Phase 1 and the waste remaining in the DSTs will be processed during Phase 2 . The DOE plans to make critical decisions during fiscal year (FY) 1998 regarding the overall readiness of the PHMC Team and the private contractors to proceed with the demonstration phase.

\subsection{PROBLEM DEFINITION}

Existing SST storage systems do not comply with the State of Washington laws applicable to tank storage systems (Washington Administrative Code [WAC] 173-303-640) that implement the Resource Conservation and Recovery Act of 1976 (RCRA) treatment, storage, and/or. disposal (TSD) requirements. The Washington State Department of Ecology (Ecology), the U.S. Environmental Protection Agency (EPA), and the U.S. Department of Energy, Richland Operations Office (RL) have negotiated the Hanford Federal Facility Agreement and Consent Order (Tri-Party Agreement) (Ecology et al. 1996), a compliance agreement to impose cleanup objectives for the remediation of tank waste that remains in the SSTs and to establish interim status for TWRS facilities and systems. Consequently, under the terms of the Dangerous Waste portion of the Hanford Facility RCRA Permit (Ecology and EPA 1994), the SSTs will not be permitted. Instead, those SST systems will be closed under applicable provisions of WAC $173-303-610$.

Double-shell tanks continue to receive new waste from TWRS tank farm operations and other Site programs. Double-shell tank space is limited and will be inadequate for future storage capacity requirements unless efforts are made to treat and immobilize DST waste.

Indefinite storage of radioactive, hazardous, and mixed wastes in underground storage tanks and in cesium and strontium capsules at the Hanford Site poses unacceptable long-term 
risks to the public, the workers, and the environment. Sixty-seven of the 149 SSTs have leaked waste to the soil beneath the tanks. The remaining SSTs have the potential to develop leaks to the soil. Further, the potential exists for airborne releases from a catastrophic dome structural collapse or from a failure of ancillary equipment.

The cesium and strontium capsules are stored onsite at the Waste Encapsulation and Storage Facility (WESF). This facility contains a large component of the radioactive waste inventory at the Hanford Site and it was not designed for long-term storage of the cesium and strontium capsules.

The annual mortgage costs to operate and maintain these aged storage systems are high and will continue to escalate as these systems age. These costs can be mitigated by closure of the tank farms and by disposal of the cesium and strontium capsules.

\subsection{TANK WASTE REMEDLATION SYSTEM MAJOR ISSUES OVERVIEW}

Issues at the mission level concern those questions relating to technology, regulations, required resources, and future conditions that yield requirements considered critical to the timely completion of the mission. Issues, as they are identified, will be managed as risks with management and operations actions and kept within a managed profile. Assumptions associated with such issues are made as necessary to support long- and short-range planning. The enabling assumptions become a non-validated requirement and identify a means to proceed with the mission, albeit at some additional risk. Management processes will be emplaced to ensure that the risks are managed. The Tank Waste Remediation System Retrieval and Disposal Mission Key Enabling Assumptions (Baldwin et al. 1998) contains a list of key enabling assumptions for the Phase 1 mission. The Risk Lists associated with the Tank Waste Remediation System Risk Management Plan (Zimmerman 1998) contain a listing of the major risks associated with the TWRS Phase 1 mission and a plan is presented to manage these risks. A detailed list of enabling assumptions for Phase $\mathrm{IB}$ can be obtained from the Enabling Assumptions.Management and Control System Database (EAMCS n.d.) maintained by the Lockheed Martin Hanford Corporation. This database is maintained in conjunction with the Hanford Site Technical Baseline contained in the Hanford Site Technical Database (HSTD [HSTD n.d.]). Phase 2 enabling assumptions can be obtained from the HSTD.

\subsection{MISSION STATEMENT}

The TWRS Project will provide safe storage and management of the legacy and new waste, retrieval and disposal of the waste, D\&D of TWRS facilities, and closure of TWRS sites. 


\subsection{TANK WASTE REMEDIATION SYSTEM MISSION}

The TWRS retrieval and disposal mission is complex and will occur in two phases. Phase 1 retrieval and disposal activities will continue to safely store TWRS remaining tank wastes, demonstrate the capability to retrieve waste from DSTs and SSTs, immobilize and dispose the low-activity waste (LAW) and immobilize and store the HLW from the DSTs, and safely store retrieved SST waste in the DSTs until Phase 2 commences.

Phase 2 retrieval and disposal efforts will (1) continue to safely store TWRS tank waste until removal; (2) completely remove tank wastes, process the cesium and strontium capsules, immobilize LAW and HLW, dispose of the LAW, and provide the interim storage and subsequent transfer of IHLW to the national geologic repository; (3) close the tank farms, and clean up, decontaminate, and decommission the unneeded facilities; and (4) maintain long-term surveillance of the LAW disposal facilities.

\subsection{MISSION MANAGEMENT APPROACH}

To accomplish the TWRS Project mission, a phased approach is being implemented in accordance with the "Record of Decision for the Tank Waste Remediation System, Hanford Site, Richland, WA" (TWRS EIS ROD) (62 FR 8693). Various levels of mission execution have been identified in logic diagrams that relate to schedules for accomplishing the mission. The TWRS Program Logic diagram located in the Tank Waste Remediation System Program Plan (Freeman 1998) shows the overall order of execution of the mission. The TWRS Program Logic diagram also shows the major tasks that are necessary to complete the TWRS Project mission and the relationships between these major tasks.

Execution of the TWRS Project mission has been divided into the following ten management areas:

- Waste Characterization

- Safety Issue Resolution

- Tank Farms Operations

- Waste Retrieval

- Process Waste Support

- Privatization Phase 1

- Privatization Phase 2

- Privatization Infrastructure

- Immobilized Tank Waste Storage and Disposal

- TWRS Management Support.

Details of these management areas can be found in the Tank Waste Remediation System Fiscal Year 1998 Multi-Year Work Plan WBS L.I (Lenseigne 1997). 


\subsection{TANK WASTE REMEDIATION SYSTEM BOUNDARY AND INTERFACES}

\subsection{MISSION TIMING}

Based on information received from the DOE, Phase 1 has two parts: developmental (Phase 1A) and demonstration (Phase 1B). Phase 1A has commenced and will establish the . technical, operational, regulatory, and financial elements required by the privatized facilities ([RL 1996b, RL 1996c]). Phase 1B is scheduled to commence in May 1998 and will establish the facilities and infrastructure to immobilize LAW and HLW. Initial waste feed delivery to the private contractors is scheduled to begin in June 2002. An extension period, if invoked for the private contractors during Phase $1 \mathrm{~B}$, will begin after minimum quantities of waste are processed (June 2007 or June 2008 , depending on the contract award) and end in June 2011.

Phase 2 is currently scheduled to commence on January 1, 2011, when Phase 2 retrieval activities begin. However, Phase 2 activities will have to begin much earlier if the recommendations to modify the immobilization plant capacity are implemented (see Sections 10.0 and 13.0). Phase 2 LAW and HLW processing will begin in the last quarter of 2011 (Kirkbride et al. 1997). The PHMC Team will need to begin SST retrieval much earlier than 2011 to meet the Tri-Party Agreement (Ecology et al. 1996) milestone for SST retrieval.

Table 1 summarizes the major programmatic milestones that structure the program. These milestones are based on the Tri-Party Agreement and amendments and incorporate the phased privatization approach.

\subsection{PROGRAMMATIC INTERFACES}

Stakeholders are an important programmatic interface. They are interested or engaged in influencing the future of the Hanford Site as identified in the Final Report: Hanford Tank Waste Task Force (HTWTF 1993) and Public Values Related to Decisions in the Tank Waste Remediation System Program (Dirks and VonWinterfel 1994).

Stakeholder values of highest importance include the following.

- Make progress with the cleanup activities.

- Protect public and worker health and safety.

- Protect the Columbia River.

- Clean up to the level necessary to enable future use options to occur. 
- Capture economic development opportunities locally.

- Protect the rights of the Native Americans.

- Ensure compliance.

- Reduce cost

- Use a systems approach.

- Allocate funds to high-priority items.

- Do not rely on unproven technologies, but use technological innovations as they become available.

Table 1. Major Tank Waste Remediation System Milestones.

\begin{tabular}{|l|l|}
\hline \multicolumn{1}{|c|}{ Milestone } & \multicolumn{1}{c|}{ Date } \\
\hline Initiate LAW Immobilization (Phase 1)* & June 2002 \\
\hline Initiate HLW Immobilization (Phase 1) (M-51-03) & December 2009 \\
\hline Complete SST Waste Retrieval (M-45-05) & September 2018 \\
\hline Complete Closure of all SSTs (M-45-00) & September 2024 \\
\hline Complete LLW Immobilization (M-60-00) & December 2024 \\
\hline Complete HLW Immobilization (M-51-00) & December 2028 \\
\hline
\end{tabular}

*RL, 19966, Lackheed Mantin Adwanced Environmental Systems Private Contract, DE-AC06-96RL13309, U.S. Department of Energy, Richland Operations Office, Richland, Washington; and RL, 1996c, British Nuclear Fuels Laboratory Private Contract, DE-AC06-96RL13308, U.S. Department of Energy, Richland Operations Office, Richland, Washington.

Source: Ecology, EPA, and DOE, 1996. Hanford Federal Facility Agreement and Consem Order, 2 vol., Washington State Department of Ecology, U.S. Environmental Protection Agency, and U.S. Department of Energy, Olympia, Washington.

HLW $=$ high-level waste.

$L A W=$ low-activity waste.

LLW $=$ low-level waste.

SST $=$ single-shell tank.

The TWRS organizations interface with the other Hanford Site major project organizations (e.g., Spent Nuclear Fuels, Waste Management) to transmit data on waste and materials that are to be transferred, to establish schedules, and to relay processing status. The Project Hanford Management Contract (PHMC) (RL 1996d) requires status, plans, reports, and identification of program needs, and provides control, guidance, and authorization to perform work. In addition, the private contractors will have major programmatic interfaces with the TWRS Project. 
Because TWRS is a subsystem of the larger Hanford Site cleanup system, TWRS Project mission activities must be fully integrated with the other Site cleanup missions to meet the overall goals and objectives of the Site mission.

Outside the Hanford Site, programs and agencies (e.g., Ecology, U.S. Nuclear Regulatory Commission [NRC], EPA, Office of Civilian Radioactive Waste Management [OCRWM], Occupational Safety and Health Administration, Washington State Department of Health, repository programs, Defense Nuclear Facilities Safety Board, and Congress) interface with TWRS via regulations, guidance, acceptance criteria for final state of wastes, and approval of resources.

\subsection{INTERFACES}

Figure 2 shows the TWRS boundary diagram. The major offsite interface for TWRS is the national geologic repository. The TWRS assumes that the national geologic repository will accept IHLW in the future. Acceptance criteria for a "standard" HLW form and canister have been established. Acceptance criteria for other potential waste forms from TWRS are under development. Other interfaces exist for the shipment of hazardous waste to offsite facilities.

The primary onsite interfaces for TWRS include the Canister Storage Building (CSB), the 242-A Evaporator, the Treated Effluent Disposal Facility, the Effluent Treatment Facility (ETF), the WESF, the 100 Area facilities, the 200 Area facilities (not related to TWRS), the 300 Area facilities, the 400 Area facilities, the Analytical Laboratories, the Solid Waste Disposal facilities, and the 90-day hazardous waste storage facility. Basic infrastructure interfaces include those for sewer, water, electrical, sanitation, and transportation facilities.

Onsite interfaces must accommodate receipt of new tank waste, cesium and strontium capsules from the WESF, raw materials, analytical laboratory waste samples, and transport of. waste products to and from the CSB (IHLW), modified grout vaults (ILAW), and to future facilities. Section 5.0 contains more details on the interfaces for TWRS.

The TWRS Project mission includes waste storage and waste retrieval, waste separation and preparation, immobilization of waste for storage of IHLW, disposal of ILAW onsite, closure of 18 tank farms, and the disposal of the cesium and strontium capsules. During Phase I of the TWRS acquisition strategy, key interfaces within TWRS will be required to provide infrastructure support and waste feed materials to the private contractors and to receive process by-products and ILAW/IHLW from private contractors. The private contracts contain requirements for interfaces with the privatization facilities. During Phase 2 of the TWRS acquisition strategy, additional interfaces will be required to accommodate additional private contractor treatment facility capacity and additional TWRS storage and disposal facilities.

The TWRS requires interfaces for liquid effluent transport to the ETF and disposal facilities onsite. The TWRS also will require interfaces for solid waste disposal onsite and offsite. 
Figure 2. Tank Waste Remediation System Boundary Diagram.

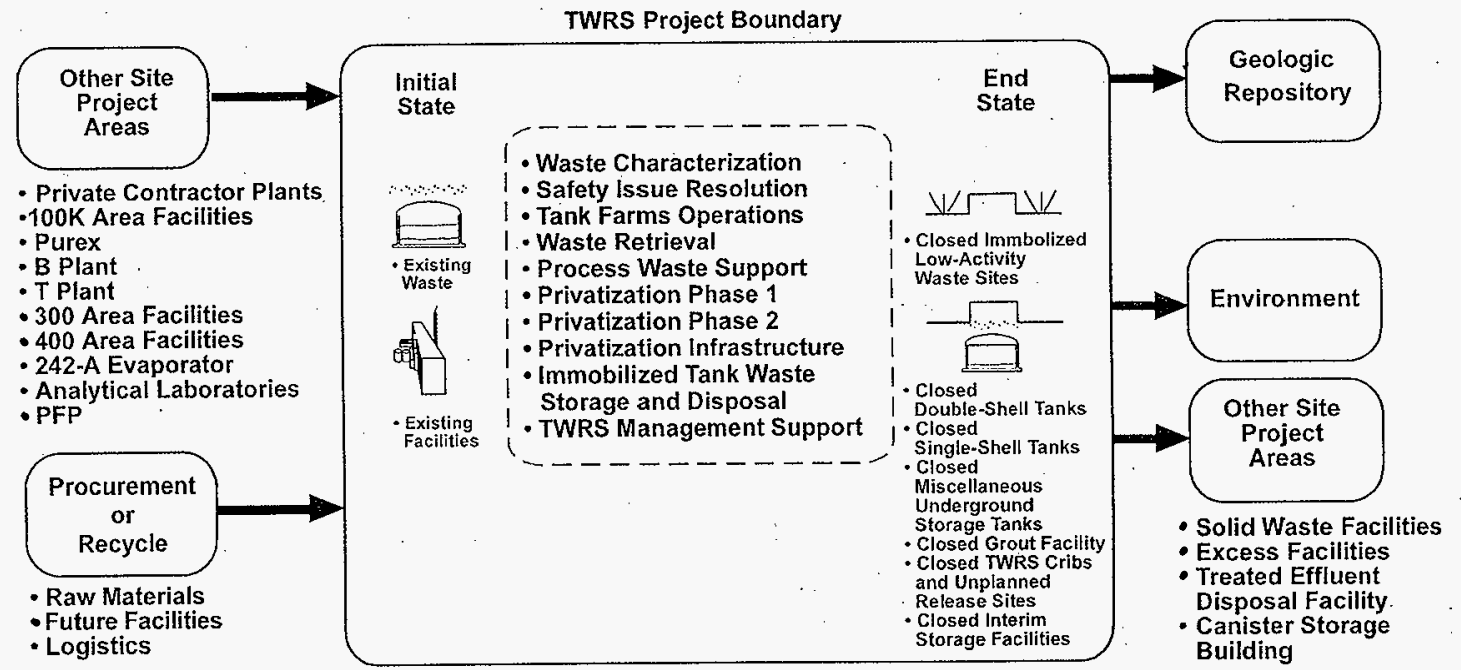


The work force at the Hanford Site provides TWRS with mature and compliant Operations and Support organizations. Operations, maintenance, engineering, and other support staff are fully trained. Management systems and procedures are in place and ready to support the Phase 1B mission. Activities similar to those necessary to support Phase 1B, e.g., waste sampling, waste characterization, waste transfers, and emergency response, are conducted routinely. The maturity of the Operations programs is supported by favorable trends in performance indicators, conclusions and trends from a series of independent assessments, operational readiness reviews, and a mature nuclear safety Authorization Basis.

Physical interfaces where waste retrieval will take place must comply with the limiting conditions for operation of the TWRS Authorization Basis, which is currently represented in the Tank Waste Remediation System Baisis for Interim Operation (BIO) (FDH 1997), the associated technical safety requirements, and related documents. The Authorization Basis provides the safety Authorization Basis for the PHMC portion of the TWRS Project mission. It is expected that the mission can be accomplished with amendments to this Authorization Basis as required to accommodate facility modifications, new facilities, and changed operations.

\subsection{TANK WASTE REMEDIATION SYSTEM INITIAL STATES, INPUTS, OUTPUTS, END STATES, AND ASSOCIATED REQUTREMENTS}

\subsection{APPLICABLE SOURCES FOR EXTERNALLY IMPOSED REQUTREMENTS}

Externally imposed requirements include applicable federal, state, and local legislation, as well as associated statutes, regulations, codes, and standards. Tables $\mathrm{C}-1$ through $\mathrm{C}-3$ in Appendix $\mathrm{C}$ contain the constraint requirements identified for the TWRS Project mission. Tables $\mathrm{C}-4$ through $\mathrm{C}-7$ contain requirements obtained from four major sources of requirements for the TWRS Project mission. These major source documents are the Hanford Strategic Plan (RL 1996a), the Draft Hanford Remedial Action Environmental Impact Statement and Comprehensive Land Use Plan (DOE 1996), the Project Hanford Management Contract (PHMC) (RL 1996d), and the Tri-Party Agreement (Ecology et al. 1996).

In addition to federal regulations and applicable WACs listed in Appendix $\mathrm{C}$, the Project Hanford Management Contract (PHMC) (RL 1996d) adds DOE Orders and Directives that may be applicable to work and activities conducted or accomplished by TWRS. The subcontract between the Lockheed Martin Hanford Corporation and Fluor Daniel Hanford, Inc. (FDF 1996) further qualifies these requirements for applicability to TWRS. 


\subsection{TANK WASTE REMEDIATION SYSTEM INITIAL STATES}

This section describes certain initial conditions of the TWRS facilities. The tank farms operate under an approved Authorization Basis that requires a trained work force familiar with appropriate procedures and certified to operate and maintain the facility.

\subsubsection{Single-Shell Tanks and Double-Shell Tanks}

More than $99 \%$ of the existing tank waste is stored in 133100 -series SSTs, 16200 -series SSTs, and 28100 -series DSTs. Less than $1 \%$ of the waste is stored in MUSTs and associated pipelines with a minor amount stored at the Analytical Laboratory. Figure 3 illustrates the basic structure of these 100-series SSTs, although the data in the figure apply to both 100-and 200-series SSTs. The 200-series SSTs are much smaller than the 100-series SSTs with capacities typically around $208,000 \mathrm{~L}(55 \mathrm{kgal})$. Figure 4 illustrates the basic structure for the DSTs. The data in the figure apply to the DSTs as a whole.

Waste storage capacity is required for current waste inventories and new waste from retrieval, disposal operations, and other Site activities. The integrity of these tank structures and consequently the tank's availability can affect the schedule for completing the TWRS Project mission. None of the 28 DSTs are known to have leaked, 82 SSTs have not been determined to be leaking, and 67 SSTs are assumed to have previously leaked approximately 2.3 million to 3.4 million liters (600 to $900 \mathrm{kgal})$ and $1.2 \times 10^{13}$ to $4.2 \times 10^{13} \mathrm{~Bq}(330$ to $1.130 \mathrm{kCi})$ of ${ }^{137} \mathrm{Cs}$ into the surrounding soil (Hanlon 1997). The average per tank leakage is approximately 34,000 to $49,000 \mathrm{~L}$ ( 9 to $13 \mathrm{kgal}$ ). The largest leakage is estimated to be $435,000 \mathrm{~L}$ (115 kgal).

\subsubsection{Miscellaneous Underground Storage Tanks}

The TWRS Project also contains MUSTs used (1) as catch tanks, neutralization tanks, settling tanks, and receiving vault tanks; (2) for waste handling in the tank farm system; (3) for uranium recovery support; or (4) to support waste handling from a specific facility. The MUSTs vary in capacity from about $3,600 \mathrm{~L}$ ( $955 \mathrm{gal})$ to $190,000 \mathrm{~L}$ ( $50 \mathrm{kgal}$ ). The TWRS has programmatic responsibility for 48 MUSTs.

Of the 48 MUSTs, 36 are associated with inactive facilities (Brevick 1997 and Hanford Site Waste Information Data System [WIDS] [WIDS n.d.]). These MUSTs have been removed from service, most have had their inlet lines blanked, and most monitoring activities have been terminated. Many of the tanks contain radioactive chemical sludge and a liquid heel. The tanks are near processing plants, pipeline diversion boxes, cribs, and reverse wells.

The remaining 12 active MUSTs support waste transfers and storage within TWRS (Hanion 1997, WIDS n.d.). 
Figure 3. Single-Shell Tanks.

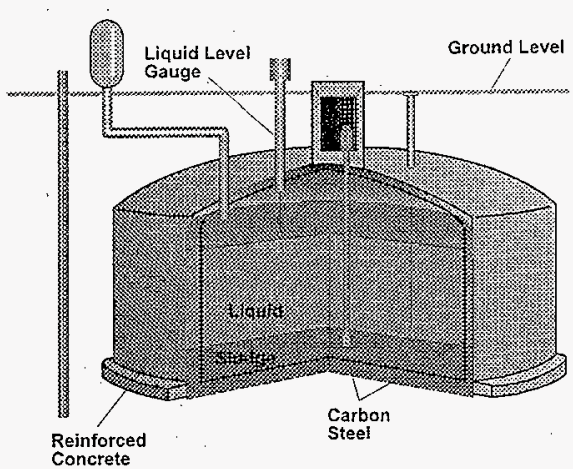

- 149 Tanks Constructed 1943-64

- $208 \times 10^{3}$ to $3.8 \times 10^{6}$ iiters Capacity (55 kgal to 1 Mgal)

- No Waste Added to Tanks Since 1980

- Tanks Currently Contain: $\sim 132.5 \times 10^{6}$ liters (35 Mgal) of Salt Cake, Sludge, and Liquid

- 67 Have Leaked $\sim 2.3$ to $3.4 \times 10^{6}$ liters $(600-900 \mathrm{kgal})$

Concrete

Source: Hanlon B. M., 1997, Waste Tank Summary Report for Month Ending July 31, 1997, HNF-EP-0182-112, prepared by Lockheed Martin Hanford Corporation for Fluor Daniel Hanford, Inc., Richland, Washington.

Figure 4. Double-Shell Tanks.

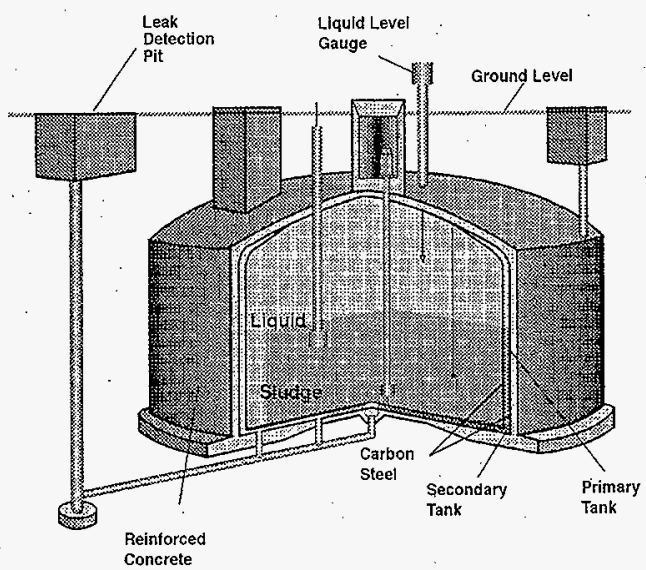

- 28 Tanks Constructed Between 1968-86

$\therefore-3.8$ to $4.3 \times 10^{6}$ fiters (1 to 1.14 Mgal) Capacity

- Tanks Currently Contain $\sim 72 \times 10^{6}$ liters (19 $\mathrm{Mgal}$ ) of Mostly Llqulds (Also Sludges and Salts)

- None Have Leaked

Source: Kanlon, B. M., 1997, Wasto Tank Summary Report for Month Ending Jufy 31, 1997, HNF.EP-0182-112, prepared by Lockheed Martin Hantord Corporation for Fluor Daniel Hanford, Inc., Fichland, Washington. 


\subsubsection{Existing Tank Waste}

Tank waste includes the contents of 149 SSTs, 28 DSTs, and 48 MUSTs that are assigned to the TWRS Project. The 222-S Laboratory and the 340 Building Laboratory hold small amounts of additional waste. Approximately 204 million liters (54 Mgal) of radioactive $\left(228 \times 10^{6} \mathrm{Ci}\right)$ and hazardous RCRA wastes (Kupfer et al. 1997) are stored at the Hanford Site in the TWRS facilities.

Sodium salts represent the primary waste constituent and dominate the solids volume of tank waste. The nitrate ion $\left(\mathrm{NO}_{3}{ }^{-}\right)$, primarily as sodium nitrate, constitutes the largest volume of hazardous chemicals in the tanks. Nitrates in the tanks and in existing soil and groundwater contamination dominate the noncarcinogenic hazard impact for long-term groundwater risk (Hesser et al. 1995). Uranium is the most prevalent heavy metal and radioactive element but its chemical and radiological toxicities are relatively low. Highly mobile chromium in the waste is a heavy metal of concern in groundwater contamination (Boothe 1995). The inventory of hydroxide ion $\left(\mathrm{OH}^{-}\right)$, primarily as sodium hydroxide, is used to control the in-tank chemical conditions. Cesium-137 and ${ }^{90} \mathrm{Sr}$ (and equilibrium decay daughters), along with internally deposited plutonium (Boothe 1995), dominate the current total waste activity and are the radioisotopes of concern for an external dose in accident analyses and worker exposure in the near term.

A detailed source for tank content information is the Standard Inventories of Chemicals and Radionuclides in Hanford Site Tank Wastes (Kupfer et al. 1997). This reference includes details about the inventory of radioactive and nonradioactive constituents contained in the SSTs and DSTs. Tables ES-1 and ES-2 of the Standard Inventories of Chemicals and Radionuclides in Hanford Site Tank Wastes (Kupfer et al. 1997) establish best-basis global standard inventories for nonradioactive and radioactive tank waste inventory in metric tons (MT).

\subsubsection{Tank Equipment and Other Waste Materials}

Many SSTs contain equipment and materials in addition to the typical waste sludge, salt cake, and liquids. These materials were discarded before November 1980 as part of storage and transfer operations, full-scale experiments, and development activities. Discarded equipment included large installed hardware (e.g., airlift circulators, thermocouple trees, steam coils, and sluicers). Materials added to some tanks include experimental fuel elements, cobalt slugs, diatomaceous earth, Portland cement, and other miscellaneous items such as sample bottles. Some DSTs contain installed equipment (e.g., airlift circulators and thermocouple trees) to support storage operations. However, non-equipment material additions to DSTs have been limited to typical waste chemicals and new waste. 


\subsubsection{Other Tank Waste Remediation System Facilities}

In addition to tank structures, TWRS includes legacy facilities, such as the inactive evaporator, TWRS cribs, unplanned release sites, contaminated soil sites, and various support buildings which must be remediated, decontaminated and decommissioned, or made available for re-use.

The facilities to support storage and transfer of tank waste include the waste unloading . station, lift pump stations, encased transfer lines, diversion boxes, vaults, and valve pits.

The TWRS contains transfer system elements that are active (in use) and inactive (no longer in service). Transfer lines exist between many tank farms within the 200 East and 200 West Areas.

A cross-site transfer system is in place to support tank waste transfer between the 200 East and 200 West Areas. The old cross-site transfer system has one proven good transfer line and one of questionable integrity. Project W-058 recently completed an additional cross-site transfer line. These cross-site transfer lines are expected to be adequate for Phase 1 retrieval activities.

\subsubsection{Phase 2 Mission - Tank Waste Remediation System Initial States}

Phase 2 initial states are much the same as Phase 1 with the following exceptions: (1) up to 12 of the DSTs will have had their waste removed to support the Phase 1 demonstration and to free up space for the balance of the retrieval activities (Kirkbride et al. 1997), (2) up to 34 of the SSTs will have been retrieved (Kirkbride et al. 1997), (3) the CSB will have received the treated (glassified) HLW and the dry powdered cesium canisters from the private contractors' plants, and (4) the ILAW Disposal Facility will have received the treated ILAW. from the private contractors' plants.

\subsection{TANK WASTE REMEDIATION SYSTEM INPUTS AND OUTPUTS}

\subsubsection{New Tank Waste}

The DST System will continue to receive small amounts of new waste that are generated primarily from other Hanford Site activities and from tank farm operations. The primary sources of this new waste are waste solutions generated from the following:

- Miscellaneous tank farm maintenance

- $\quad$ SST (salt well pumping) operation

- SST retrieval activities

- Surveillance of the Plutonium-Uranium Extraction facility

- Surveillance and deactivation of the Plutonium Finishing Plant

- 222-S Analytical Laboratory activities 


\section{HNNF-SD-WM-MAR-008 Rev 3}

- T Plant activities

- B Plant activities

- WESF activities

- 340 Facility activities

- 327 Facility activities

- $\quad 325$ Facility activities

- $\quad 324$ Facility activities

- 400 Area deactivation activities

- 242-A Evaporator and tank line flushes

- Dilution of existing tank waste for retrieval, waste separation, and preparation

- K Basin operations and decontamination operation

- $\quad$ 105-F Basin and 105-H Basin decontamination activities

- Private contractors' plants (see Section 5.3.5).

New waste additions may occur from other future Hanford Site mission activities, such as liquid wastes from the following:

- Future facility D\&D activities

- Future solid waste treatment facilities

- Burial trench leachate collection systems

- Groundwater treatment activities.

Actual waste streams depend on the final configuration selected for waste generator systems and the results of tradeoff studies comparing disposal alternatives. A decision to include these wastes in TWRS will be considered on a case-by-case basis.

\subsubsection{Cesium and Strontium}

The cesium and strontium capsules and their contents will be inputs to the Phase 2 mission facilities. The cesium and strontium capsules are currently stored onsite at the WESF and at the 324 Building. These capsules will be consolidated at the WESF. The lifetime of these capsules is indeterminate as indicated by a capsule failure at an offsite location. The capsule failure investigation noted important differences between offsite and WESF operations (e.g., the WESF thermal cycles are minimal, if any) that tended to reduce the concern for failure of capsules stored at the WESF. However, a specific failure mechanism could not be verified (DOE 1990).

The TWRS EIS ROD (63 FR 8693) established that the DOE has decided to defer the decision on the disposal of the cesium and strontium capsules for up to 2 years. The Hanford Site Facility Transition Project is responsible for these capsules and retains responsibility for their ongoing, safe, and environmentally acceptable storage until a decision is made on their disposal. If the decision is made not to use the capsules for an alternative use, and the option of processing and disposal is selected, TWRS will be tasked to process the 1,929 capsules that are stored at the Hanford Site. The DOE will prepare a supplemental ROD to modify the deferred decision of the TWRS EIS ROD (Claghorn 1997, Taylor 1997a). Figure 5 shows a summary of the capsule data. 
Figure 5. Cesium and Strontium Capsules.
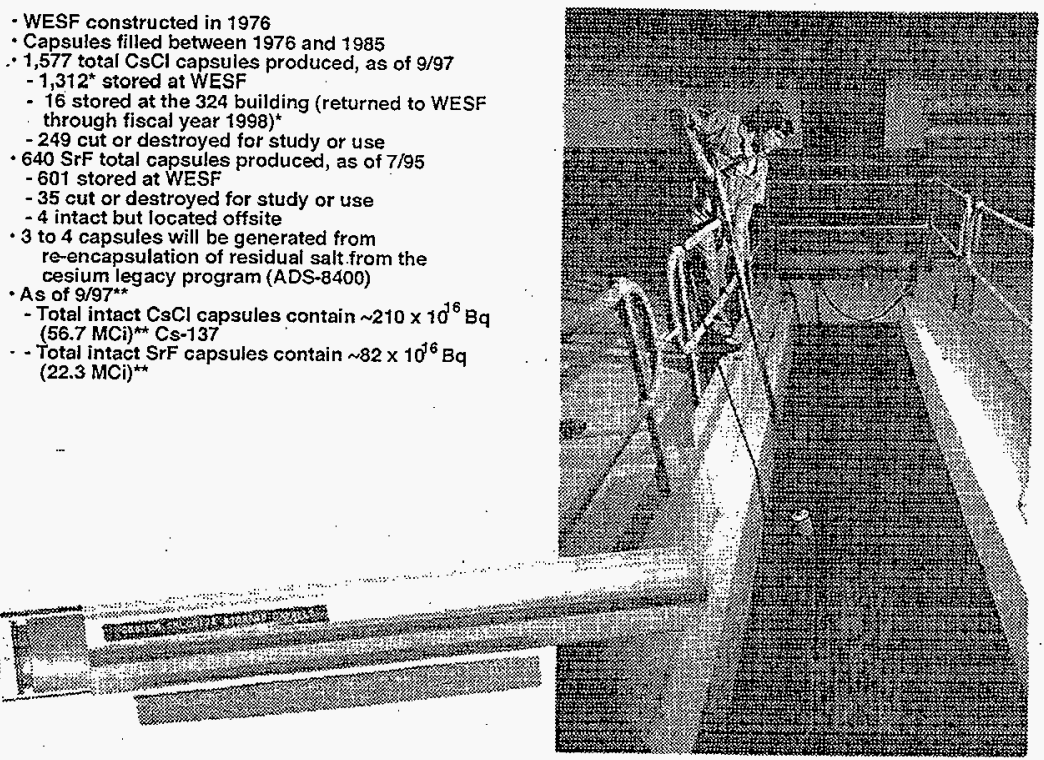

- Source: Hedquist, K. A., 1997, Prolect Management Plan for WESF ${ }^{127} \mathrm{CS}$ and ${ }^{90} \mathrm{Sr}$ Capsulo Storago, HNF-SD-WM-PMP-025, Rev. 0, prepared by B\&W Hantord Company for Fluor Daniel Hanford, inc., Fichland, Washington.

** Source: Kupfor, M. J., A. L. Boldt, B. A. Hlgley, K. M. Hodgson, L. W. Shelton, and R. A. Watrous (LMHC), S. L. Lambert and D. E. Place (SESC), R. M. Orme (NMC), G. L. Borsheim (Borsheim Associates), N. G. Golton (PNNL), M. D. LeClair (SAIC), R. T. Wisward (Meler Assoclates), and W. W. Schulz ( $W^{2} S$ Corporaton), 1987, Standard invontorlos of Chemicals and Radlonuclldes in Hanford Sto Tank Wastes, HNF-SD-WM-T1-740, Rev. 1 , prepared by Lockheed Martin Hanford Corporation for Fluor Daniel Hanford, Ine., Richland, Washington.

WESF $=$ Waste Enoapsulation and Storage Facility

A recent directive from RL (Taylor 1997a) directs the PHMC Team to assume that the contents of the cesium and strontium capsules will be processed with HLW feed. This approach also will be consistent with applicable components of Milestone M-33 (and changes, M-92-0 through M-92-05) of the Tri-Party Agreement (Ecology et al. 1996). Table 2 contains requirements relating to the cesium and strontium capsules. 
Table 2. Cesium and Strontium Capsule Requirements.

\begin{tabular}{|l|l|}
\hline \multicolumn{1}{|c|}{ Requirement } & \multicolumn{1}{|c|}{ Requirement classification or citing } \\
\hline DOE Order $5820.2 \mathrm{~A}^{\mathrm{a}}$ & Radioactive waste classification \\
\hline $40 \mathrm{CFR} 261$ Subparts $\mathrm{C}$ and $\mathrm{D}^{b}$ & Hazardous waste definitions \\
\hline $10 \mathrm{CFR} 60.135^{\mathrm{c}}$ & Criteria for the waste package and its components \\
\hline
\end{tabular}

'DOE Order 5820.2A, Radioactive Waste Kanagement, U.S. Deparment of Energy, Washington, D.C., 1988.

"40 CFR 261, 1996, "Identification and Listing of Hazardous Waste," Code of Federal Regulations.

"10 CFR 60, 1992, "Disposal of High-Level Radioactive Wastes in Geologic Repositories," Code of Federal Regulations. CFR $=$ Code of Federal Regulations. DOE = U.S. Deparment of Energy.

\subsubsection{2-A Evaporator Feed}

Waste volume control is achieved by evaporation. During Phase 1 , dilute liquid wastes will be transferred to an available holding tank, sampled, and transferred to the $242-A$ Evaporator feed tank (AW-102) and, subsequently, to the 242-A Evaporator for boil down until the maximum waste volume reduction is achieved (Strode and Boyles 1997).

\subsubsection{Containerized Dry Cesium Powder}

Cesium will be separated by the LAW Plant - Phase 1, packaged into canisters, and sent to the TWRS CSB modules, Phase 1, for interim storage. The private contracts (RI 1996b, RL 1996c) and Table 2 have applicable requirements.

\subsubsection{Other Radioactive Wastes}

Technetium will be separated by the LAW Plant - Phase 1 and returned to the DST System. Strontium and transuranic (TRU) wastes will be separated by the LAW Plant - Phase 1 and returned to the DST System. These waste streams must meet the acceptance requirements for the DST System. The private contracts (RL 1996b, RL 1996c) have applicable requirements, as defined by the DOE.

\subsubsection{Gaseous Effluents}

The TWRS releases gaseous effuents to the environment after appropriate treatment and monitoring. The release of nonradioactive air pollutants is regulated under the authority of Ecology primarily through WAC $173-400$ and WAC $173-460$. The release of radioactive air pollutants is regulated under WAC 246-247. Appropriate permits will be obtained for new releases associated with new or modified facilities. Table 3 lists specific requirements for gaseous effluents. 
Table 3. Gaseous Effluents Discharge Requirements.

\begin{tabular}{|l|l|}
\hline \multicolumn{1}{|c|}{ Requirement } & \multicolumn{1}{c|}{ Description } \\
\hline WAC $173-400^{\circ}$ & Ambient air quality standards and applicable regulations \\
\hline WAC $173-460^{\circ}$ & Toxic air pollutants \\
\hline WAC $246-247^{\circ}$ & General provisions for national emission standards for hazardous air pollutants \\
\hline 40 CFR $61.92^{\circ}$ & Dose limits of ambient air emissions from DOE facilities \\
\hline
\end{tabular}

"WAC 173-400, "Regulations for Air Pollution Sources," Washington Administrative Code, as amended.

"WAC 173-460, "Controls for New Souces of Toxic Air Pollutants," Washington Administrative Code, as amended.

"WAC 247-247, "Radiation Protection-Air Emissions." Washington Administrative Code, as anended.

${ }^{4} 40$ CFR 61, 1991, "National Emission Standards for Hazardous Air Pollutants," Code of Federal Regulations.

$C F R=$ Code of Federal Regulations.

WAC $=$ Washington Administrativc Code.

DOE $=$ U.S. Department of Energy.

\subsubsection{Liquid Effuents}

The private contractors' treatment facilities will discharge liquid effluents to the ETF for treatment and disposition. The liquid effluents must meet acceptance criteria that are specific to each type of waste. Table 4 lists the applicable requirements (McDonald 1994). The TWRS will use the Treated Effluent Disposal Facility in the 200 East Area for cooling tower blow-down and for clean (no listed constituents or radioactivity) blow-down water from the TWRS private contractors' treatment facilities.

Table 4. Liquid Effluents Acceptance Criteria.

\begin{tabular}{|l|l|}
\hline \multicolumn{1}{|c|}{ Requirement } & \multicolumn{1}{c|}{ Description } \\
\hline WHC-SD-ETF-WAC-001, Rev. 0* & Characterization \\
\hline WHC-SD-ETF-WAC-001, Rev. 0* & TRU limits \\
\hline WHC-SD-ETF-WAC-001, Rev. 0* & Types of waste accepted \\
\hline WHC-SD-ETF-WAC-001, Rev. 0* & Organics \\
\hline WHC-SD-ETF-WAC-001, Rev. 0* & Colloidal matter \\
\hline WHC-SD-ETF-WAC-001, Rev. 0* & Scale-forming compounds \\
\hline WHC-SD-ETF-WAC-001, Rev. 0* & Corrosive constituents \\
\hline
\end{tabular}

*McDonald, F. N., 1994, Acceptance of Feed Streams for Treatment at the LERF/ETF Complex, WHC-SD-ETF-WAC-001, Rev. 0,

Westinghouse Hanford Company, Richland, Washington.

TRU = transuranic: 
HNF-SD-WM-MAR-008 Rev 3

\subsubsection{Solid Waste}

The TWRS will transfer solid waste to the Hanford Site Waste Management facilities for final disposal. The solid waste must meet acceptance criteria that are specific to each type of waste. Table 5 lists the applicable requirements (Willis and Triner 1993).

Table 5. Solid Waste Acceptance Criteria.

\begin{tabular}{|l|l|}
\hline \multicolumn{1}{|c|}{ Requirement } & \multicolumn{1}{|c|}{ Description } \\
\hline WHC-EP-0063-3* & Radionuclide concentration limits \\
\hline WHC-EP-0063-3* & Containment \\
\hline WHC-EP-0063-3* & Surface dose rates \\
\hline WHC-EP-0063-3* & Surface contamination \\
\hline WHC-EP-0063- $3^{*}$ & Thermal power limits \\
\hline WHC-EP-0063-3* & Interior void space \\
\hline WHC-EP-0063-3* & Nuclear criticality \\
\hline
\end{tabular}

*Willis, N. P., and G. C. Triner, 1993, Hanfor Site Solid Wiste Heceprance Criteria, WHC-EP-0063-03, Westinghouse Hanford Conpany, Richland, Washington.

\subsection{TANK WASTE REMEDIATION SYSTEM END STATES}

\subsubsection{Immobilized Low-Activity Waste}

The ILAW will be disposed of onsite in approved land disposal facilities. Project W-465 will renovate the TWRS Grout Facilities to serve as the first part of the $I \mathrm{AWW}$ Disposal Facility. Appendixes B and C of the Tri-Party Agreement (Ecology et al. 1996) assign the Grout Facility to TSD Unit TD-2-1.

Table 6 contains a summary of the regulatory requirements for LAW that is disposed of onsite. These requirements include those that are applicable to an engineered surface barrier for waste sites located at the 200 East and 200 West Areas.

\subsubsection{Immobilized High-Level Waste and Transuranic Waste}

Tank waste previously categorized as TRU will be blended with HLW (Taylor 1996). Interim storage of IHLW will be on site at the CSB. The waste acceptance requirements for the IHLW that is transferred to the OCRWM are contained in the Waste Acceptance System Requirements Doctment (WAS-RD) (DOE-OCRWM 1993). Table 7 contains specific WAS-RD requirements that are applicable to the IHLW. 
Table 6. Immobilized Low-Activity Waste Major Final State Requirements.

\begin{tabular}{|l|l|}
\hline \multicolumn{1}{|c|}{ Requirement } & \multicolumn{1}{|c|}{ Description } \\
\hline NRC Finding & \multicolumn{1}{|c|}{} \\
\hline 40 CFR $241^{b}$ & ILAW will be treated as incidental waste. \\
\hline 40 CFR $264^{\mathrm{c}}$ & Guidelines for the land disposal of solid wastes. \\
\hline 40 CFR $268^{\mathrm{d}}$ & Standards for owners and operators of hazardous waste TSD facilities. \\
\hline DOE Order $5820.2 \mathrm{~A}^{\mathrm{c}}$ & Land disposal restrictions (hazardous waste). \\
\hline $\begin{array}{l}\text { Hanford Federal Facility Agreement and } \\
\text { Consent Order }\end{array}$ & Radioactive waste management. \\
\hline WAC $173-303^{\mathrm{s}}$. & Tri-Party Agreement (with modifications). See Appendix C, Table C-7. \\
\hline WAC $173-400^{\mathrm{h}}$ & Dangerous waste regulations. \\
\hline WAC $173-401^{\mathrm{i}}$ & General regulations for air polintion sources. \\
\hline WAC $173-460^{\mathrm{j}}$ & Operating permit regulations. \\
\hline WAC $246-247^{\mathrm{k}}$ & Control for new sources of toxic air pollutants. \\
\hline $\begin{array}{l}\text { Externally imposed ES\&H requirements } \\
\text { (see Appendix C) }\end{array}$ & Radiation protection - air emissions. \\
\hline
\end{tabular}

'Kinzer, J. E., 1997, Contract Number DE-ACO6-96RL13200 - Nuclear Regulatory Commission (NRC) Agreement of Classification of Hanford Tank IWaste (letter 9755522 to President, Fluor Donicl Hanford, Inc., June 23), U.S. Dejpartment of Energy, Richland Operations Office, Rictland. Washington.

40. CFR 241, 1992, "Guidelines for the Land Disposal of Solid Wastes." Code of Federal Regulations.

"40 CFR 264, 1991, "Standards for Owiers and Operotors of Hazardous Waste Treatnent, Storage, and Disposal Facilities," Code of Federal Regulations.

¿40 CFR 268, 1991, "Land Disposal Restrictions," Code of Federal Regulations.

DOE Order 5\$20.2A, Radioactive Warste Management, U.S. Department of Energy, Washington, D.C.; 1988.

'Ecology, EPA, and DOE, 1996, Hanford Federal Facility Agreement and Consent Order, Washington State Department of Ecology,

U.S. Environmental Protection Agenoy, and U.S. Department of Energy, Olympia, Washington.

BWAC 173-303, "Dangerous Waste Regulations," Washington idministratwe Code, as amended.

"WAC 173-400, "Regulations for Air Pollution Sources," Washington Administrative Code, as amended.

"WAC 173-401, "Opcrating Pernit Regulation," Washington Administrative Code, as antended.

"WAC 173-460, "Controls for New Sources of Toxic Air Pollutants," Washington Administrative Code as amended.

"WAC 246-247, "Radiation Protection--Air Emissions," Washinglon Administrative Code, as anended.

$\mathrm{CFR}=$ Code of Federal Regulations.

DOE $=$ U.S. Department of Encrgy. $\mathrm{NRC}=$ U.S. Nuclear Regulatory Commission.

ES\&H = Environmental, Safety ard Health.

IL AW = immobilized low-sctivity waste.

\author{
Tri-Party Agreement $=$ Fanford Federal Facility Agreement and Consent Order , \\ $\Upsilon S D=$ treatment, storage, and/or disposat. \\ WAC $=$ Washington Administrative Code.
}

\title{
5.4.3 Closed Single-Shell Tank System
}

Single-shell tanks primarily are regulated as RCRA storage facilities. The TWRS is responsible for SST closure (Wagoner 1994, RL 1995). Appendixes B and C of the Tri-Party Agreement (Ecology et al. 1996) assign operable units 200-BP-7, 200-PO-3, 200-RO-4, 200-TP-5, 200-TP-6, and 200-UP-3 to TSD Unit S-2-4, the SST System, for closure. Included are the SSTs, associated diversion boxes, catch tanks, valve pits, and unplanned release sites. 
Table 7. Immobilized High-Level Waste Major Final State Requirements.

\begin{tabular}{|c|c|}
\hline Requirement & Description \\
\hline 10 CFR $60.131(\mathrm{~b})(7)_{,}{ }^{a} 10$ CFR $71.55^{b}$ & Criticality safety \\
\hline 10 CFR $60.135(b)(4)^{3}$ & Canister will be labeled with unique alphanumeric identifier \\
\hline 40 CFR $261^{\circ}$ & Delisting \\
\hline WAS-RD, DOE/RW-035IP, Sect. 3.7.1.2.1.2 & HLW standard form \\
\hline $\begin{array}{l}\text { Tank Waste Remediation System (TWRS) High- } \\
\text { Level Waste (HLW) Canister" }\end{array}$ & Total length \\
\hline WAS-RD, DOE/RW-0351P, Sect. 3.7.1.2.1.2 ${ }^{\mathrm{d}}$ & Canister diameter \\
\hline WAS-RD, DOE/RW-0351P, Sect. 3.7.1.2.1.2 & Maximum weight \\
\hline WAS-RD, DOE/RW-0351P, Sect. 3.7.1.2.1.2.1 & Canister fill height \\
\hline WAS-RD, DOERW-0.35IP, Sect. 3.7.1.2.1.24 & Maximum total heat generation \\
\hline WAS-RD, DOE/RW-035IP, Sect. 3.7.1.2.1.2 & Maximurn storage temperature \\
\hline WAS-RD, DOE/RW-035IP, Sect. 3.7.1.2.1.2 & Maximum inert cover gas leak rate \\
\hline WAS-RD, DOE/RW-0351P, Sect. 3.7.1.2.1.6 & Chemical composition \\
\hline WAS-RD, DOE/RW-035.1P, Sect. 3.7.1.2.1.7 & Canister material \\
\hline WAS-RD, DOE/RW-0351P, Sect. 3.7.1.2.1.8 & Radionuclide inventory \\
\hline WAS-RD, DOE/RW-035IP, Sect. 3.7.1.2.1.1. & Hazardous waste determination \\
\hline WAS-RD, DOE/RW-0351P, Sect. 3.7.1.2.8 & Nonstandard or nonconforming delivery \\
\hline WAS-RD, DOE/RW-0351P, Sect. 3.2.5.1.1.16 & RCRA-regulated wastes ${ }^{f}$ \\
\hline
\end{tabular}

"10 CFR 60, 1992, "Disposal of High-Level Radionctive Wastes in Gcologic Repositories," Code of Fecleral Regulations.

"10 CFR 71, 1992, "Packaging and Transportation of Radionctive Mfaterial," Code of Federal Regulations.

"40 CFR 261, 1996, "Identification and Listing of Hazardous Waste," Code of Federal Regularions.

DOE-OCRWM, 1993, Waste Acceptance System Requirements Document (WAS-RD), DOE/RW-0351P, Rev. 0, U.S. Department of Entergy, Office of Civilian Radioactive Waste Management, Washington, D.C.

Taylor, W. J., 1997b, Contract Number DE-AC06-96R13200-Tank Waste Remediation System (TWRS) High-Level WVaste (HLW) Canister (letter 97-WDD-146 to President, Fluor Daniel Hanford, Inc., September), U.S. Departnent of Energy, Richland Operations Office, Richland, Washington.

${ }^{t} \mathrm{Ecology}, \mathrm{EPA}$, and DOE, 1996, Hanford Federal Facility Agreement and Consen Orde; 2 vol, Washington State Department of Ecology, U.S. Environmental Protection Agency, and U.S. Department of Energy. Olympia, Washington. $\mathrm{CFR}=$ Code of Federal Regulations. RCRA $=$ Resource Conservation and Recovery Act of 1976. HLW $=$ high-level waste.

WAS-RD = Waste Acceptance System Requirements Document $\mathrm{NRC}=\mathrm{U} . S$. Nuclear Regutatory Connission

The Tri-Party Agreement (Ecology et al. 1996, Milestone M-45-00) specifies that SST closure will follow retrieval of as much tank waste as technically feasible, with tank waste residues not to exceed $360 \mathrm{ft}^{3}$ in each of the 100-series tanks, $30 \mathrm{ft}^{3}$ in each of the 200 -series tanks, or the limit of waste retrieval technology capability, whichever is less. In total, these quantitative values represent approximately $1 \%$ of the existing SST waste. The TWRS EIS did not specify tank closure requirements. For planning purposes, it is assumed that tank closure requirements for tank waste residue will be the same as tank retrieval requirements. 
The Single-Shell Tank. Closure Work Plan (RL 1995) provides an overview of the current SST closure strategy. The DOE has not yet provided an ROD on SST closure. Table 8 contains specific requirements known to date pertaining to the closure of SSTs.

Table 8. Final-State Requirements Identified for Closing Single- and Double-Shell Tanks.

\begin{tabular}{|c|c|}
\hline Requirement & Description \\
\hline 10 CFR $835^{\mathrm{a}}$ & Occupational radiation protection - radiation workers. \\
\hline 40 CFR 61 series ${ }^{b}$ & Limits on hazardous air pollutants. \\
\hline 40 CFR 191 Part $B^{\circ}$ & $\begin{array}{l}\text { Disposal of TRU waste and HLW - Total release from facility, individual } \\
\text { protection limits, and a groundwater protection standard. Reissued } \\
\text { December } 1993 \text { by EPA ( } 58 \text { FR } 66398 \text { ). }{ }^{d} \text { Applies if SST tank residuals are } \\
\text { considered to be TRU waste or HLW. }\end{array}$ \\
\hline $40 \mathrm{CFR} 264^{\circ}$ & $\begin{array}{l}\text { Standards for owners and operators of hazardous waste treatment, storage, and/or } \\
\text { disposal facilities. }\end{array}$ \\
\hline DOE Order $5820.2 \mathrm{~A}^{\mathrm{f}}$ & Radioactive waste management. \\
\hline $\begin{array}{l}\text { Hanford Federal Facility } \\
\text { Agreement and Consent Order }{ }^{8}\end{array}$ & Tri-Party Agreement (with modifications). \\
\hline WAC $173-303^{h}$ & Dangerous waste regulations. \\
\hline WAC $173-400^{i}$ & General regulations for air pollution sources. \\
\hline WAC $173-401^{j}$ & Operating permit regulations. \\
\hline WAC $173-460^{k}$ & Control for new sources of toxic air pollutants. \\
\hline WAC $246-247^{\prime}$ & Radiation protection - air emissions. \\
\hline
\end{tabular}

Source: RL, 1995, Single-Shiall Tank Closure Work Plan, DOE/RL-89-16, Rev, 1, U.S. Department of Energy, Richland Oparations Office, Richland, Washington.

"10 CFR 835, 1993, "Occupational Radiation Protection," Code of Federal Regulations.

"40 CFR 6. 1991, "National Emission Standards for Hazardous Air Pollutants," Code of Federal Regulations.

"40 CFR 191, 1991, "Environmental Radiation Protection Standards for Management and Disposal of Spent Nuclcar Fuel, High-Level and Transuranic Radioactive Wastes," Code of Federal Regulations.

¿58 FR 66398, "Environmental Protection Agency," Federal Register, Vol. 58, pp. 66398-66416 (December 20).

" 40 CFR 264, 1991, "Standards for Owners and Operators of Haizardous Waste Treatment, Storage, and Disposal Facilities," Code of Federal Regulations.

TOE Order 5820.2A, Radioactive Waste Wanagement, U.S. Department of Energy, Washington, D.C., 1988.

SEcology, EPA, and DOE, 1996, Hanford Federal Facility Agreement and Consent Order; 2 vols., Washington State Department of Ecology,

U.S. Environmental Protection Agency, and U.S. Depattment of Energy, Olympia, Washington.

"WAC 173-303, "Dangerous Waste Rugulations," Washington ddministrative Code. as amended.

"WAC 173-400, "Regulations for Air Pollution Sources." Washingron Administrative Code, as amended.

WWAC 173-401, "Operating Pernit Regulation," Washington Adninistrative Code. as aniended.

"WAC 173-460, "Controls for New Sources of Toxic Air Pollutants," W/rshington Adminisirative Code, as amended

"WAC 246-247, "Radiation Protection-Air Enissions," Washington Administrative Code, as amended.

$\mathrm{CFR}=$ Code of Federal Regulations. SST $=$ singlc-shell tank.

DOE = U.S. Department of Energy.

EPA $=$ U.S. Environmental Protection Agency.

FR $=$ Federal Register.

Tri-Party Agrcenent $=$ Hanford Federal Facility Agreemen and Consent Order $\mathrm{TRU}=$ transuranic.

HLW $=$ high-level waste.

WAC $=$ Washington Administrative Code 


\subsubsection{Closed Double-Shell Tank System}

It is assumed that TWRS will be responsible for DST closures through its associated operable unit. Appendixes B and C of the Tri-Party Agreement (Ecology et al. 1996) assign the DSTs, selected diversion boxes, the AR and CR Vaults, the EW-151 Vent Station catch tank, and the TX, BX, U, S, and A receiver tanks to TSD Unit S-2-3.

The DSTs are classified as "active treat, store, and dispose" facilities and must be closed in accordance with the clean-closure standards of WAC 173-303-610. It is assumed that requirements for closing the DSTs and the SSTs will be identical. In addition to requirements specified in the National Environmental Policy Act of 1969 (NEPA), Table 8 identifies the requirements pertinent to the closure of the DSTs.

\subsubsection{Closed Miscellaneous Underground Storage Tanks}

Closure of the TWRS-assigned MUSTs is the responsibility of TWRS through its associated tank farm or operable unit. The TWRS MUSTs that support SST operations are included in SST operable units as ancillary equipment, and will be included in SST closure (Wagoner 1994, RL 1995). In addition to requirements specified in NEPA, Table 8 contains specific requirements that are also applicable to the closure of the MUSTs associated with SST farms.

The TWRS MUSTs that support DST operations are included in DST operable units as ancillary equipment and it is assumed that they will be included in DST closure. Specific requirements that are also applicable to the closure of the MUSTs associated with DST farms are listed in Table 8.

\subsubsection{Excess Facilities}

The TWRS will close the tanks, tank farms, and D\&D-associated facilities. The HLW and stored hazardous materials will be removed as part of the last operational activities before entering into the decommissioning phase (DOE Order 5820.2A, Chapter $V$ and NEPA).

\subsubsection{Ancillary Tank Farm Facilities}

It is assumed that TWRS will be responsible for closure of all ancillary tank farm equipment (e.g., pipelines, vaults, diversion boxes). 
HNF-SD-WM-MAR-008 Rev 3

\subsubsection{Beneficial Materials, Reusable Materials, and Technology Transfer}

Any materials or equipment used by TWRS to accomplish the mission will be made available, when no longer needed, for external beneficial use. Any material or equipment transferred must meet applicable environmental, safety, and health regulations, and proper custodial transfer must be observed.

\subsubsection{Phase 2 Mission - Tank Waste Remediation System End States}

The DOE convened the Hanford Future Site Uses Working Group in 1992 and charged the group to evaluate potential future uses of the Hanford Site. This Working Group consists of federal, tribal, state, and local governmental entities and representatives of concerned constituencies. Their findings are published in The Future for Hanford: Uses and Cleantp, $A$ Final Report of the Hanford Future Site Uses Working Group (HFSUWG 1992). Those findings include recommendations for all portions of the Hanford Site, including the 200 East and 200 West Area complexes.

The condition of the waste supports the findings of the Working Group and leads to isolation of the 200 East and 200 West Areas as permanent waste storage zones. Based on these conditions, cost-effectiveness figures of merit will be derived by using the measures of success (Table 10 in Section 9.2 and Table 22 in Section 13.3) related to each TWRS end state.

Consistent with the published recommendations for the future uses of the Hanford Site, the TWRS EIS states that "The 200 Areas and the surrounding Central Plateau have been identified as potential exclusive-use waste management areas to support the Hanford Site's Waste Management and Environmental Restoration programs." The Future for Hanford: Uses and Cleanup, A Final Report of the Honford Future Site Uses Working Group (HFSUWG 1992) indicates that the findings of the Hanford Future Site Uses Working Group (embodied in the Draft Hanford Remedial Action Environmental Impact Statement and Comprehensive Land Use Plan) (DOE 1996) will be used as the guidance for the TWRS Project. Note that TWRS facilities are operated under RCRA regulations and will be closed under RCRA requirements and in compliance with NEPA requirements.

\subsection{TANK WASTE REMEDIATION SYSTEM OPERATIONS AND MAINTENANCE STRATEGY}

The Operations and Maintenance (O\&M) philosophy for existing TWRS facilities and for evolving TWRS facilities will be based on Life-Cycle Asset Management Good Practice Guides GPG-FM-004, Reliability, Maintainability, and Availability Planning; and GPG-FM-031, Maintenance. The O\&M strategy development is iterative in nature and becomes more fully 
developed as the facility planning proceeds through the life-cycle phases and before new operations begin. The strategies for logistics support planning and for systems cost effectiveness for TWRS will be used to determine O\&M strategies for specific systems.

The TWRS O\&M strategy is strongly influenced by the primary interfaces with the immobilization facilities which will be owned and operated by private contractors. Significant penalties and/or increased costs may be incurred if system failures impact critical interfaces with the immobilization facilities. Examples of system failure impacts include loss of the support infrastructure, inability to provide waste feed of sufficient quality or in sufficient quantity, or inability to provide acceptance of the immobilized product. Therefore, the system up-time requirements must be structured to support these needs.

As a result, new TWRS facilities and upgrades of existing TWRS facilities must be designed using an O\&M strategy which ensures that, in case of failure, immobilization operations can be supported with minimal disruption while still supporting as low as reasonably achievable concerns for O\&M staff. This requires system designs to be optimized to meet the availability and reliability needs of the mission. Additionally, systems must be designed and supporting operations must be planned to accommodate parallel processes where they are appropriate (e.g., providing feed and removing waste products).

\subsection{OPERATIONS STRATEGY OVERVIEW}

The current operations strategy is based on requirements for the safe handling, storage, and monitoring of highly radioactive liquid waste. Radioactive liquid wastes are received from interim storage into the DST System by truck, rail car, or transfer lines from external sources such as B Plant, the Plutonium Finishing Plant, and the 222-S Laboratory. Liquid wastes are staged as feed for the 242-A Evaporator campaigns to conserve DST space through waste volume reduction. Evaporator output slurries are received for tank waste storage.

Additional activities include the recovery of pumpable SST waste into the DST System through the interim stabilization program. These liquids are a potential source of feed for the Phase 1 mission while the remaining solids are destined for the Phase 2 mission. Mortgage reduction is accomplished through preparation of retired facilities for turnover to the environmental restoration program. Surveillance activities necessary to support the safe storage function are performed using approved procedures.

Tank Farms has implemented safety and licensing policies and procedures that are patterned after nuclear industry requirements and fully comply with applicable DOE Orders. The Authorization Basis has been upgraded with the approval of the BIO (FDH 1997). The Authorization Basis provides the framework for future amendments to authorize the retrieval and storage activities. Commercial industry evaluation techniques were used to develop a comprehensive hazard analysis that formed the foundation for the Authorization Basis. 
Operations ensures the availability of systems, structures, and components for current and future planned operations within the boundary of the current Authorization Basis. Operations obtains, evaluates, and retains tank waste surveillance data to ensure up-to-date records status of facilities and equipment. The objective includes conducting activities pertaining to operations of a permitted treatment, storage, and disposal facility, ensuring compliance with the WAC. The integrated safety management process, described in greater detail in the TWRS Safety . Management Plan (Popielarczyk 1996) and the Tank Farm Health and Safety Plan (Mickle 1995), has proven very effective in getting a large volume of work completed safely.

Approved operating procedures govern operation of tank farm systems and components under the direct control of shift managers. Examples include primary tank ventilation systems, annulus ventilation systems, waste transfers, in-tank videos, operational tests, and alarm response actions. Preventive and corrective maintenance activities are performed using approved work packages released for field work by the shift manager. Construction upgrades are integrated with O\&M activities.

The operational strategy to support the Phase 1 mission is in development and is based primarily on the operational scenario developed in the Tank Waste Remediation System Operation and Utilization Plan (Kirkbride et al. 1997). The operational strategy is discussed in Section 10.1.2.

The operational strategy will describe how the TWRS systems, structures, and components will function to meet the Phase 1 mission and indicate future efforts required for the entire TWRS Project life cycle. A reliability, availability, and maintainability analysis will be performed to identify those areas of design features and systems/components that could lead to nonavailability of the system. A system availability figure of merit will be calculated that is sufficient to support trade studies to cost effectively balance necessary changes to the TWRS system architecture and/or processes to meet Phase 1 requirements.

\subsection{MAINTENANCE STRATEGY OVERVIEW}

The overall TWRS Maintenance strategy is and will continue to be based on the requirements established by DOE Order 4330.4B, Maintenance Management Program, Chapter 2, "Nuclear Facilities." The current maintenance program has been focused on maintaining the operation of tank farms in a storage and surveillance mode.

When the operational requirements are established to support the TWRS retrieval and disposal mission; the maintenance strategy will be revised to provide best-value maintenance and logistics support throughout the operational life cycle of the mission. The TWRS Phase 1 maintenance strategy for the initial Phase IB waste feed delivery is outlined in the Tank Waste Remediation System Program Plan (Freeman 1998).

Movement to an emphasis on Phase 1 and Phase 2 missions will require the maintenance program to shift to a production mode orientation. For TWRS Maintenance to accomplish this 
transition, several changes in the operation of the maintenance programs will be made. The changes are centered around the following areas:

- Integrated schedule for TWRS maintenance

- Preventive maintenance program enhancement

- Reliability-centered maintenance

- Maintenance staffing increases

- Major elements of logistics support including spare parts inventories.

The effective scheduling of maintenance is essential in meeting waste feed production commitments. Most maintenance activities will be scheduled during planned equipment downtime or scheduled system outages. Planned outages will be identified on the integrated schedule with each outage having its own detailed schedule. This outage planning and scheduling will enable TWRS Maintenance to plan, schedule, stage materials, and execute corrective and preventive maintenance for a single system within the time constraints permitted without impacting the production schedule.

While the preventive maintenance program today mostly focuses on Authorization Basis requirements, the program will be required to focus on the early detection of conditions that will lead to equipment failure and take actions that will ensure reliability of equipment over its design life.

The use of reliability-centered maintenance and predictive maintenance techniques is supported by the Maintenance Management Program (DOE Order 4330.4B), Maintenance Optimization Plan for Essential Equipment Reliability (Steffen 1996), and the Institute of Nuclear Power Operations Preventive Maintenance and Plant Predictive Maintenance Bulletins (INPO 85-032 1985 and INPO 89-009 1989]). Implementation of predictive maintenance techniques will permit the monitoring of operating equipment in a nonintrusive manner. This will assist in the early detection of future equipment failures. Using predictive maintenance techniques will ensure that early signs of failure will be detected and corrective action can be scheduled during planned equipment downtime.

The maintenance staff will be required to increase to support the Phase 1 mission. The TWRS Maintenance organization has sufficient depth to ensure that the proper resources can be focused to provide the required level of support.

Logistics will provide the support for procurement, distribution, maintenance, and replacement of material and personnel for TWRS. Logistics support plans will be prepared for each new or modified TWRS facility. For each major TWRS facility, analyses will be conducted to define staffing requirements; maintenance requirements; support equipment; spares inventory; technical data requirements; training requirements; maintenance facility needs; and packaging, handling, storage, and transportation requirements for repair parts. 


\subsection{TEST AND EVALUATION PROCESSES FOR THE TANK WASTE REMEDIATION SYSTEM MISSION}

\subsection{TEST AND EVALUATION OVERVIEW}

Test and evaluation (T\&E) processes will include the set of activities that are performed throughout the life cycle of each major TWRS facility to ensure that the end product of construction projects or of facility operations meets mission objectives, functions, and performance requirements as defined in the Technical Baseline. The $T \& E$ activities will begin early in the facility/project planning phase and continue through design, construction, turnover, and operations. The closeout phase will require limited $T \& E$ activity because each facility requires only limited surveillance until deactivation and closure activities have been completed. Figure 6 shows an overview of T\&E activities.

A graded approach will be used to ensure T\&E principles and practices are incorporated commensurate with project and program factors, such as complexity, visibility, and risk, to ensure successful project and program completion. The scope of T\&E activities includes the following

- Concept and alternative validation testing performed during the initial design phase

- In-process inspection activities performed during the manufacturing and/or construction activities

- Vendor testing performed during process design, manufacturing, and construction

- Component post-installation acceptance tests and integrated system operational testing

- Functional testing, inspection, and maintenance performed during operational activities

- $\quad$ Surveillance performed during deactivation activities.

Key inputs to the T\&E process will be the performance requirements of the facility. These performance requirements will be derived from the facility mission, functional analysis, and design constraints (laws and regulations, codes and standards, and organizational policies such as DOE Orders). The complete set of performance requirements will be developed as part of the engineering process and design effort. Once the performance requirements have been established, acceptance criteria will be developed to provide a performance measure that demonstrates that the item under test meets its performance requirements. Acceptance criteria will provide measurability, quantification, completeness, currentness, accuracy, consistency, and traceability. 
Figure 6. Test and Evaluation Activities.

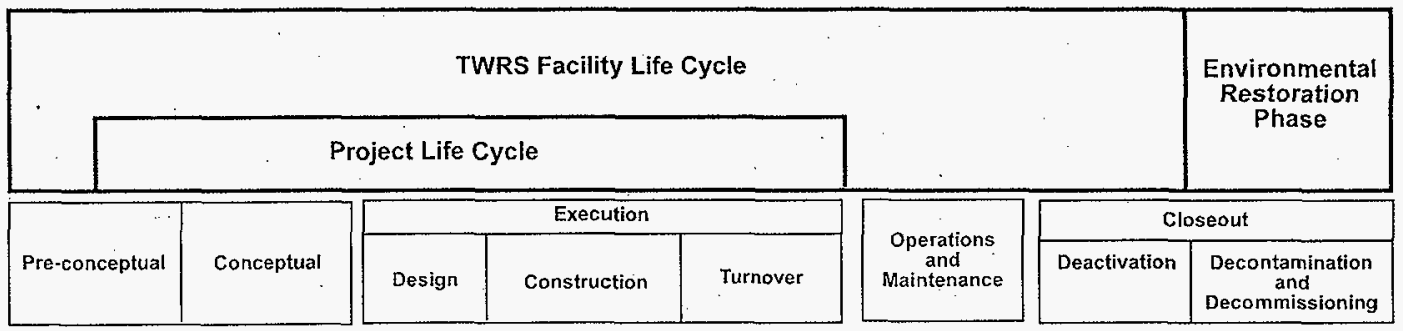

\section{Test and Evaluation}

\begin{tabular}{|c|c|c|c|c|c|}
\hline $\begin{array}{l}\text { - Concept } \\
\text { Verification } \\
\text { Testing }\end{array}$ & $\begin{array}{l}\text { Alternative } \\
\text { Verification } \\
\text { Testing } \\
\text { - Acceptance } \\
\text { Criteria } \\
\text { - Preliminary Test } \\
\text { and Evaluation } \\
\text { Plans }\end{array}$ & $\begin{array}{l}\text { Final Test and } \\
\text { Evaluation Plans } \\
\text { - Design Modeling } \\
\text { and Analysis } \\
\text { - In-Process } \\
\text { Inspection } \\
\text { - Vendor Testing }\end{array}$ & $\begin{array}{l}\text { - Acceptance Testing } \\
\text { - Operational Testing } \\
\text { - Evaluation of Testing } \\
\text { Results } \\
\text { - Documentation of } \\
\text { Testing Results } \\
\text { - Integrated Cold and Hot } \\
\text { Operational Testing } \\
\text { - Operational Readiness } \\
\text { - Review or Readiness } \\
\text { Assessment }\end{array}$ & $\begin{array}{l}\text { - Surveillance Testing } \\
\text { for Technical Safety } \\
\text { Compliance } \\
\text { Requirement } \\
\text { - Asset Maintenance } \\
\end{array}$ & $\begin{array}{l}\text { - Limited Surveillance } \\
\text { Activities }\end{array}$ \\
\hline
\end{tabular}

TWRS = Tank Waste Remediation System 
When the acceptance criteria and performance requirements have been established by the facility/project, specific T\&E methods will be selected and T\&E activities will be planned and scheduled. Selection of the most appropriate T\&E method or methods for a given performance requirement should be based on the following:

- The method that can be applied as early as possible in the project life cycle to demonstrate compliance

- The method or combination of methods most effective for demonstrating compliance

- The methods that are most efficient when considering risk.

The T\&E plan will identify $T \& E$ activities that are required to verify each performance requirement has been satisfied. Performance requirements will be verified through one of the following methods: modeling/analysis, laboratory process testing, in-field demonstration testing, in-process inspection, veridor testing, or post-installation acceptance and operational tests. The complete set of T\&E results will be reviewed and evaluated against performance requirements as part of the turnover process. Any issues noted during this assessment will be formally documented before turnover. An action item list will be developed to resolve these issues before turnover. Construction Project T\&E reports should provide the traceability among the design requirements, $T \& E$ activities, and $T \& E$ results to demonstrate that the project end products comply with the Technical Baseline requirements.

Once a TWRS Project turnover is complete, T\&E activities will be based on operational surveillance activities and asset maintenance activities. Operational surveillance activities will be performed to demonstrate that the facilities' systems, structures, and components comply with identified Technical Safety Requirements. Maintenance activities will preserve and restore the availability, operability, safety, and reliability of these TWRS assets so that they support the mission and fulfill their intended life cycles and purposes.

Once a TWRS facilities' O\&M phase is transitioned to the closeout phase, the T\&E activities will transition to a limited surveillance phase. During the limited surveillance phase, the facility will require $T \& E$ activities to ensure process equipment does not fail and release residual radioactive or hazardous materiais. During this phase, records will be kept to identify systems and/or components that may be deteriorating and to inform decommissioning personnel about potential hazards. Adequate T\&E activities will be maintained for the entire period between shutdown and decommissioning. 


\subsection{PHASE 1 MISSION TECHNICAL STRATEGY}

Fluor Daniel Hanford, Inc, has developed an overall cleanup strategy for the Hanford Site. This strategy has been developed using systems engineering methods and the results are currently contained in the HSTD. The high-level structure of the HSTD contains six major functional (strategic) areas: (1) maintain safe and compliant envelopes, (2) clean up Central Plateau sites, (3) treat waste and material, (4) store waste and material, (5) disposition waste and material, and (6) provide infrastructure. The high-level strategies identified in Sections 8.1, 8.2, and 11.2 fit within one or more of these major strategy categories.

\subsection{STRATEGTES COMMON TO PHASE 1 AND PHASE 2 MISSIONS}

During the development of the mission, it was desirable to have continuity between the Phase 1 and Phase 2 missions to reduce life-cycle costs for the mission.

Several technical strategies were determined to be common to both the Phase 1 and the Phase 2 missions (62 FR 8693). These strategies include the following:

- Upgrading tank farm infrastructure, including waste transfer, instrumentation, ventilation, and electrical systems

- Monitoring tanks and equipment to support waste management and regulatory compliance requirements

- Combining compatible waste types, continuing waste characterization, removing pumpable liquid from SSTs, transferring newly generated waste from ongoing Site activities to DSTs, and mitigating and resolving tank safety issues

- Using rail or tanker truck systems to transport waste to the tank farms

- Continuing to characterize the tank waste and to perform technology development activities that reduce uncertainties associated with remediation, to evaluate emerging technologies, and to resolve regulatory compliance issues

- Blending TRU tank waste with HLW and immobilizing the waste for disposal in the national geologic repository (Taylor 1996).

\subsection{PHASE 1 MISSION TECHNICAL STRATEGIES}

From the view of the TWRS EIS ROD (62 FR 8693), the Phase 1 activities (Phase 1A, developmental activities; Phase $1 \mathrm{~B}$, demonstration) that support the mission will last for 14 years. 
It is desirable to build Phase 1 facilities so that additional capacity can be added for the Phase 2 mission. Technical strategies for the Phase 1 mission include the following:

- Constructing expandable demonstration-scale facilities to produce ILAW and IHLW for future disposal

- Installing and operating an initial tank waste retrieval system to improve capacity to.allow consolidation of DST waste, support mitigation of safety issues, and deliver LAW/HLW feed to the private contractors

- Installing and operating retrieval systems to retrieve selected tank waste (primarily liquid waste) for separation and immobilization, and selected tank waste for HLW immobilization

- Completing construction, and beginning operation, of the new replacement cross-site transfer system to facilitate regulatory-compliant waste transfers from the 200 West Area to the 200 East Area and continuing to operate the existing transfer pipeline system until the replacement system is operational

- Transferring LAW to private contractor feed tanks and transferring selected waste for HLW processing directly to the HIW facility

- Performing separations to remove selected radionuclides (e.g., cesium) from the LAW stream

- Returning a portion of the sludge, strontium, and TRU waste from separations processes to the DSTs for future retrieval and treatment during Phase 2

- Immobilizing the LAW and HLW

- Transporting the ILAW to permanent onsite disposal facilities and IHLW to onsite interim storage facilities

- $\quad$ PHMC D\&D of Phase 1 facilities.

\subsection{PHASE 1 MISSION GOALS, OBJECTIVES, AND MEASURES OF SUCCESS}

\subsection{PKASE 1 MISSION GOALS AND OBJECTIVES}

The primary goals and objectives for the Phase 1 mission are derived from the Jusification of Mission Need (DOE 1993), the Tri-Party Agreement (Ecology et al. 1996), and 
the TWRS EIS ROD (62 FR 8693). Table 9 shows the goals and objectives. In addition to these goals and objectives, TWRS Project programs will ensure that before new or changed facilities are put into operation, the following objectives are met: changes in the BIO are satisfactorily implemented; procedures are acceptable; training and qualification of staff has occurred; staffing levels have been adequately established for the facility; safety documentation, management systems, and emergency preparedness systems are in place; test programs have been carried out and equipment proven to meet requirements; and Conduct of Operations has been adequately established. That is, TWRS will ensure that equipment, personnel, and procedures are in place before proceeding with operations.

Table 9. Tank Waste Remediation System Phase 1 Mission Goals and Objectives.

\begin{tabular}{|c|c|}
\hline Goal & Objective \\
\hline \multirow{3}{*}{$\begin{array}{l}\text { Operate and maintain facilities to provide } \\
\text { continued safe and environmentally sound } \\
\text { storage }\end{array}$} & Resolve tank system safety issues. \\
\hline & Upgrade facilitics as necessary until they can be closed. \\
\hline & $\begin{array}{l}\text { Reduce operating costs to acceptable levels necessaty to sately manage } \\
\text { the tank waste. }\end{array}$ \\
\hline \multirow[t]{6}{*}{$\begin{array}{l}\text { Demonstrate preparation/delivery of feed to } \\
\text { the private contractors' plants }\end{array}$} & $\begin{array}{l}\text { For SSTs retrieved, leave no more than } 360 \mathrm{ft}^{3} \text { of waste in } 100 \text {-series } \\
\text { tanks, } 30 \mathrm{ft}^{3} \text { of waste in } 200 \text {-series tanks or to the limit of waste retrieval } \\
\text { teclmology. }\end{array}$ \\
\hline & Remove waste from DSTs to make space for SST retrieval. \\
\hline & $\begin{array}{l}\text { Reduce operating costs to acceptable levels necessary to safely retrieve } \\
\text { the tank waste. }\end{array}$ \\
\hline & Supply waste feed batches with an acceptable composition. \\
\hline & Supply waste feed batches in acceptable quantities. \\
\hline & Supply waste feed batches at an acceptable rate. \\
\hline \multirow[t]{3}{*}{ Immobilize and dispose of LAW } & Achieve acceptable levels of safety and environmental risk. \\
\hline & Provide disposal of ILAW. \\
\hline & $\begin{array}{l}\text { Reduce costs to acceptable levels necessary to safely immobilize the } \\
\text { LAW. }\end{array}$ \\
\hline \multirow{4}{*}{$\begin{array}{l}\text { Immobilize HLW and TRU constituents of } \\
\text { waste }\end{array}$} & Achieve acceptable levels of safety and environmental risk. \\
\hline & Enable permanent disposal. \\
\hline & Provide interim storage of HLW. \\
\hline & $\begin{array}{l}\text { Reduce costs to acceptable levels necessary to safely immobilize the } \\
\text { HLW and TRU waste. }\end{array}$ \\
\hline
\end{tabular}

Sources: DOE, 1993, Justification of Mission Need. Hanford Site Tant Waste Remediation System to the Energy System Acquisition Advisony Board, U.S. Department of Energy, Washington, D.C.; Ecology, EPA, and DOE, 1996, Hanford Federal Facility Agrcement and Consent Order,

2 vols., Washington State Department of Ecology, U.S. Environmental Protection Agency, and U.S. Department of Energy, Olynipia, Washiagton; and 62 FR 8693 , "Record of Decision for the Tank Waste Remediation System, Hantord Site, Richland, WA," Federal Register, Vol. 62, pp. 8693-8704 (February 26).

DST $=$ double-shell tank.

HLW $=$ high-level waste.

ILAW = immobilized low-setivity waste.

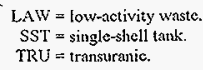




\subsection{PHASE 1 MISSION MEASURES OF SUCCESS}

The measures of success for the TWRS Project are based on a desired TWRS end state. These measures of success will be used to verify that TWRS is effectively executing its mission. The measures listed here are high-level and of a summary nature. Some portion (or decomposition) of all these measures and the goals and objectives previously listed are used as performance indicators which are found in detailed mission schedules. Table 10 summarizes the measures of success for the TWRS Phase 1 mission end states.

Table 10. Measures of Success - Tank Waste Remediation System Phase 1 End States (December 31, 2010).

\begin{tabular}{|c|c|}
\hline TWRS acceptable end state. & Measure of success \\
\hline DSTs & $\begin{array}{l}\text { The contents of } 12 \text { DSTs will be retrieved to support Phase } 1 \\
\text { activities by the end of the Phase } 1 \text { time frame. }\end{array}$ \\
\hline SSTS & $\begin{array}{l}\text { Two SSTs will have completed retrieval activities in support of } \\
\text { Phase l activities. }\end{array}$ \\
\hline ILAW & $\begin{array}{l}\text { A total average feed rate of } 4 \mathrm{MT} \text { of sodium per day to the LAW } \\
\text { Immobilization Plants will be achieved during Phase } 1 \text {. }\end{array}$ \\
\hline IHLW & $\begin{array}{l}\text { An average feed rate of } 0.164 \mathrm{MT} \text { NVOL per day to the HLW } \\
\text { Immobilization Plant will be achieved during Phase } 1 \text {. }\end{array}$ \\
\hline ILAW disposal & $\begin{array}{l}\text { Facilities that are capable of disposing of } 15,000 \text { canisters of ILAW } \\
\text { produced during Phase } 1 \text {. }\end{array}$ \\
\hline IHLW storage & $\begin{array}{l}\text { Facilities that are capable of storing } 1,200 \text { canisters of IHLW } \\
\text { produced during Phase } 1 \text {. }\end{array}$ \\
\hline
\end{tabular}

Source: Kirkbride, R.A., G. K. Allen, P. J. Certa, A. F. Manuel, R. M. Ome, L. W. Shelton, E. J. Slanthaug, R. S. WVittnan (NHC),

G. T. MacLean, and D. L. Penwell (SESC); 1997, Tank Waste Remediation System Operation and Utilization Plan, HNF-SD-WhI-SP-012, Rev. 0,

Vol. I and II, prepared by Numntec Hanford Corporation for Fluor Daniel Hanford, Inc., Riclland, Washington.

DST $=$ doublc-shell tank. . NVOL $=$ nonvolatilt oxide less sodium and silicon.

IHLW $=$ immobilized high-jevel waste.

ILAW $=$ immobilized low-activity waste.

SST $=$ single-shcll tark.

TWRS $=$ Tank Waste Remediation System $\mathrm{MT}=$ metric ton.

\subsection{PHASE 1 MISSION SUMMARY ANALYSIS}

This section summarizes the requirements analysis that has been performed, identifies the major facilities that must be implemented to achieve the mission, identifies the major construction projects that will modify or construct TWRS facilities, and makes conclusions and recommendations for the TWRS Project: Section 13.0 provides a brief analysis of Phase 2 of the mission with recommendations. Recommendations (for both Phase 1 and Phase 2 ) found in this 
section and in Section 13.0, if implemented, could provide a substantial cost reduction for the mission by requiring smaller immobilization plants (smaller melters) and fewer retrieval systems which must be operated simultaneously for the mission.

\subsection{PHASE 1 MISSION ANALYSIS INTRODUCTION}

The DOE is negotiating with private contractors for the treatment and immobilization of Hanford Site tank wastes. The private contractors will perform the work in a phased approach that begins with a demonstration of processing technology that removes wastes from the DST System and makes space for later activities of Phase 1. During Phase 2, the contract will assign to a private contractor the responsibility for waste retrieval, waste conditioning, waste staging, and full-scale waste immobilization systems from the SST System and the DST System (Kirkbride et al. 1997).

Figure 7 provides an illustration of the TWRS facilities and a visual reference for the bounds of the mission analysis. The light gray shaded area labeled "Privatization Phase I" shows the two demonstration immobilization plants operated by the private contractors. The dark gray area labeled "Privatization Phase 2" shows the facilities that will be operated by private contractors during the Phase 2 process.

Waste from DSTs and SSTs (C-106 and C-104) will be retrieved during Phase 1 and will be immobilized. Other SST waste retrieved during Phase 1 will be stored in DST space made available by DST retrieval activities for waste feed to the immobilization facilities.

Using the specified requirements, target tanks were selected based on the "best basis" characterization data. Operations scenarios describing retrieval, transfer, and staging of the waste feeds required to meet Phase 1 requirements were developed (Kirkbride et al. 1997). The analysis presented here will revolve around the requirements for waste inputs to the private contractors' ILAW and the IHLW plants. Input requirements for the immobilization plants concern the capability of TWRS to deliver waste feed in a timely manner to the private contractors' feed tanks. Sections 10.2.1 through 10.2.4 and Section 10.2.6 discuss these requirements.

Output requirements relating to the private contractors' immobilization plants concern the primary product, packaged or canistered immobilized waste. These packages must be received and stored or disposed. Sections 10.2.5 and 10.2.7 discuss the ILAW and IHLW package flow and storage and disposal analysis. Section 10.3 lists the proposed facilities and their functions which will be required to carry out the Phase 1 mission. 
Figure 7. Tank Waste Remediation System Mission Overview.

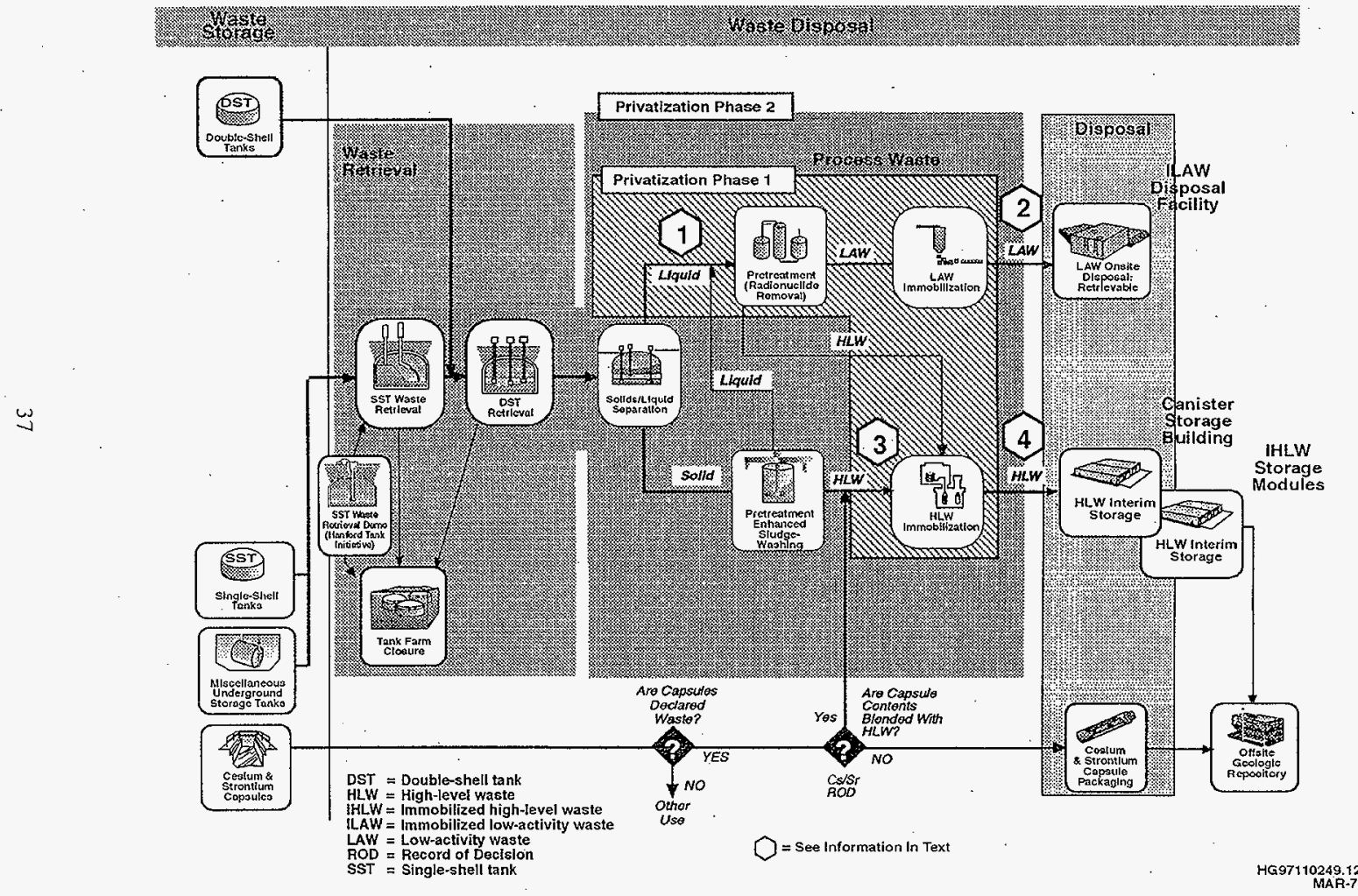




\subsubsection{Feed Envelopes}

During Phase 1, the PHMC Team will deliver the waste feeds to the private contractors' plants (see Figure 7, hexagon numbers 1 and 3 ). The private contracts specify the delivery schedule, waste quantities, and waste composition as feed envelope specifications. Four such envelopes are defined for Phase 1. The tank farm equipment configuration required to supply waste feed, for each Phase 1 waste batch (LAW and HLW) needed to fulfill the requirements of these various envelopes, has been determined. The privatization Request for Proposal defines four feed envelopes ( $A, B, C$, and $D$ ) to demonstrate the private contractors' processing capabilities. Table 11 summarizes these envelopes.

Table 11. Waste Feed Envelopes Summary.

\begin{tabular}{|l|l|}
\hline Envelope & \multicolumn{1}{|c|}{ Description } \\
\hline A & $\begin{array}{l}\text { Waste that tests the production capacity and fission-product removal efliciency. Prodiuces a final } \\
\text { product in which waste loading is limited by sodium. }\end{array}$ \\
\hline $\mathrm{B}$ & $\begin{array}{l}\text { Similar to } \mathrm{A}, \text { except that final product waste loading is limited by minor component concentrations }(\mathrm{Cl}, \\
\left.\mathrm{Cr}, \mathrm{F}, \mathrm{PO}_{4}, \text { or } \mathrm{SO}_{4}\right) . \text { These minor components may stress the private contractors' facilities' offgas } \\
\text { system. }\end{array}$ \\
\hline C & $\begin{array}{l}\text { Contains organic complexants, } \\
\text { the low-activity waste stream. May require organic destruction. }\end{array}$ \\
\hline $\mathrm{D}$ & $\begin{array}{l}\text { Contains insoluble solids which are classified as high-level waste. The envelope approximates solids } \\
\text { content in three existing double-shell tanks: } \mathrm{AZ}-101, \mathrm{AZ}-102 \text {, and } \mathrm{AY} \text {-102 (including C-106). }\end{array}$ \\
\hline
\end{tabular}

$T R U=$ transuranic.

\subsubsection{Operating Scenarios}

The Phase $1 \mathrm{~B}$ operating scenario includes the activities necessary to mix, transfer, stage, adjust, deliver, process, interim store, and dispose of the immobilized wastes. The operating scenario was checked for consistency with contract requirements and enabling assumptions. The scope of this operating scenario includes the following:

- Retrieval, preparation, and delivery of HLW and LAW feed

- Return to the DST System of entrained solids and separated ${ }^{90} \mathrm{Sr} / \mathrm{TRU}$ from the private contractors

- Return of ILAW to the PHMC Team for disposal

- Return of IHLW to the PHMC Team for interim storage 
- Receipt and management of waste from facility cleanout, salt well pumping, and retrieval of SSTs.

This operating scenario was split into several key steps as follows.

- Applicable requirements from the private contracts and major enabling assumptions were identified.

- Specific DSTs that contain waste that would be used to satisfy the quantity and sequence requirements of the waste feed envelopes were identified and the. sequence of batches was established

- Delivery dates and process durations for each batch were determined to ensure a steady supply of feed at the assumed processing rate.

- Specific waste transfers and processing activities needed to prepare and deliver each batch of feed were established.

- Volume and timing of the IHLW, ILAW, entrained solids, and separated ${ }^{20} \mathrm{Sr} / \mathrm{TRU}$ being returned from the private contractors were estimated based on contract requirements and flowsheet considerations.

- The operating scenario was checked for consistency with contract requirements and enabling assumptions.

\subsubsection{Requirements and Assumptions}

The requirements and major enabling assumptions that significantly influence the operating scenario are listed in Tables 12 and 13, respectively. The operating scenario was developed using these requirements and assumptions. Comparisons of each requirement against the operating scenario demonstrate that the requirement is supported by the detailed plans and expected system performance.

\subsection{PHASE 1 MISSION ANALYSIS}

\subsubsection{Phase 1 Low-Activity Waste Feed Processing}

The TWRS LAW feed delivery sequence is a process in which waste is retrieved, prepared, and delivered to the private contractors' feed tanks (see Figure 7, hexagon indicator 1) 
HNF-SD-WM-MAR-008 Rev 3

Table 12. Major Requirements that Influence the Operating Scenario.

\begin{tabular}{|l|l|}
\hline \multicolumn{1}{|c|}{ Major requirement } & \multicolumn{1}{|c|}{ Area influenced } \\
\hline Envelope definitions for LAW and HLW feed & LAW feed; HLW feed \\
\hline Order quantities for LAW and HLW feed & $\begin{array}{l}\text { LAW feed; HLW feed } \\
\text { IHLW interim storage } \\
\text { ILAW disposal }\end{array}$ \\
\hline Minimum batch sizes for LAW and HLW feed & LAW feed; HWW feed \\
\hline Minimum system capacity demonstration & $\begin{array}{l}\text { LAW feed; HLW feed } \\
\text { IHLW interim storage } \\
\text { ILAW disposal }\end{array}$ \\
\hline $\begin{array}{l}\text { Schedule for proof-of-concept (processing minimum order quantities) and } \\
\text { extension period (processing maximum order quantities) }\end{array}$ & $\begin{array}{l}\text { LAW feed; HLW feed } \\
\text { IHLW interim storage } \\
\text { ILAW disposal }\end{array}$ \\
\hline $\begin{array}{l}\text { Minimum WOL in IHLW } \\
\text { Maximum ILAW package volume per unit of LAW feed delivered }\end{array}$ & IHLW interim storage \\
\hline $\begin{array}{l}\text { HLW }=\text { high-level waste. } \\
\text { ILAW = immobilized higl-level waste. }\end{array}$ & LAW = low-activity waste. \\
\hline
\end{tabular}

in a series of batches throughout Phase 1. Kirkbride et al. (1997) states that "the operating scenario for delivery of feed to the privatization LAW contractors was revised to reflect current contract requirements rather than requirements from the Phase 1 Request for Proposal."

The two primary sources of LAW feed are tanks containing supernate liquid or supernate liquid on top of sludge, and tanks containing salt slurry or supernate liquid with salt slurry. In the first case, the supernate liquid will be the waste desired for retrieval; in the second case, the combined supernate liquid and salt slurry after dissolution of the solids will be the waste desired for retrieval. The waste desired for retrieval is called the targeted waste.

The strategy for staging LAW feed will use two intermediate staging tanks. The targeted waste will be retrieved and transferred to the staging tanks (AP-102 and AP-104), blended and adjusted as needed, and verified to meet the envelope requirements. Next, the feed will be transferred to the private contractors' feed tanks (AP-106 and AP-108) when the private contractors are ready to receive the next batch. When the PHMC Teams' staging tanks are emptied, the waste for the next feed batch will be retrieved.

The total TWRS LAW feed delivery to both private contractors' plants is listed in Table 14. Batches and corresponding envelope specifications are as indicated. More than 14.7 million liters ( $3.9 \mathrm{Mgal}$ ) of LAW (approximately 4 to 5 molar $\mathrm{Na}$ ) will be converted to approximately 49.2 million liters (13 Mgal) of LAW feed by waste retrieval, waste separation, 
Table 13. Major Enabling Assumptions that Influence the Operating Scenario.

\begin{tabular}{|c|c|}
\hline Major enabling assumption & Area influenced \\
\hline $\begin{array}{l}\text { Two.LAW facilities } \\
\text { One HLW facility }\end{array}$ & $\begin{array}{l}\text { LAW feed; HEW feed } \\
\text { IHLW interim storage } \\
\text { ILAW disposal }\end{array}$ \\
\hline Maximum order quantities will be processed & $\begin{array}{l}\text { LAW feed; HLW feed } \\
\text { IHEW interim storage } \\
\text { ILAW disposal }\end{array}$ \\
\hline $\begin{array}{l}\text { Constant HUW processing rate of } 0.164 \mathrm{MT} \text { NVOL/day (averaged over } \\
\text { each individual feed batch) }\end{array}$ & $\begin{array}{l}\text { HLW feed } \\
\text { IHLW interim storage }\end{array}$ \\
\hline $\begin{array}{l}\text { Constant LAW processing rate of } 2 \mathrm{MT} \text { sodium/day/contractor (averaged } \\
\text { over each individual feed batch) }\end{array}$ & $\begin{array}{l}\text { LAW feed } \\
\text { ILAW disposal }\end{array}$ \\
\hline IHLW is delivered at the minimum allowable WOL & IHLW $W$ storage \\
\hline $\begin{array}{l}\text { Approximately } 600 \text { canisters (3-m }[10-\mathrm{ft}] \text { length) allocated for } \mathrm{HHLW} \\
\text { storage per vault }\end{array}$ & IHLW storage \\
\hline $\begin{array}{l}\text { The private contractors achieve the values of ILAW package volume per } \\
\text { unit of LAW feed delivered resulting in approximately } 15,000 \text { canisters } \\
\text { during Phase } 1\end{array}$ & LAW disposal \\
\hline $\begin{array}{l}\text { LAW feed will be qualified (certified) in the source tank when necessary } \\
\text { to support the assumed processing rates }\end{array}$ & LAW feed \\
\hline $\begin{array}{l}\text { The tank space projections in the Operational Waste Volume Projections* } \\
\text { remain valid }\end{array}$ & LAW feed; HLW feed \\
\hline $\begin{array}{l}\text { The entire feed qualification process takes no longer than } 85 \text { days for } \\
\text { LAW feed and } 68 \text { days for HLW }\end{array}$ & LAW feed; HILW feed \\
\hline
\end{tabular}

*Strode, J. N., and V. C. Boyles, 1997, Operational Waste Volume Projection, HNF-SD-WM-ER-029, Rev, 23, prepared by Lockheed ilartin Hanford Corporation for Fluor Danicl Hanford. Inc., Ricliland, Washington.

$\mathrm{HLW}=$ high-level waste.

IHL $W=$ immobilized ligh-level wastc.

ILAW $=$ immobilized low-activity waste.

$\mathrm{MT}=$ netrio ton.

$\mathrm{NVOL}=$ nonvolatile oxide less sodiun and silicon.

$\mathrm{LAW}=10 \mathrm{w}-$ activity waste.

WOL $=$ waste oxide loading.

and waste preparation activities, and will be processed by the private contractors' plants during Phase 1. With the assumption that the private contractors will take feed at an average rate during Phase 1 , the flow rate delivered to each private contractor will average approximately $2 \mathrm{MT}$ of sodium per day. This rate, for each contractor, includes the resource delays inherent in the TWRS waste feed delivery cycle and is approximately equal to a pretreated waste feed rate of $7.6 \mathrm{~L}$ (2 gal) per minute.

The LAW feed envelope ( $A$ to $C$ ) composition requirements were developed such that the limits would encompass the majority of DST waste. The composition of the targeted waste in each DST was evaluated by using the best available tank characterization data. Dilution water 
needed to retrieve and transfer the waste and the dissolution and/or precipitation of solids after dilution was taken into account to estimate compositions for the "targeted waste." The composition of the targeted waste in each DST was then compared to the envelope limits and each tank was classified in the appropriate envelope. In addition, laboratory process testing is being performed to confirm the dissolution behavior, transport properties, and composition of the targeted waste that is planned for delivery as feed.

The DSTs that will be used to provide the feed were selected and the processing sequence established to be consistent with the order quantities and envelope orders specified in the private contracts. The selected sequence considered logistics whenever there was flexibility in meeting the contract requirements. These included consideration of how close the targeted feed was to the envelope limits, ease of retrieval, integration of tank usage with the operation waste volume projections, emptying source tanks promptly and processing more dilute waste first to free up tank space more quickly, and simplification of project design and construction schedule.

Table 14 summarizes the available quantities of LAW feed and how much will be scheduled to be delivered to the private contractors. The operating scenario is considered robust enough to allow meeting the minimum to maximum order quantities.

\subsubsection{Staging Transfers}

The waste transfers required to support the operating scenario were determined from the feed sequence and required processing activities. It is expected that Tank Farms will also conitinue to make other transfers not directly related to staging of feed. These other transfers will be required to support ongoing waste management activities. such as receipt of facility waste, salt well pumping, SST retrieval, and operation of the 242-A Evaporator. The feed staging and waste management transfers were analyzed to ensure that the demands on tank space will not exceed available DST space.

\subsubsection{Batch Cycle Time}

The staging strategy for LAW requires that the staging tanks (AP-102 and AP-104) be essentially empty before the next batch of feed is retrieved. The next feed batch must be ready before the private contractor finishes processing the previous batch. This means that the amount of time available for staging (retrieval, transfer, and adjustment) a feed batch will be constrained by the time required to process the previous feed batch. 
Table 14. Low-Activity Waste Source Tanks and Feed Batches.

\begin{tabular}{|c|c|c|c|c|c|c|c|c|c|c|c|c|c|c|c|c|c|}
\hline \multirow{2}{*}{ Envelope } & \multirow{2}{*}{ Batch } & \multicolumn{3}{|c|}{ Available feed ${ }^{3}$} & \multirow{2}{*}{$\begin{array}{l}\text { Dilution water } \\
\text { (ML) }\end{array}$} & \multirow{2}{*}{$\begin{array}{l}\text { Pre-stage tank } \\
\text { (static date) }\end{array}$} & \multicolumn{4}{|c|}{ Approximate timing ${ }^{b}$} & \multicolumn{4}{|c|}{ Feed delivered to each contractor } & \multirow[b]{2}{*}{ Batch - contractor } & \multicolumn{2}{|c|}{$\begin{array}{l}\text { Total feed delivered for both } \\
\text { contractors: }\end{array}$} \\
\hline & & $\begin{array}{l}\text { Source tank } \\
\text { (static date) }\end{array}$ & $\begin{array}{l}\text { Sodium } \\
\text { (MT) }\end{array}$ & $\begin{array}{l}\text { Volume } \\
\text { (ML) }\end{array}$ & & & $\begin{array}{c}\text { Start } \\
\text { retrieval }\end{array}$ & $\begin{array}{c}\text { Begin } \\
\text { staging }^{d}\end{array}$ & $\begin{array}{l}\text { Batch } \\
\text { ready }\end{array}$ & $\begin{array}{l}\text { Batch } \\
\text { delivered }\end{array}$ & $\begin{array}{l}\text { Sodium }^{8} \\
\text { (MT) }\end{array}$ & $\begin{array}{l}\text { Volumes } \\
\text { (ML) }\end{array}$ & $\begin{array}{c}\text { Delivery } \\
\text { time } \\
\text { (days) }\end{array}$ & $\begin{array}{c}\text { Process } \\
\text { time } e^{b . i} \\
\text { (days) }\end{array}$ & & $\begin{array}{l}\text { Sodium } \\
\text { (MT) }\end{array}$ & $\begin{array}{l}\text { Volume } \\
(\mathrm{ML})\end{array}$ \\
\hline \multirow{11}{*}{ A } & \multirow{2}{*}{1} & \multirow{2}{*}{$\begin{array}{l}\text { AN-105 } \\
\text { (Now) }\end{array}$} & \multirow{2}{*}{1090} & \multirow{2}{*}{4.13} & \multirow{2}{*}{1.45} & \multirow{2}{*}{-} & \multirow{2}{*}{$3 / 2001$} & \multirow{2}{*}{$6 / 2001$} & $12 / 2001$ & $12 / 2001$ & 514 & 2.63 & 3.6 & 222 & $1-\mathrm{Cl}$ & \multirow{2}{*}{1,027} & \multirow{2}{*}{5.25} \\
\hline & & & & & & & & & $12 / 2001$ & $12 / 2001$ & $\overline{513}$ & 2.62 & 3.6 & 225 & $1 . c 2$ & & \\
\hline & \multirow{2}{*}{2} & \multirow{2}{*}{7} & \multirow{2}{*}{1100} & \multirow{2}{*}{3.77} & \multirow{2}{*}{1.92} & \multirow{2}{*}{ - } & \multirow{2}{*}{$10 / 2001$} & $12 / 2001$ & $6 / 2002$ & $1 / 2003$ & 535 & 2.77 & 3.8 & 266 & $2-\mathrm{Cl}$ & 1070 & 554 \\
\hline & & & & & & & & 1दारण & $6 / 2002$ & $1 / 2003$ & 535 & 2.77 & 3.8 & 266 & $2-\mathrm{C} 2$ & $1,0 \mathrm{NO}$ & 3.54 \\
\hline & 3 & $\mathrm{AW}-101$ & 991 & 4.27 & 2.48 & - & $1 / 2003$ & $3 / 2003$ & $8 / 2003$ & $10 / 2003$ & 428 & 2.86 & 3.9 & 218 & $3=\mathrm{Cl}$ & 856 & 572 \\
\hline & & (Now) & 年 & & 2.40 & 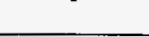 & & & $9 / 2003$ & $10 / 2003$ & 428 & 2.86 & 3.9 & 218 & $3-\mathrm{C2}$ & 850 & 5.72 \\
\hline & 4 & $A N-103$ & 1234 & 369 & & & & & $3 / 2004$ & $5 / 2004$ & 585 & 3.18 & 4.4 & 317 & $4-\mathrm{Cl}$ & & \\
\hline & 4 & (Now) & 1234 & 3.69 & 3.02 & - & $3 / 200 j$ & $10 / 2003$ & $3 / 2004$ & $5 / 2004$ & 585 & 3.18 & 4.4 & 317 & $4-\mathrm{C} 2$ & 1,170 & 6.36 \\
\hline & & $\begin{array}{l}\text { A.P-101 } \\
(4 / 1999)\end{array}$ & 745 & 4.18 & 0.45 & & & & 10/2004 & $3 / 2005$ & 575 & 2.87 & 3.9 & 288 & $5-\mathrm{Cl}$ & & \\
\hline & 5 & $\begin{array}{c}\mathrm{AW}-104 \\
(10 / 1999)\end{array}$ & 491 & 3.83 & - & - & $5 / 2004$ & $5 / 2004$ & $11 / 2004$ & $3 / 2005$ & 701 & 3.51 & 4.8 & 351 & $5-C 2$ & 1,276 & 6.38 \\
\hline & & Shim caustic & 380 & 0.87 & - & & & & & & & & & & - & & \\
\hline $\mathrm{P}$ & & $A Z-101$ & 359 & 3.12 & - & AY-101 & & & $8 / 2005$ & $1 / 2006$ & 118 & 1.05 & 1.4 & 59 & $6-\mathrm{Cl}$ & & \\
\hline 0 & 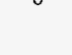 & $\mathrm{AZ}-102$ & 197 & 1.71 & - & $(1 / 2002)$ & $3 / 2005$ & $3 / 2003$ & $8 / 2005$ & $3 / 2006$ & 116 & 1.04 & 1.4 & $58^{\circ}$ & $6-C_{2}$ & 234 & 2.09 \\
\hline & $7^{\mathrm{h}}$ & & & & & & & & $1 / 2006$ & $3 / 2006$ & 119 & 0.74 & 1.0 & 29 & $7-\mathrm{Cl}$ & 238 & 148 \\
\hline & & AN-107 & $913^{\circ}$ & 4.26 & 1.41 & - & $1 / 2006$ & $1 / 2006$ & $3 / 2006$ & $5 / 2006$ & 119 & 0.74 & 1.0 & 29 & $7-\mathrm{C2}$ & 250 & 1.40 \\
\hline & $8^{\mathrm{h}}$ & (11/1997) & & & & & & & $1 / 2006$ & $4 / 2006$ & 272 & 1.69 & 2.3 & 137 & $8-\mathrm{Cl}$ & 544 & 3.38 \\
\hline & & & & & & & & & $3 / 2006$ & $6 / 2006$ & 272 & 1.69 & 2.3 & 137 & $8-\mathrm{C} 2$ & 544 & 3.50 \\
\hline & 9 & AN-102 & 1060 & 4.07 & 2.52 & - & $4 / 2006$ & $4 / 2006$ & $8 / 2006$ & $8 / 2006$ & 477 & 2.96 & 4.1 & 240 & $9-\mathrm{Cl}$ & & \\
\hline & & (Now) & & & & & & & $10 / 2006$ & $10 / 2006$ & 477 & 2.96 & 4.1 & 240 & $9-\mathrm{C} 2$ & 954 & 5.92 \\
\hline C & 10 & $A N-106$ & 846 & 4.32 & 0.95 & - & $8 / 2006$ & 82006 & $12 / 2006$ & $4 / 2007$ & 411 & 2.55 & 3.5 & 207 & $10-\mathrm{Cl}$ & 820 & 50 \\
\hline & & $(7 / 1999)$ & & t...2 & 0.00 & 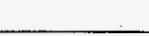 & 012000 & 0,2000 & $3 / 2007$ & $6 / 2007$ & 411 & 2.55 & 3.5 & 207 & $10-\mathrm{C} 2$ & $8<2$ & 3.10 \\
\hline & 11 & $S Y-10 \mathrm{I}$ & 1390 & 4.28 & 4.37 & $\begin{array}{l}\text { AN-102 } \\
A N-107\end{array}$ & $12 / 2005$ & 42007 & $8 / 2007$ & $11 / 2007$ & 615 & 3.82 & 5.2 & 306 & $11-\mathrm{Cl}$ & 1230 & \\
\hline & & (Now) & & 7.20 & & $(5 / 2006)$ & 1दI 2000 & 472007 & $10 / 2007$ & $1 / 2008$ & 615 & 3.82 & 5.2 & 306 & $11-C 2$ & 1,250 & 1.64 \\
\hline & 12 & . & & & & AN-102 & 120006 & $11 / 2007$ & $3 / 2008$ & 9/2008 & 452 & 2.81 & 3.8 & 256 & $12-\mathrm{Cl}$ & 700 & \\
\hline & & SY-103 (Now) & 718 & 2.79 & 1.67 & $(3 / 2008)$ & 1012000 & 10000 & $5 / 2008$ & $11 / 2008$ & 337 & 2.09 & 2.9 & 199 & $12-C 2$ & 109 & 4.90 \\
\hline
\end{tabular}

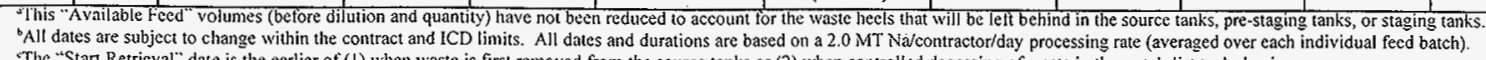

"The "Begin Straging"
"The "Batcll Ready" discis

"The "Batch Ready" datc is when the feed is ready for transfer to the private contractors' feed tanks (AP-106 or AP-108). The feed is qualified and is in AP-102 and AP-104.

The delivered quantity takes into account tank heels, dissolution of and scparation of solids and mass bot

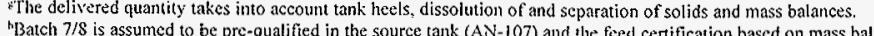

iThe "Process Time" shown in this table accounts for the 30 -day heel remaining in the private contractors 'feed tanks between feed batches of the same crrvelope.

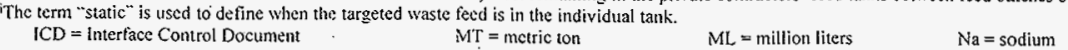


The estimated time required for staging feed batches was evaluated. All feed batches can be prepared within the available time. A summary of the evaluation for Envelope $A$ feed is presented in Table 15. Batch 7 was assumed to be prequalified in the source tank ( $\dot{A} N-107)$ because no subsequent blending or processing is required. Batch 7 contains supernate liquid from tank AN-107. The feed for this batch will be prequalified in the source tank using mass balances to determine the delivered composition if expected process improvements do not enable more rapid turnaround time.

Table 15. Typical Low-Activity Waste Feed Delivery Batch Cycle Time for Envelope A.

\begin{tabular}{|c|c|}
\hline Activity & Time (days) \\
\hline $\begin{array}{l}\text { Mobilize and retrieve low-activity waste fiom source tank } \\
\text { - Decant supematant with in-line dilution } \\
\text { Add dilution water and dissolve solids in-tank } \\
\text { - Mix tank and take process control samples } \\
\text { Decant dissolved solids }\end{array}$ & 69 \\
\hline $\begin{array}{l}\text { Adjust staged feed as required } \\
-\quad \text { Mix tank and take process control samples } \\
\text { - } \quad \text { Select feed adjustment and document } \\
\text { - }\end{array}$ & 28 \\
\hline $\begin{array}{l}\text { Feed qualification } \\
\text { - Mix tank and take feed qualification samples (for PHMC team and archive) } \\
\text { - } \quad \text { Provide samples to private contractor } \\
\text { - } \quad \text { Pralyze samples and issue sample qualification report } \\
\text { Provide feed qualification/certification repont to private contractors }\end{array}$ & 85 \\
\hline Total duration* & 182 \\
\hline
\end{tabular}

*From emptying tanks AP-102 and AP-10 of the previous batch to when the next batch is ready for delivery to the private contractors.

PFIMC $=$ Project Hanford Managenent Contrạct.

\subsubsection{Phase 1 Immobilized Low-Activity Waste Package Processing}

It is assumed that the private contractors' LAW immobilization plants will deliver waste packages to the TWRS ILAW Disposal Facility at an average rate during the Phase 1 mission (see Figure 7, hexagon indicator 2 , to see the relation of the LAW immobilization plants and the ILAW Disposal Facility).

Production estimates indicate that four to five packages per day will be transported from the private contractors to the disposal facilities. Peak transport rates could be as high as nine packages per day. Time and motion estimates indicate that each round trip will require approximately 3.5 hours per package. These estimates allow for the completion of radiation 
surveys, loading, transport, unloading, receipt radiation surveys, and return to the original location.. The number of operating shifts, operating trucks, and disposal. vault cranes is flexible enough to accommodate day-to-day variations in private contractor production rates.

Space requirements will be strongly influenced by private contractor startup date, production rates, and glass waste loading. The volume of ILAW that each contractor is allowed to return is limited by the glass waste loading. Waste loading limits are defined in the private contracts as: ". . . for every gram-mole of sodium provided to the contractor in waste Envelopes $\mathrm{A}$ and $\mathrm{C}$, the contractor may produce up to $100 \mathrm{~cm}^{3}$ of $I \mathrm{AW}$ product, based on external dimensions of the package $\left(250 \mathrm{~cm}^{3}\right.$ for Envelope B) ...." Guidance from the DOE was used as the planning basis. The contract provides incentives to reduce the total number of waste packages (i.e., increased waste loadings).

Figure 8 compares the baseline system $\amalg$ AW disposal capacity with the base case operating scenario and several sensitivity cases. The expected ILAW can be accommodated for essentially all reasonable cases. The analysis shows that additional stacking height and/or acceleration of the disposal facility addition schedule may be needed for certain operating scenarios.

The "base case operating scenario" is based on the specific feed planned to be delivered to the private contractors and conditions. This curve shows that additional stacking height or accelerated startup of the disposal facility addition (Project W-520) may be needed. Factors such as the ramp-up production of the plants and actual throughput rates add uncertainty in the projected ILAW receipts over time. The disposal requirements will be reevaluated as private contractor processing rates are finalized.

\subsubsection{Phase 1 High-Level Waste Feed Processing}

The TWRS HLW feed delivery sequence will be a process wherein waste is retrieved, prepared, and delivered to the private contractors' feed tanks (see Figure 7, hexagon indicator 3 ) in a series of batches throughout Phase 1. The TWRS HLW feed delivery for Phase $1 B$ is indicated in Table 16. Batches and corresponding envelope specifications are as indicated. Approximately 6 million liters (1.5 Mgal) of HLW feed will be processed during Phase 1 . With the assumption that the private contractor will take feed at an average rate during Phase 1 , the flow rate will average $0.164 \mathrm{MT}$ of nonvolatile oxide less sodium and silicon (NVOL) per day delivered to the private contractors. This rate includes the resource delays inherent in the TWRS waste feed delivery cycle and is approximately equal to a feed rate of $1.5 \mathrm{~L}(0.4 \mathrm{gal})$ per minute. 


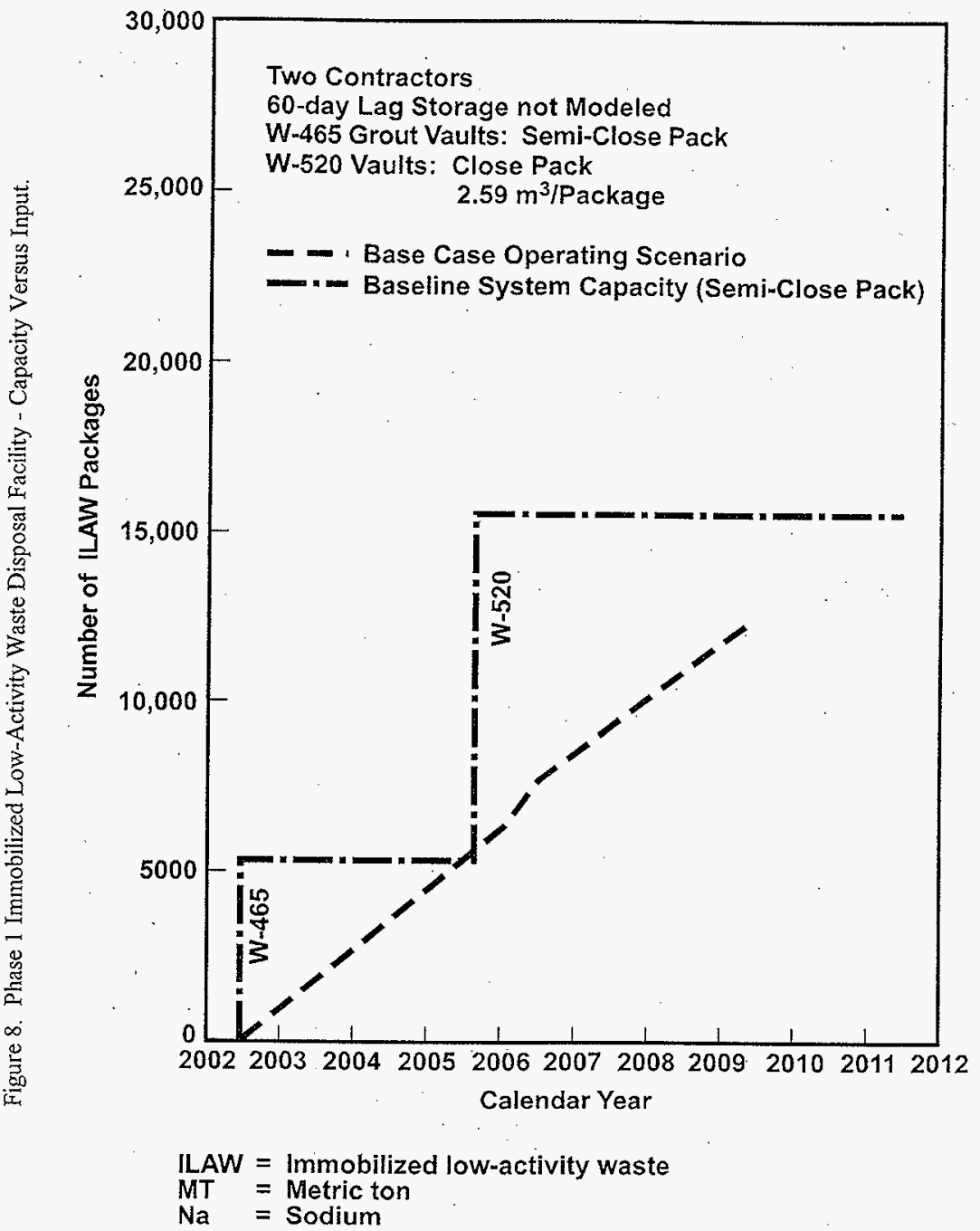

HG97110249.69

MAR-8 
The creation of HLW feed Envelope $D$ specifications was determined using process knowledge and analytical data from four source tanks: AZ-101, AZ-102, AY-102, and C-106. These tanks were selected as source tanks for HLW feed during Phase 1B. Tank C-104 was selected to provide the additional material needed to satisfy the maximum order quantity.

The composition of the conditioned sludge from each HLW source tank was determined using the best available tank characterization and process test (sludge washing) data. The sludgewashing process was tailored with the objective of satisfying the Envelope D composition limits. Laboratory process testing is planned to confirm the chemical behavior, physical properties, transport properties, and composition of the pretreated sludge.

The processing sequence was established by integrating existing project and retrieval activities and integration of tank usage with the operational waste volume projections. For example, tank AZ-101 was selected as the first source of HLW feed to take advantage of the mixer pumps that have already been installed by Project W-151, Tank AZ-101 Waste Retrieval System.

The sludge in tanks AZ-101 and AZ-102 will be conditioned and delivered directly from their source tanks to the HLW Immobilization Facility. Sludge from tank C-106 will be retrieved into tank AY-102 and then transferred to tank AZ-101 when tank space is available. The blend will be conditioned in tank AZ-101 and then delivered to the HLW Immobilization Facility. As soon as the conditioned sludge is removed from tank AY-102, sludge from tank C-104 will be retrieved into tank AY-102, and transferred to tank AZ-102 (when tank space is available), conditioned, and delivered to the HLW Immobilization Facility.

Table 16 summarizes the available quantities of $\mathrm{HLW}$ feed and how much is delivered to the private contractors. The operating scenario is durable enough to satisfy the minimum to maximum order quantities.

\subsubsection{Phase 1 Immobilized High-Level Waste Canister Processing}

It is assumed that the private contractors' HLW Immobilization Facility will deliver canisters of IHLW at an average rate to the TWRS CSB modules during Phase 1 processing. The volume of IHLW that the private contractors will be allowed to return will be limited by the minimum waste oxide loading imposed by the contracts: See hexagon indicator 4 in Figure 7 to see the relation of the HLW immobilization plant to the CSB. The CSB will have three cells, of which two will be reserved for TWRS. Staff at the Spent Nuclear Fuels Project will operate the CSB until they fill the first cell, then the TWRS Project will operate the CSB facility. 
Table 16. High-Level Waste Source Tanks and Feed Batches.

\begin{tabular}{|c|c|c|c|c|c|c|c|c|c|c|c|c|c|c|c|c|c|}
\hline \multirow{2}{*}{ Envelope } & \multirow{2}{*}{ Batch } & \multicolumn{3}{|c|}{ Available feed ${ }^{2}$} & \multirow{2}{*}{$\begin{array}{l}\text { Sluicing } \\
\text { receiver }\end{array}$} & \multirow{2}{*}{$\begin{array}{l}\text { Washing and } \\
\text { staging tank }\end{array}$} & \multicolumn{5}{|c|}{ Approximate timing ${ }^{b}$} & \multicolumn{2}{|c|}{$\begin{array}{l}\text { Total feed delivered from } \\
\text { source tank }\end{array}$} & \multicolumn{2}{|c|}{$\begin{array}{l}\text { Feed delivered } \\
\text { per batch }\end{array}$} & \multicolumn{2}{|c|}{$\begin{array}{c}\text { Feed delivered to } \\
\text { immobilization }\end{array}$} \\
\hline & & $\begin{array}{c}\text { Source } \\
\text { tank }\end{array}$ & $\begin{array}{l}\text { Quantity }^{\circ} \\
\text { (MT) }\end{array}$ & $\begin{array}{l}\text { Volume } \\
\text { (ML) }\end{array}$ & & & $\begin{array}{l}\text { Begin } \\
\text { sluicing }\end{array}$ & $\begin{array}{l}\text { Begin pre- } \\
\text { Stagings }\end{array}$ & $\begin{array}{l}\text { Begin pre- } \\
\text { treatment }\end{array}$ & $\begin{array}{l}\text { Batch } \\
\text { ready }\end{array}$ & $\begin{array}{l}\text { Batch } \\
\text { delivered }\end{array}$ & $\begin{array}{l}\text { Quantity } \\
\text { (MT) }\end{array}$ & $\begin{array}{l}\text { Volume } \\
\text { (ML) }\end{array}$ & $\begin{array}{l}\text { Quantity } \\
\text { (MT) }\end{array}$ & $\begin{array}{l}\text { Volume } \\
\text { (ML) }\end{array}$ & $\begin{array}{c}\text { Delivery } \\
\text { time (days) }\end{array}$ & $\begin{array}{c}\text { Process } \\
\text { time (days) }\end{array}$ \\
\hline \multirow{12}{*}{$\mathrm{D}$} & 1 & \multirow{2}{*}{ AZ-101 } & \multirow{2}{*}{96.4} & \multirow{2}{*}{0.18} & \multirow[b]{2}{*}{ - } & \multirow{2}{*}{$A Z-101$} & \multirow[b]{2}{*}{$=$} & \multirow[b]{2}{*}{ - } & \multirow{2}{*}{$10 / 2000$} & \multirow{2}{*}{$8 / 2001$} & $5 / 2002$ & \multirow{2}{*}{86.8} & \multirow{2}{*}{1.06} & 43.4 & 0.53 & 1 & 264 \\
\hline & 2 & & & & & & & & & & $2 / 2003$ & & & 43.4 & 0.53 & 1 & 264 \\
\hline & 3 & \multirow{2}{*}{$A Z-102$} & \multirow{2}{*}{161.5} & \multirow{2}{*}{0.39} & \multirow{2}{*}{ - } & \multirow{2}{*}{$A Z-102$} & \multirow{2}{*}{ - } & & \multirow{2}{*}{$4 / 2002$} & \multirow{2}{*}{$2 / 2003$} & $11 / 2003$ & \multirow{2}{*}{97.0} & \multirow{2}{*}{1.10} & 48.5 & 0.55 & 1 & 295 \\
\hline & 4 & & & & & & & 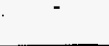 & & & $8 / 2004$ & & & 48.5 & 0.55 & 1 & .295 \\
\hline & 5 & \multirow{5}{*}{$A Y-102$} & \multirow{5}{*}{156.3} & & & & & & & & $6 / 2005$ & & & 32.9 & 0.49 & 1 & 200 \\
\hline & 6 & & & 0.08 & & & & & & & $1 / 2006$ & & & 32.9 & 0.49 & 1 & 200 \\
\hline & 7 & & & & AY-102 & AZ-101 & $10 / 1998$ & $6 / 2003$ & $6 / 2003$ & $4 / 2004$ & $7 / 2006$ & 165 & 2.45 & 32.9 & 0.49 & 1 & 200 \\
\hline & 8 & & & 0.75 & & & & & & & $2 / 2007$ & & & 32.9 & 0.49 & 1 & 200 \\
\hline & 9 & & & & & & & & & & $8 / 2007$ & & & 32.9 & 0.49 & 1 & 200 \\
\hline & 10 & & & & & & & & & & $3 / 2008$ & & & 46.9 & 0.54 & 1 & 285 \\
\hline & 11 & $C-104$ & 386.0 & 1.12 & AY-102 & AZ- 102 & $7 / 2004$ & $7 / 2005$ & $7 / 2005$ & $5 / 2006$ & $12 / 2008$ & 117 & 1.35 & 46.9 & 0.54 & 1 & 285 \\
\hline & 12 & & & & & & & & & & $10 / 2009$ & & & 23.5 & 0.27 & 1 & 143 \\
\hline
\end{tabular}

"The "Available Feed" volumes and quantities have not been reduced to account for the waste hells that will be left behind in the source tanks, pre-stagin
bAll dates are subject to change within the contract and ICD limits. All dates and durations are based on a constant 0.164 MT NVOU/day processing fate.

"The "Quach Ready" date is when the feed is ready for transfer to the private contractor's facility . These dates do not include the time required

eprocessing times are based on an assumed immobilization facility processing rate of $0.164 \mathrm{MT}$ of equivalent nonvolatile oxides per day.

ICD $=$ Interface Control Document.

$\mathrm{NVOL}=$ nonvolatile oxide less sodium and silicon 
The TWRS cells will be outfitted with equipment to receive and interim store the dry powdered cesium by-products and the IFILW originated by the HLW immobilization plant. Project W-464 will modify vaults 2 and 3 of the CSB to allow storage of the HIW packages. Vaults 2 and 3 of the CSB will provide space for 440 tubes that could hold 1,320 of the 3-m $(10-\mathrm{ft})$ canisters or 880 of the $4.5-\mathrm{m}(15-\mathrm{ft})$ canisters. These canisters can contain IHLW, cesium, or non-routine $\mathrm{HLW}$. The maximum ordẹ is expected to yield approximately 1,200 canisters (3 $\mathrm{m}[10 \mathrm{ft}]$ ) of IHLW for Phase 1.

Figure 9 compares the baseline system IHLW storage capacity with the base case operating scenario. The volume of IHLW that the private contractor is allowed to return is limited by the minimum waste oxide loading imposed by the contracts. Sensitivity cases are not shown because the entire IHLW storage capacity is brought on-line at the start of Phase $1 B$ processing (Project W-464). The required IHIW storage capacity was determined by using the maximum order quantity and minimum 25 wt $\%$ NVOL waste oxide loading. This requirement represents an upper boundary on needed IHLW storage capacity.

The maximum canister handling capacity is estimated at 1.35 canisters per day. The canister handing rate is determined by the package transporter from the privatization facilities to the IFLW Storage Facility, as well as the unloading system and facility cranes and control installed in the modified CSB.

The key consideration for IHLW storage availability is coordination of construction and operating schedules with the Spent Nuclear Fuels Project. This interface is being actively managed by the PHMC Team to accommodate recent changes for the Spent Nuclear Fuels Project and to maintain a June 2002 capability for accepting IHLW.

\subsection{TANK WASTE REMEDIATION SYSTEM FACLITIES REQUIRED FOR THE PHASE 1 MISSION}

\subsubsection{Tank Waste Remediation System Facilities' Life-Cycle Overview}

A facility life cycle generally has six major phases: program planning, preconceptual, conceptual, execution, O\&M, and closeout. The execution phase consists of three subphases: design, construction, and turnover. The closeout phase consists of two subphases: postoperations and surveillance and $\mathrm{D} \& \mathrm{D}$. Because different parts of the system can operate in different life-cycle phases, the entire system may have several phases in operation simultaneously. Some of the major TWRS facilities already exist. For these facilities, the preliminary life-cycle phases will not apply. Some of the major TWRS facilities will be modified to accommodate the mission. The modifications may involve elements of all of these life-cycle phases. 
Figure 9. Tank Waste Remediation System Canister Storage Building Modules, Phase 1 Capacity Versus Input.

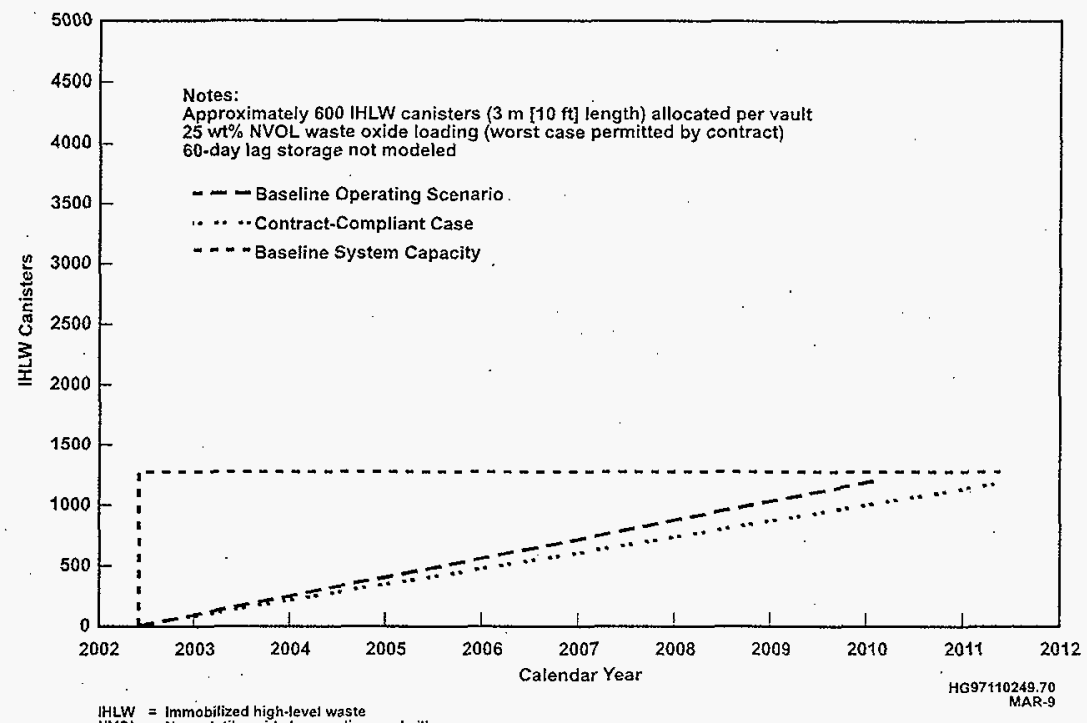

IHLW $=$ Immabilized high-level waste
NVOL = Nonvolațile oxioge less sodium and silicon

Each of the following phases can be defined to begin with and comprise identifiable activities as discussed below (GPG-FM-010, Project Execution and Engineering Management Planning).

- $\quad$ Program planning includes several levels of planning documents. The top-level document establishes the mission need documentation. Each successive level is more detailed and more narrowly focused. A graded approach is used to determine the key elements and the amount of detail required for development of each specific TWRS facility.

- The preconceptual phase establishes mission needs, preliminary functions, and requirements for the facility or facility modification, and critical review points for the facility development. 
- The conceptual phase is the first formal project phase. This phase develops design concepts and the basis for initiation of preliminary designs, and establishes project baselines for TWRS facilities such as the ILAW Storage and Disposal Facility, the interim HLW Storage Facility, infrastructure support facilities, and storage systems upgrades.

- The execution phase begins with planning for the detailed design and construction of systems for tank waste storage, upgrades and for waste retrieval, treatment, immobilization, and disposal. This phase will be complete when required facilities and systems have been constructed and turned over to TWRS for operations.

- The O\&M phase has already begun for the TWRS storage systems. For new facilities, the O\&M phase begins with operation of systems to support initial waste retrieval. This phase will be complete when tank waste and waste by-products have been retrieved, treated, immobilized, and disposed of.

- The closeout phase includes RCRA closure of waste tanks; D\&D of excess facilities, transfer piping, etc; and post-closure activities. The end of this phase will be defined by installation of long-term monitoring equipment for the ILAW sites and for the closed underground storage tanks.

\subsubsection{Phase 1 Mission - Required Facilities}

The TWRS facilities that are required for Phase 1 of the mission and their current lifecycle phase are briefly described as follows.

- The SST System will be used in Phase 1 mission activities. The SST System is in the latter stages of its O\&M phase.

- The DST System will be used in Phase 1 of the mission. The DST System is in the O\&M phase of its life cycle. Retrieval modifications will carry parts of the DST System back into the planning, preconceptual, conceptual, and project execution phases.

- The LAW Plant, Phase 1, is planned to be used in Phase 1 of the mission. It is not constructed and is considered to be in the planning phase of its life cycle.

- The LAW/HLW Plant, Phase 1, is planned to be used in Phase 1 of the mission. It is not constructed and is considered to be in the planning phase of its life cycle. 
- The ILAW Disposal Facility is planned to be actively used during the TWRS Phase 1 mission. Current plans call for renovation of the existing grout vaults to make them usable for $\Pi \mathrm{LAW}$ storage. The renovation/construction of this facility has not begun and the facility is considered to be in the conceptual phase of its life cycle.

- The ILAW Disposal Facility addition will be used during the latter part of the TWRS Phase 1 mission and will be used for the entire Phase 2 mission. At the end. of the Phase 2 mission, the facility is planned to become passive and provide onsite disposal of the ILAW. This facility is in the planning phase of its life cycle.

- The CSB, when outfitted with the TWRS CSB modules, Phase 1, will be used during the TWRS Phase 1 mission. The CSB is in the project execution phase of its life cycle.

Project W-519 is providing basic infrastructure services for the private contractors in accordance with the Interface Control Documents that the DOE has negotiated with the private contractors. New infrastructures or modifications to the existing infrastructures, required as a consequence of new facilities or facility modifications that the PHIMC Team provides for the Phase 1 mission, will be provided by these same PHMC projects.

Figure 10 shows a summary schedule for the planned life cycles for identified Phase 1 and Phase 2 facilities.

\subsubsection{Phase 1 Mission Facilities' Functional Requirements}

Top-level functions have been assigned to each TWRS major facility required for the Phase 1 mission. These are currently captured in the TWRS Technical Baseline contained in the HSTD. Table 17 lists the functional requirements that are associated with these major TWRS facilities. These functional requirements also will be used in the major TWRS facility specifications documents.

\subsubsection{Equipment Upgrades and New Facilities to Support Phase 1B}

This section discusses the upgrades and new facilities required to support mobilization of the wastes, waste delivery to the private contractors via the intermediate staging tanks, and eventual storage and/or disposal of the immobilized products. As previously discussed, the feed delivery requirements were analyzed and used to select tanks that contained the desired feed envelope wastes. The equipment in these tanks was then evaluated to determine upgrade requirements to mobilize the waste. The associated transfer pipelines were evaluated to determine upgrades required to move the wastes to feed staging tanks. Finally, private contractor processing rates were used to determine the timing and scope of storage and disposal facilities. 
Figure 10. Tank Waste Remediation System Facility Life Cycles:

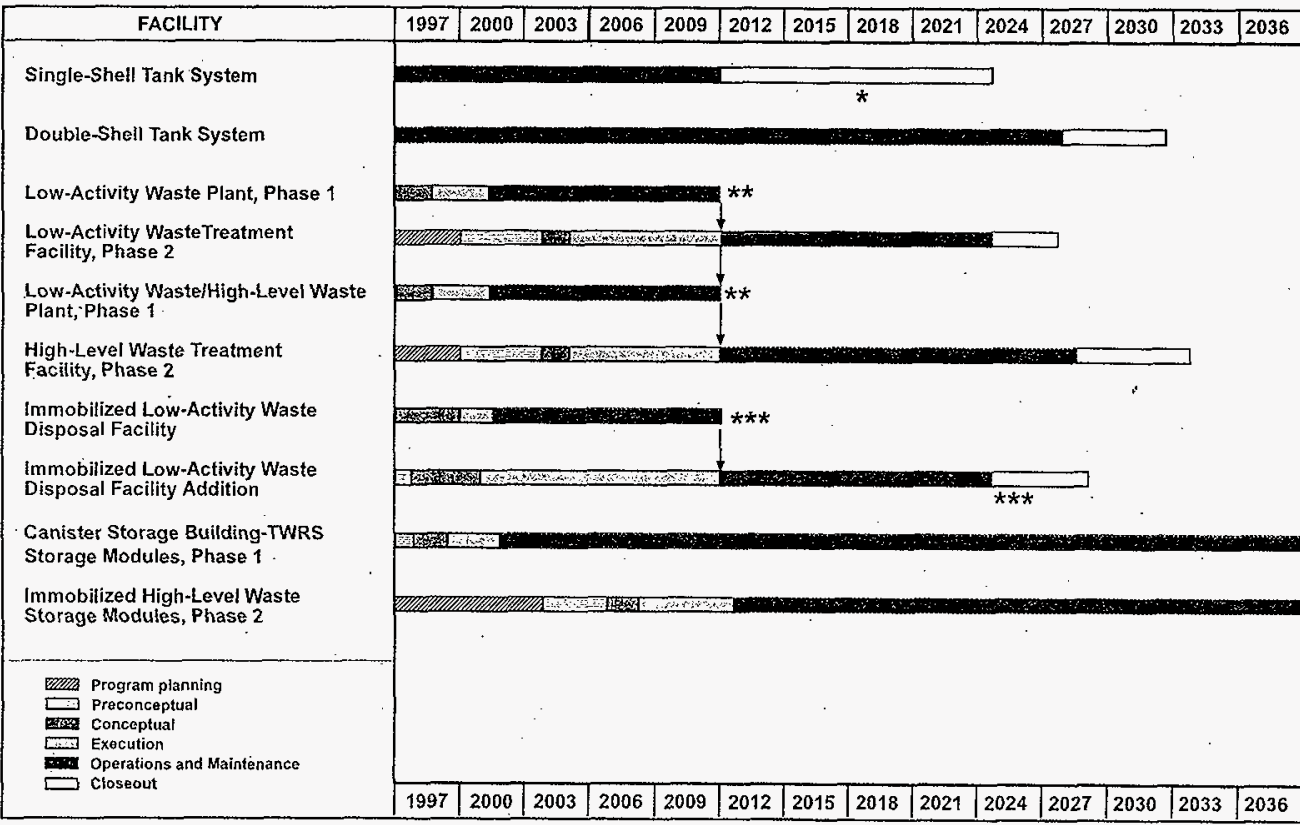

* Retrieval of single-shell tanks complete September 28, 2018.

** The decision to expand, continue usage, or close the private contractor facilities is not made yet.

HG97110249.11
MAR-10

*** Closure of disposal facilities occurs when operations are complete.

**** Immobilized high-level waste will be removed by October 2043 , if the national geologic repository is ready.

TWRS = Tank Waste Remediation System

Source: Lenseigne, D. L., 1997, Tank Waste Remediation System Fiscal Year 1998 Multi-Year Work Plan WBS 1.1,

HNF-SP-1230, Rev. 0, prepared by Lockheed Martin Hanford Corporation for Fluor Daniel Hanford, Inc., Richland, Wash ington. 


\section{Table 17. Tank Waste Remediation System Major Facilities Top-Level Functional Requirement Descriptions. (3 sheets)}

\begin{tabular}{|c|}
\hline SST System \\
\hline $\begin{array}{l}\text { The SST System will store and transfer wastes to maintain existing SST wastes in a safe and compliant manner. Safe } \\
\text { and compliant waste maintenance continues until wastes from the SSTs have been removed and the SST System } \\
\text { transition activities have been completed. }\end{array}$ \\
\hline $\begin{array}{l}\text { The Tank Waste Characterization System will take waste samples from the SSTs and analyze them to provide waste } \\
\text { information for current and future mission activities (e.g., storage, retrieval, transfer). }\end{array}$ \\
\hline $\begin{array}{l}\text { The SST System will remove wastes from the SSTs and transfer them to the DST System for further waste processing. } \\
\text { This activity is complete when wastes from the SST System have been removed and transferred to the DST System. }\end{array}$ \\
\hline $\begin{array}{l}\text { The SST System will perform the activities necessary to place the system components into a safe, stable, and } \\
\text { environmentally sound condition pending tinal disposition. }\end{array}$ \\
\hline The SST System will be maintained in a safe and compliant mode until tumover to the D\&D phase. \\
\hline $\begin{array}{l}\text { At the completion of the operational mission, the SST System will provide for decontamination of its system } \\
\text { components and soils. SST Operable Units will be closed and remaining SST components appropriately } \\
\text { dispositioned. }\end{array}$ \\
\hline DST System \\
\hline $\begin{array}{l}\text { The DST System will remove DST waste and send it for evaporation or for relocation to another DST for ștorage or } \\
\text { treatment. }\end{array}$ \\
\hline $\begin{array}{l}\text { The DST System will store existing tank waste and will accept and store additional waste from the } 100 \mathrm{~K} \text { Area, } \\
100 \mathrm{~N} \text { Area, T Plant, Plutonium Finishing Plant, 222-S Laboratories, } 242-\mathrm{A} \text { Evaporator, B Plant, } 300 \mathrm{Area}, \\
400 \text { Area, LAW treatment plant, and the HLW treatment plant waste generators. }\end{array}$ \\
\hline The DST System will prepare LAW feed from tank wastes and send the LAW to the immobilization system. \\
\hline The DST System will separate HLW from tank wastes and send the HLW to the immobilization system. \\
\hline $\begin{array}{l}\text { The DST System will process tank waste into a state suitable for feeding to Phase } 2 \text { treatment and immobilization } \\
\text { systems. }\end{array}$ \\
\hline $\begin{array}{l}\text { The Tank Waste Characterization System will take waste samples from the DSTs and analyze them to provide waste } \\
\text { information for current and future mission activities (e.g., storage, retrieval, transfer). }\end{array}$ \\
\hline $\begin{array}{l}\text { The DST System will perform the activities necessary to maintain the system components into a safe, stable, and } \\
\text { environmentally sound condition pending final disposition. }\end{array}$ \\
\hline The DST System will be maintained in a safe and compliant mode until turnover to the D\&D phase. \\
\hline $\begin{array}{l}\text { At the completion of the operational mission, the DST System will provide for decontamination of its system } \\
\text { components and soils. DST Operable Units will be closed and remaining DST components appropriately } \\
\text { dispositioned. }\end{array}$ \\
\hline
\end{tabular}




\section{Table 17. Tank Waste Remediation System Major Facilities Top-Level Functional Requirement Descriptions. (3 sheets)}

LAW Plant - Phase I
The LAW Plant - Phase I will receive and treat wastes delivered by the DST System and immobilize the low-activity
fraction of the treated waste. The LAW Plant - Phase I will package the ILAW and transfer it to the ILAW Storage
Facility. The LAW Plant - Phase I will transfer waste products resulting from the treatment/immobilization process
back to the DST System for storage and future disposition. Separated cesium will be loaded into canisters and
transferred to the TWRS CSB modules, Phase I for storage.

The LAW Plant - Phase I will perform the activities necessary to maintain the system components into a safe; stable, and environmentally sound condition pending final disposition.

The LAW Plant - Phase 1 will be maintained in a safe and compliant mode until turnover to the D\&D phase.

At the completion of the operational mission, the LAW Plant - Phase 1 will provide for decontamination of its system components and soils.

$$
\text { LAW/HLW Plant - Phase } 1
$$

The LAW/HLW Plant - Phase I will receive and treat waste delivered by the DST System, which includes an LAW stream and an HLW stream. The LAW stream will be treated and the I.AW fraction will be immobilized. The HLW streams from the DST System and LAW treatment will be immobilized. The LAW/HLW Plant - Phase I will package ILAW and transfer it to the ILAW Storage Facility. The LAW/HLW Plant - Phase 1 will package and seal IFILW containers, decontaminate the IHIL W. primary container outer surfaces, and test the integrity of the sealed containers. The LAW/KILW Plant - Phase I will load IHLW onto the transport mechanism and the IHLW will be transferred to the TWRS CSB modules, Phase I for interim storage. Waste products not immobilized will be returned to the DSI System for storage.

The LAW/HLW Plant - Phase 1 will perform the activities necessary to place the system components into a safe, stable, and environmentally sound condition pending.final disposition.

The LAW/LEW Plant - Phase 1 will be maintained in a safe and compliant mode until turnover to the D\&D phase. At the completion of the operational mission, the LAW/HLW Plant - Phase I will provide for decontamination of its system components and soils.

$$
\text { ILAW Disposal Facility }
$$

The ILAW Disposal Facility will transport ILAW from the private contractor facilities, receive, unload, emplace, and store sealed containers of ILAW from the Phase 1 LAW and LAW/HLW Plants. The ILAW Disposal Facility will monitor, control containment, and handle the ILAW for the long-term disposal.

The ILAW Disposal Facility will provide onsite disposal of ILAW.

The ILAW Disposal Facility will perform the activities necessary to place the system components into a safe, stable, and environmentally sound condition pending final disposition. 
Table 17. Tank Waste Remediation System Major Facilities Top-Level Functional Requirement Descriptions. (3 sheets)

ILAW Disposal Facility Addition

The ILAW Disposal Facility addition will transport ILAW from the private contractor facilities, receive, unload, emplace, and store sealed containers of ILAW from the Phase 1 and Phase 2 LAW and HILW Plants. The ILAW Disposal Facility addition will monitor, control containment, and handle the ILAW for the long-term disposal.

The ILAW Disposal Facility addition will provide onsite disposal of $\mathrm{LAW}$.

The ILAW Disposal Facility addition will perform the activities necessary to place the system components into a safe, stable, and environmentally sound condition pending final disposition.

The ILAW Disposal Facility addition will be placed into a final state such that it becomes the final disposal site for ILAW.

CSB: TWRS CSB modules - Phase 1 .

The TWRS CSB modules will ieceive, unload, emplace, and store sealed canisters of IHL W from the Phase 1 LAW/EULW Plant. The TWRS CSB modules will receive, unload, emplace, and store sealed canisters of separated cesium from the Phase 1 LAW Plants.

The CSB facility will monitor the interim-stored IFLW and cesium canisters for containment integrity during storage.

The CSB will prepare and load out stored cesium for transport to the Phase $2 \mathrm{HLW}$ Treatment Facility. The CSB will prepare and load out stored IHLW for transport to the national repository.

$\mathrm{CSB}=$ Canister Storage Building.

$\mathrm{D} \& \mathrm{D}=\mathrm{dccontamination}$ and decommissioning.

DST $=$ double-shell tank.

HLW $=$ high-level waste.

IHI. $W=$ immobilized high-level waste.

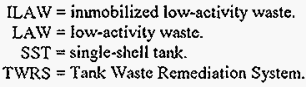

ILAW = intmobilized low-activity waste.

$\mathrm{LAW}=$ low-activity waste

SST = single-shell tank.

TWRS = Tank Waste Remediation System.

The results of these evaluations were used to define requirements for new or modified systems required to support Phase $1 \mathrm{~B}$. These requirements have been divided into 11 construction projects, as discussed in Section 10.3.4.1.

10.3.4.1 Equipment Upgrades and New Facilities Construction Projects. Four construction projects are scheduled for completion in FY 1998. These projects provide two new cross-site waste transfer lines (W-058), improve the aging waste tanks' ventilation system (W-030), provide equipment to remove waste from SST C-106 (W-320), and provide mixer pumps for

DST AZ-101. To meet the rest of the Phase 1B feed delivery, infrastructure, storage, and transfer systems upgrades, and waste disposal and interim storage requirements, seven additional construction projects have started or are being planned.

Three of these construction projects are designed to ensure feed to the private contractors. Project W-211, Initial Tank Retrieval Systems, Project W-314, Tank Farm Restoration and Safe Operations, and a new project, W-TBD, include the addition of mixer pumps (and other equipment necessary to mobilize the feed), transfer systems to move the feed to the staging tanks, and add tank sludge-washing capability. Project W-TBD was scoped to include additional transfer systems and other equipment not yet included in Projects W-211 and W-314. 
Three additional construction projects provide the transfer, storage, and disposal facilities for the immobilized products. Project W-465, LAW Disposal Project, provides facilities for receipt and disposal of LAW in modified grout vaults. Project W-520, the follow-on project for W -465 , provides additional disposal capacity for the balance of the Phase $1 B \mathrm{LAW}$ product. Project W-464, Interim HLW Storage, provides facilities for receipt and interim storage of HLW products.

Construction Project. W-519, Privatization Phase 1 Infrastructure, provides utilities (raw and potable water, electrical and effluent transfer lines), roads, and site development work to support the infrastructure needs of the private contractors for Phase $1 B$.

Table 18 presents a summary of the overall project scope, schedule, and costs necessary to support Phase IB. More detailed discussions of the scope of each project, schedules, budgets, critical risks, and enabling assumptions are presented in the Tank Waste Remediation System Program Plan (Freeman 1998).

10.3.4.2 Risk Issues for the System Upgrades Supporting Phase 1B. Risks associated with project activities have been identified and mitigation plans have been developed. A list of the project risks and the mitigation plans is included in the Risk Lists associated with the Tank Waste Remediation System Risk Management Plan (Zimmerman 1998).

\subsection{PHASE 1 MISSION CONCLUSIONS}

Analyses that were conducted are detailed in the Tank Waste Remediation System Operation and Utilization Plan (Kirkbride et al. 1997). The operating scenario was developed and analyzed using applicable requirements from the private contracts and assumptions were established for key information that was not currently available.

The operating scenario delivers appropriate quantities and composition of LAW and HUW feed at the proper time, provide tank space to accept the returned "entrained solids and separated ${ }^{90} \mathrm{Sr} / T R U$," provide adequate storage capability for the storage and disposal of ILAW, provide adequate storage capability for the interim storage of $I H \amalg W$, and manage these activities within existing tank space.

The physical system required to support Phase $1 B$ by the TWRS organization in the 200 Area was defined and is understood. The evaluation of the existing system against the required system identified the gaps and vulnerabilities. Several projects, which are in various stages of completion, will provide the new or modified systems needed to eliminate the identified gaps and vulnerabilities. The design, procurement, construction, testing, and startup activities for these projects will be accomplished in time to support the June 2002 initial feed delivery date. 
Table 18. Summary of the Construction Projects' Scope, Schedules, and Costs. (2 Sheets)

\begin{tabular}{|c|c|c|c|}
\hline Project no./title & Scope & Schedules & Costs (TPC) \\
\hline $\begin{array}{l}\text { W- } 058 \\
\text { Cross-Site } \\
\text { Transfer System }\end{array}$ & $\begin{array}{l}\text { Provide two new transfer lines from } \\
200 \text { West to } 200 \text { East, including } \\
\text { associated mechanical equipment and } \\
\text { instrumentation }\end{array}$ & $\begin{array}{l}\text { The Project will be } \\
\text { completed in FY } 1998\end{array}$ & TPC $\$ 49.3$ million \\
\hline $\begin{array}{l}\text { W-030 } \\
\text { Tank Farm } \\
\text { Ventilation } \\
\text { Upgrade }\end{array}$ & $\begin{array}{l}\text { Install new ventilation systems on the } \\
\text { Aging Waste Tanks, AZ and AY tank } \\
\text { farms }\end{array}$ & $\begin{array}{l}\text { The Project will be } \\
\text { completed in FY } 1998\end{array}$ & $\mathrm{TP}^{\mathrm{C}} \$ 47.9$ million \\
\hline $\begin{array}{l}\text { W-320 } \\
\text { Tank C-106 } \\
\text { Sluicing }\end{array}$ & $\begin{array}{l}\text { Provide equipment and facilities } \\
\text { modifications to mobilize contents of } \\
\text { tank C-106 and transfer contents to } \\
\text { tank AY-102 }\end{array}$ & $\begin{array}{l}\text { Construction will be } \\
\text { completed and sluicing } \\
\text { initiated in FY } 1998\end{array}$ & TPC $\$ 85.6$ million \\
\hline $\begin{array}{l}\text { W-151 } \\
\text { Tank 101-AZ } \\
\text { Waste Retrieval } \\
\text { System }\end{array}$ & $\begin{array}{l}\text { Provide two mixer punps and } \\
\text { ancillary equipment for mobilizing the } \\
\text { sludge in tank AZ-101 }\end{array}$ & $\begin{array}{l}\text { The Project will be } \\
\text { completed in FY } 1998\end{array}$ & TPC $\$ 27.7$ million \\
\hline $\begin{array}{l}\text { W-211 } \\
\text { Initial Tank } \\
\text { Retrieval System }\end{array}$ & $\begin{array}{l}\text { Mobilization and transfer systems for } \\
\text { waste retrieval in ten tanks }\end{array}$ & $\begin{array}{l}\text { FY 1996-2005. } \\
\text { First feed tank AN-105, } \\
\text { design start in } \\
\text { October } 1997 \text {, operational } \\
\text { March } 2001\end{array}$ & $\$ 229$ million \\
\hline $\begin{array}{l}\text { W-314 } \\
\text { Tank Farm } \\
\text { Restoration and } \\
\text { Safe Operations }\end{array}$ & $\begin{array}{l}\text { Provide infrastructure upgrades to the } \\
\text { tank farms }\end{array}$ & $\begin{array}{l}\text { Phase I FY 1997-2000 } \\
\text { Phase } 22001-2024\end{array}$ & $\begin{array}{l}\text { Phase } 1 \$ 70 \text { million } \\
\text { Phase } 2 \$ 230 \\
\text { million }\end{array}$ \\
\hline $\begin{array}{l}\text { W-TBD } \\
\text { New project }\end{array}$ & $\begin{array}{l}\text { Sludge-washing capability in tank } \\
\text { AZ-101 and four additional DST } \\
\text { retrieval and transfer systems }\end{array}$ & $\begin{array}{l}\text { AZ-101 portion FY 1998- } \\
2001, \text { W-211 follow-on } \\
\text { FY 1998-2004 }\end{array}$ & $\$ 76$ million \\
\hline $\begin{array}{l}\text { W-464 } \\
\text { Interim High- } \\
\text { Level Waste } \\
\text { Storage }\end{array}$ & $\begin{array}{l}\text { Receipt and interim storage of the } \\
\text { HLW in the modified Canister Storage } \\
\text { Building }\end{array}$ & $\begin{array}{l}\text { Design start FY } 2000 \\
\text { Construction FY } 2001 \\
\text { Operational June } 2002\end{array}$ & $\$ 42$ million \\
\hline $\begin{array}{l}\text { W-465 } \\
\text { Low-Activity } \\
\text { Waste Disposal }\end{array}$ & $\begin{array}{l}\text { Receipt and disposal of LAW in } \\
\text { modified grout vaults }\end{array}$ & $\begin{array}{l}\text { Design start FY } 2000 \\
\text { Construction FY 2001 } \\
\text { Operational June } 2002\end{array}$ & $\$ 43$ million \\
\hline $\begin{array}{l}\text { W-S19 } \\
\text { Privatization } \\
\text { Phase L } \\
\text { Infrastructure }\end{array}$ & $\begin{array}{l}\text { Provide infrastructure for private } \\
\text { contractors }\end{array}$ & FY 1998-2001 & $\$ 39$ million \\
\hline
\end{tabular}


Table 18. Summary of the Construction Projects' Scope, Schedules, and Costs: (2 Sheets)

\begin{tabular}{|l|l|l|l|}
\begin{tabular}{|l|l|} 
W-520 \\
LAW Disposal
\end{tabular} & $\begin{array}{l}\text { Balance of Phase I LAW disposal } \\
\text { capacity }\end{array}$ & $\begin{array}{l}\text { Design start FY 2001 } \\
\text { Construction FY 2003 } \\
\text { Operation FY 2004/2005 }\end{array}$ & $\$ 84$ million \\
\hline $\begin{aligned} \text { DST }=\text { double-shell tank. } \\
\text { FY }=\text { fiscal year. } \\
\text { HLW }=\text { high-level waste. }\end{aligned}$ & $\begin{array}{l}\text { LAW }=\text { low-activity wastc. } \\
\text { TBD }=\text { to be determincd. }\end{array}$ \\
TPC = total project cost.
\end{tabular}

\subsubsection{Feed Staging Conclusions and Recommendations}

The operating scenario for feed staging was found to deliver appropriate quantities and composition of LAW and HLW feed at the proper time, provide tank space to accept the returned "entrained solids and separated ${ }^{90} \mathrm{Sr} / \mathrm{TRU}$," provide adequate storage capability for the storage and disposal of ILAW, provide adequate storage capability for the interim storage of IHLW, and manage these activities within existing tank space.

It is recommended that $R L$ consider the direct transfer of existing waste in: tanks AP-106 and AP-108 to the private contractors. This would reduce the complexity of the feed transfer operations and result in significant cost savings.

The following recommendations should increase the robustness of the feed delivery system and reduce risks and the overall cost of the Phase $1 \mathrm{~B}$ mission. It is recognized that these recommendations may require contract negotiation. The complete discussion of these recommendations is provided in the Tank Waste Remediation System Operation and Utilization Plan (Kirkbride et al. 1997).

- Impose a minimum time duration between the completion of the delivery of one feed batch and the waste transfer date for the following batch. This provides the RL/TWRS contractor with sufficient time to stage feed, regardless of high processing rates and/or small feed batches.

- Allow the PHMC Team to complete delivery of the feed batch that reaches a minimum order quantity even if this means that the minimum order quantity will be exceeded. This enables the TWRS contractor to free up usable DST space as fast as possible by allowing full tanks of waste to be retrieved and delivered and avoids having to deal with "odd-lot" sized batches. The contracts imply that the minimum order quantities need to be delivered exactly--no more and no less. This recommendation will provide a range to deliver slightly more than the minimum order quantities to ensure that the minimum order quantities are met. 
- Reduce the minimum size of the first LAW feed batch. Reducing the minimum size of the first feed batch will reduce the risk that the first feed batch will be short and the need (and associated costs) to blend or shim the first feed batch to satisfy this limit.

- Minimize the number of analytes and physical properties to be analyzed for Envelope $D$ to include only those components that are considered significant to the performance of the immobilization process. This will minimize time durations to complete laboratory analysis, avoid laboratory instrumentation upgrade costs, and provide additional schedule contingency.

- Develop a compensation model for processing off-specification feed and include this provision in the privatization contracts. This provides $\mathrm{RL}$ with options that ${ }^{\circ}$ reduce the overall cost and schedule impacts of ensuring that delivered feed satisfies the envelopes. If a feed batch cannot be certified as meeting the appropriate envelope limits, this provides RL with the option to deliver as-is and avoid potential schedule impacts and/or contract disputes.

- Refine the LAW envelope limits for aluminum, sulfate, total organic carbon, TRU waste, and ${ }^{90} \mathrm{Sr}$. Also, modify the current definition of Envelope $\mathrm{D}$ (and the expanded design basis), specifically for the maximum concentrations of aluminum and silver. These refinements increase the robustness of the operating scenario by providing greater flexibility in selecting and staging feed, reducing the potential need to blend and/or shim feed and allow better use of existing feed sources. The risks of not delivering the proper composition of feed are reduced along with the potential costs to RL from risk mitigation.

- Include a new combined minimum order quantity for Envelopes A, B, and C. Reduce the minimum order quantity of Envelope $\mathrm{A}$. These two recommendations taken together provide flexibility in selecting feed that satisfies the minimum order quantities of Envelopes A, B, and C and provide additional flexibility in scheduling construction projects.

\subsubsection{Tri-Party Agreement Milestones for Early Phase 2 Single-Shell Tank Retrieval}

The existing TWRS retrieval and disposal baseline plans do not meet 5 of 15 Tri-Party Agreement target dates for initiating waste retrieval from SSTs. The current planning base (Kirkbride et al. 1997) has SST retrieval completing in 2020, thus also missing the 2018 interim milestone date. Waste processing, however, is completed by the Tri-Party Agreement milestone dates.

Retrieval of 36 SSTs through September 2010 (i.e., during Phase 1 of the TWRS privatization initiative) will not be possible because sufficient DST space will not exist to store the volume of waste that would result from retrieval of 36 SSTs. The amount of waste processed 
(removed from DSTs) during Phase 1 must be increased to make additional space in DSTs to accommodate waste from SST retrieval (i.e., process more than $13 \%$ of tank waste during Phase 1).

After 2011 (when large Phase 2 waste immobilization plants are expected to be operating), waste retrieval from as many as ten SSTs simultaneously is planned, and SST retrieval is not completed until 2020. The rate of SST retrieval during Phase 2 is limited by the planned tank farm configuration and by operating constraints that limit the rate of SST retrieval. Challenges associated with waste retrieval from tanks that have leaked further complicate the retrieval plans. An analysis of SST retrieval is being planned to develop program plans that meet Tri-Party Agreement milestones and can reasonably be expected to be achieved given technology, logistic, and safety, health, and environmental concerns.

\subsubsection{Phase 1 Summary and Conclusions}

An overall systems approach was applied to develop action plans to support the retrieval and disposal mission. The systems approach included defining the TWRS Project mission requirements and evaluating the readiness of TWRS to initiate waste feed supply and provide storage and disposal facilities for immobilization of high- and low-level waste to the private contractors in. June 2002. The Phase $1 \mathrm{~B}$ feed delivery requirements from the private contractor Requests for Proposal were reviewed. Transfer piping routes were mapped, existing systems were evaluated, and upgrade requirements were defined. The TWRS personnel training, qualifications, management systems, and procedures were reviewed and shown to be in place and ready to support Phase $1 \mathrm{~B}$. Key assumptions and risks that could negatively impact mission success were evaluated and appropriate actions were planned and scheduled.

The analysis concluded that the systems and infrastructure required to support the mission have been identified. Required systems are in place or plans have been developed to ensure that they will exist when needed. The analysis showed that since October 1996, a robust systems approach has been developed, integrating Technical Baselines, WBS's, tank farm structure, and engineering configurations. An analysis of programmatic, management, and technical activities necessary to declare readiness to proceed with execution of the mission showed that the systems, personnel, and hardware will be on line and ready to support the mission. 


\subsection{PHASE 2 MISSION TECHNICAL STRATEGY}

\subsection{PHASE 2 INTRODUCTION}

Phase 2 operations can be separated into the following four categories (Kirkbride et al. 1997):

- Retrieval of the SSTs (by sluicing as a reference, although some tanks may require alternate methods)

- Operation of the DST System as a receiving facility for retrieved SST waste and a staging facility for waste separation and waste preparation operations

- Pretreatment and treatment (immobilization) operations in contractor-provided facilities

- Storage and disposal of the ILAW and the IFILW.

Major challenges associated with retrieval of waste from the 149 SSTs can be categorized into two major areas: retrieval technology and retrieval rate. The baseline retrieval technology, hydraulic sluicing, will convert the approximately 132.5 million liters ( $35 \mathrm{Mgal}$ ) of waste currently stored in the SSTs into approximately 435.3 million liters (115 Mgal) of slurry. Sixty-seven of the SSTs have been declared leakers and hydraulic sluicing of these tanks may not be appropriate due to possible contamination of the surrounding environment

The Phase 1 mission will retrieve tanks at an average retrieval rate of four tanks per year. In Phase 2, the average retrieval rate could increase up to 13 tanks per year. To achieve these retrieval rates, simultaneous sluicing of up to 11 tanks per year could be required. These retrieval rates assume a 24 hour/day, 365 day/year operation.

\subsection{PHASE 2 MISSION TECHNICAL STRATEGIES}

In addition to those technical strategies specified in Sections 8.0 and 8.1, the following technical strategies ( 62 FR 86,93) were developed to meet these challenges and to achieve the mission.

- Construct full-scale processing facilities to immobilize LAW and immobilize HLW.

- Install and operate tank retrieval systems to retrieve waste from SSTs, DSTs, and MUSTs.

- $\quad$ Pretreat the waste to produce an $\mathrm{LAW}$ fraction and an HLW fraction. 
- Perform separations to remove selected radionuclides from the LAW feed stream and transfer them to the HLW Vitrification Facility.

- Immobilize the HLW stream and the LAW stream.

- Package the HLW in canisters for onsite interim storage and future shipment to the national geologic repository.

- $\quad$ Place the ILAW in containers and place the containers in onsite near-surface disposal facilities.

The FY 1995 Hanford Mission Plan (RL 1994) adds the following to the Phase 2 technical strategy:

- In-place disposal of the residual waste that remains in the tanks after retrieval operations, the in-tank equipment, the tank structures, and any underlying or adjacent contaminated soils using suitable treatment methods that have been determined through performance assessments that establish tank closure requirements

- Blending the contents of the cesium ard strontium capsules with other tank waste, vitrifying the waste into a canistered borosilicate glass form, and storing the vitrified waste for eventual disposal at a geologic repository.

\subsection{PHASE 2 MISSION GOALS, OBJECTIVES, AND MEASURES OF SUCCESS}

\subsection{PHASE 2 MISSION GOALS AND OBJECTIVES}

The primary goals and objectives for the Phase 2 mission are derived from the Jusification of Mission Need (DOE 1993), the Tri-Party Agreement (Ecology et al. 1996), and the TWRS EIS ROD (62 FR 8693) and are shown in Table 19.

\subsection{PHASE 2 MISSION MEASURES OF SUCCESS}

For the TWRS Phase 2 mission, Table 20 summarizes the key measures of success. These measures of success are based on the end states for the TWRS Phase 2 mission. 
Table 19. Tank Waste Remediation System Phase 2 Mission Goals and Objectives.

\begin{tabular}{|c|c|}
\hline Goal & Objective \\
\hline \multirow{3}{*}{$\begin{array}{l}\text { Resolve tank system safety issues. } \\
\text { Operate and maintain facilities to } \\
\text { provide continued safe and } \\
\text { environmentally sound storage. }\end{array}$} & Resolve tank system safety issuẹ. \\
\hline & Upgrade facilities as necessary until they can be closed. \\
\hline & $\begin{array}{l}\text { Reduce operating costs to acceptable levels necessary to safely manage the } \\
\text { tank waste. }\end{array}$ \\
\hline \multirow[t]{3}{*}{$\begin{array}{l}\text { Mitigate the consequences of a tank leak } \\
\text { to the environment. }\end{array}$} & 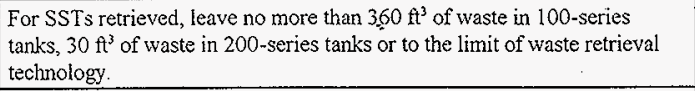 \\
\hline & $\begin{array}{l}\text { Remove a minimum of } 99 \% \text { of waste from DSTs or to the limit of } \\
\text { technology. }\end{array}$ \\
\hline & $\begin{array}{l}\text { Reduce operating costs to acceptable levels necessary to safely retrieve the } \\
\text { tank waste. }\end{array}$ \\
\hline $\begin{array}{l}\text { Reduce the impact on the repository and } \\
\text { on Hanford Site land use. }\end{array}$ & Pretreat the tank waste. \\
\hline \multirow{4}{*}{$\begin{array}{l}\text { Immobilize and dispose of any } \\
\text { remaining mixed or ILAW. }\end{array}$} & Achieve acceptable levels of safety and environmental risk. \\
\hline & Achieve an acceptable volume of LAW reduction. \\
\hline & Provide permanent storage and disposal of the LAW. \\
\hline & $\begin{array}{l}\text { Reduce operating costs to acceptable levels necessary to safely immobilize } \\
\text { the ILAW. }\end{array}$ \\
\hline \multirow{6}{*}{$\begin{array}{l}\text { Immobilize IHLW and TRU } \\
\text { constituents of waste. }\end{array}$} & Achieve acceptable levels of safety and environmental risk. \\
\hline & Achieve an acceptable volume of $H Z W W$ reduction. \\
\hline & Enable permanent disposal. \\
\hline & Provide interim storage of $\mathrm{HLW}$. \\
\hline & Dispose of cesium and strontium. \\
\hline & $\begin{array}{l}\text { Reduce operating costs to acceptable levels necessary to safely immobilize } \\
\text { the IHLW and TRU waste. }\end{array}$ \\
\hline \multirow[t]{3}{*}{$\begin{array}{l}\text { Close the inactive underground storage } \\
\text { tanks. }\end{array}$} & $\begin{array}{l}\text { Prepare SST farms and associated miscellaneous underground storage } \\
\text { tanks for closure. }\end{array}$ \\
\hline & $\begin{array}{l}\text { Prepare DST farms and associated miscellaneous underground storage } \\
\text { tanks for closure. }\end{array}$ \\
\hline & Achieve acceptable levels of safety and environmental risk. \\
\hline \multirow{4}{*}{$\begin{array}{l}\text { Decontaminate, decommission, and } \\
\text { close most TWRS facilities (a limited } \\
\text { number of older facilities will be } \\
\text { transferred to the Environmental } \\
\text { Restoration Project for action). }\end{array}$} & Reduce the number of active facilities. \\
\hline & Achieve acceptable levels of operational liabilities. \\
\hline & $\begin{array}{l}\text { Achieve an acceptable generation of secondary waste and effluent to reduce } \\
\text { environmental impact and cost. }\end{array}$ \\
\hline & $\begin{array}{l}\text { Reduce operating costs to acceptable levels necessary to decontaminate, } \\
\text { decommission, and close TWRS facilities. }\end{array}$ \\
\hline $\begin{array}{l}\text { DST }=\text { double-sliell tank. } \\
\text { HLW }=\text { high-level wastc. } \\
\text { LAW }=\text { low-activity waste. }\end{array}$ & $\begin{array}{l}\text { SST }=\text { singlc-shell tank } \\
\text { TRU }=\text { iransurnic. } \\
\text { TWRS }=\text { Tank Waste Remediation System. }\end{array}$ \\
\hline
\end{tabular}


Table 20. Measures of Success - Tank Waste Remediation System Phase 2 End States.

\begin{tabular}{|c|c|}
\hline TWRS acceptable end state & Measure of success \\
\hline Closed ILAW sites & ILAW will be disposed onsite by 2028 . \\
\hline Closed DSTs & 28 DSTs will be closed by 2034. \\
\hline Closed SSTs & 149 SSTs will be closed by 2024 \\
\hline Closed MUSTs & $\begin{array}{l}48 \text { MUSTs were assigned to TWRS at the beginning of FY } 1997 \text {. The } \\
\text { MUSTs declared inactive will be closed by } 2024 \text {. The balance of the } \\
\text { MUSTs will be closed by } 2034 \text {. }\end{array}$ \\
\hline IHIW & HLW immobilized and in interim storage by 2028 . \\
\hline Cesium and strontium capsules & $\begin{array}{l}\text { Cesium and strontium capsules dispositioned and contents glassified by } \\
2028 \text {. }\end{array}$ \\
\hline Risk reduction & Significantly reduce risk to the worker, the public, and the environment. \\
\hline Mortgage reduction & Significantly reduce or eliminate mortgage costs. \\
\hline Land use & $\begin{array}{l}\text { Significantly increase the amount of land and other resources for other } \\
\text { private and government uses. }\end{array}$ \\
\hline Gaseous effluents & $\begin{array}{l}\text { Achieve an acceptable volume of untreated gaseous effluents released } \\
\text { to the environment. }\end{array}$ \\
\hline Liquid effluents & Achieve an acceptable volume of released liquid effluents. \\
\hline Solid waste & Achieve an acceptable volume of released, noncompliant solid wastes. \\
\hline $\begin{array}{l}\text { Beneficial materials, reusable materials, } \\
\text { and technology transfer }\end{array}$ & $\begin{array}{l}\text { Maximum number and/or volume of items transferred to the Hanford } \\
\text { Site in support of the Site mission, or transferred external to the Site in } \\
\text { support of other DOE missions by } 2033 \text {. }\end{array}$ \\
\hline Ancillary tank farm facilities & Ancillary tank farm equipment will be closed by 2034 . \\
\hline $\begin{aligned} \text { DOE } & =\text { U.S. Department of Energy. } \\
\text { DST } & =\text { double-shell tank. } \\
F Y & =\text { fiscal year. } \\
\text { HLW } & =\text { high-level waste. } \\
\text { HAW } & =\text { immobilized higl-activity waste. }\end{aligned}$ & $\begin{aligned} \text { ILAW } & =\text { immobilized lowv-activity wastc. } \\
\text { MUST } & =\text { miscellaneous underground storage tank. } \\
\text { SST } & =\text { single-shlell tank. } \\
\text { TWRS } & =\text { Tank Waste Remediation Systen. }\end{aligned}$ \\
\hline
\end{tabular}

\subsection{PHASE 2 MISSTON SUMMARY ANALYSIS}

This section summarizes the requirements analysis that has been performed, identifies the major facilities that must be constructed, and makes conclusions and recommendations for the TWRS Project.

\subsection{PHASE 2 MISSION ANALYSIS INTRODUCTION}

Approximately 55,000 MT of sodium will remain to be retrieved (from SSTs and DSTs) and immobilized in the full-scale plants operated in Phase 2. The Phase 2 functional requirements 
were derived from the Tri-Party Agreement (Ecology et al. 1996) milestones, the TWRS EIS (DOE and Ecology 1996), preliminary DOE planning assumptions, and anticipated tank waste status at the end of Phase 1B. Major milestones from the Tri-Party Agreement are listed in Table 21. These requirements were used to form the initial conditions for optimizing feed delivery rates, private contractor processing rates, and tank farm operations activities.

\subsection{PHASE 2 LOW-ACTIVITY WASTE AND HIGH-LEVEL WASTE PROCESSING}

During the execution of the Phase 2 mission, private contractors will build additional LAW and HLW treatment capability. This increased capacity will be required because of the anticipated processing rates that are needed to meet retrieval and closure milestones. Figure 11 shows the overall retrieval rates for Phase 1 and Phase 2 . This additional capability could come from expansion of existing Phase 1 facilities or construction of additional facilities.

\subsubsection{Phase 2 Feed Delivery Rate Requirements}

The Tri-Party Agreement (Ecology et al. 1996) milestones and the TWRS EIS (DOE and Ecology 1996) target retrieval of the wastes from all SSTs by late 2018 and completion of waste processing for LAW streams by 2024 and high-activity waste streams by 2028 . Estimated annual SST retrieval sequencing and tank retrieval schedules were used to determine Phase 1 implementation of DST space limitations, and logistics of the tank farm transfer systems (existing and new construction). The determinations are documented in the Tank Waste Remediation System Operation and Utilization Plan (Kirkbride et al. 1997) and indicate that the earliest that SST retrieval can be completed will be late in 2020 . However, the associated waste immobilization will be completed before the M-60 and M-51 milestone dates (Ecology et al. 1996).

\subsubsection{Feed Delivery Analysis}

Figure 11 illustrates the Phase $1 \mathrm{~B}$ and 2 processing rates. The Phase 1 program planning basis assumes that each private contractor will process $2 \mathrm{MT}$ of sodium per day. At these rates, the minimum order quantities would be processed by 2005 and the Phase $1 \mathrm{~B}$ maximum order quantity would be completed by approximately 2009. Assuming the DOE will extend the operation of the Phase 1 facilities concurrent with Phase 1 immobilization, SST wastes would be retrieved to DSTs for staging in anticipation of Phase 2 . This volume includes approximately $10,000 \mathrm{MT}$ of sodium which will be added during sludge washing. 
Table 21. Hanford Federal Facility Agreement and Consent Order Milestones. (2 sheets)

\begin{tabular}{|l|l|l|}
\hline Milestone* number & \multicolumn{1}{|c|}{ Milestone title } & \multicolumn{1}{|c|}{ Due date } \\
\hline M-45-02 & Annual Update SST Retrieval Sequence Document & Annually \\
\hline M-60-12 & $\begin{array}{l}\text { Start Hot Operations of 2 COCO Phase 1 LAW pretreatment } \\
\text { and Immobilization Facilities }\end{array}$ & December 2002 \\
\hline M-45-03-T=01 & Full-Scale Demonstration of SST Retrieval Technology & September 2003 \\
\hline M-45-05 & Complete SST Retrieval & September 2018 \\
\hline M-45-00 & Complete Closure of All SSTs & September 2024 \\
\hline M-60-00. & Complete LAW Processing & December 2024 \\
\hline M-51-00 & Complete FILW Processing & December 2028 \\
\hline
\end{tabular}

*Ecology, EPA, and DOE, 1996. Hanford Federal Facility -Agreement and Consent Order, 2 vols. Washington State Department of Ecology, U.S. Environmental Protection Agency, and U.S. Department of Enurgy. Olympia, Washington. $\mathrm{COCO}=$ contractor-owned contractor-operated. $\quad$ L.AW = low-activity wastc HLW = hight-level waste. $\quad . . \quad$ SST $=$ single-shcll tank.

After Phase 1B feed is processed, the waste processing plan (base case) will enter into a post-Phase 1 evaluation phase. During the evaluation phase, construction of additional capacity production facilities will be completed. Given DST space limitations, this base case plan would result in a 3-year period in which only SSTs with a small inventory could be retrieved. This would maintain the number rate of retrievals required by the Tri-Party Agreement (Ecology et al. 1996), but would not significantly reduce the volume of waste stored in SSTs. At the end of Phase $1 \mathrm{~B}$, approximately 132.5 million liters ( $32 \mathrm{Mgal}$ of waste $[\sim 38,000 \mathrm{MT}$ of sodium]) would remain in the SSTs (before washing or caustic addition).

The base case Phase 2 processing rate assumptions require a scale-up of LAW processing capability to $26 \mathrm{MT}$ of sodium (172 MT of glass) per day. This could be accomplished by expanding each of the two Phase $1 \mathrm{~B}$ LAW processing plants to a capacity of $13 \mathrm{MT}$ of sodium (86 MT of glass) per day. This type of expansion carries a large risk in that immobilization plants of this capacity have yet to be built (see Section 13.3).

\subsection{WASTE REMOVAL OPTMMIZATION RECOMMENDATIONS}

Several improvements should be evaluated to accelerate the removal of waste from the SSTs, reduce the complexity and scale of the retrieval mission, and reduce the scale-up required to meet the full-scale production mission requirements. These recommendations will require deviation from the baseline case. 
Figure 11. Phase 2 Low-Activity Waste and High-Level Waste Feed Staging.

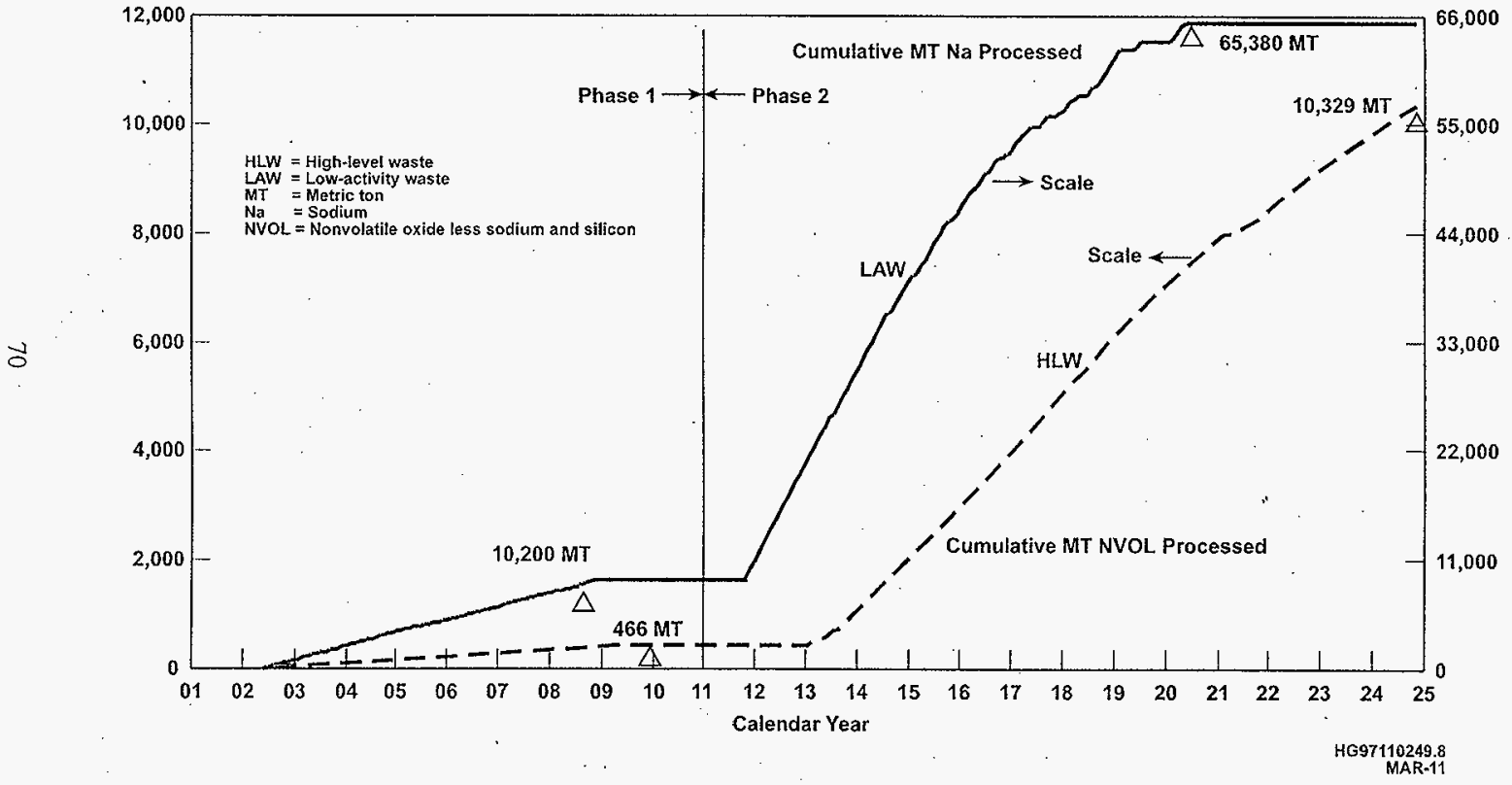


An early increase in the feed rate for the Phase 1 facilities (after minimum order quantities have been processed), coupled with extension of the operation of the Phase 1 facilities, could have a significant positive effect. This extension would accelerate the rate of waste retrieval from SSTs, dramatically reduce the scale-up required, and improve the overall feasibility of completing the entire mission.

A simplified analysis was used to develop recommendations that could be used to optimize Phase 2. This analysis will need to be refined to include tank sequencing, space limitations, and processing considerations in order to confirm the quality of the improvements that would be achieved as a result of implementation of these recommendations.

This analysis assumes that there would be two Phase 1 LAW immobilization facilities. Further, it is assumed that in order to process the waste to meet commitments, it will be necessary to scale up each of the LAW plants' processing capability from 2 MT of sodium to 13 MT of sodium (100 MT of glass). To match this increased processing capacity, retrieval rates would also have to be scaled up significantly. Based on sluicing experience, each sluicing unit could reliably sluice approximately 7,200 L ( 1,900 gal [2.3 MT of sodium]) of wastes (approximately 8 molar after retrieval and dilution) from a tank per day. During the sluicing process, total volumes will be increased by a factor of approximately 3.3 for every liter of waste sluiced. Thus, the total volume to be treated will increase to approximately 435.3 million liters (115 Mgal) of waste as a result of the retrieval process. The SSTs currently contain approximately $42,000 \mathrm{MT}$ of sodium $(38,000 \mathrm{MT}$ after Phase 1$)$.

Therefore, to match the Phase 2 processing rates of $26 \mathrm{MT}$ of sodium (172 MT of glass) per day (during the first 3 years), approximately $81,000 \mathrm{~L}(21,500 \mathrm{gal})$ of waste will have to be sluiced which would require 11 tanks to be sluiced simultaneously. Table 22 presents the results of several studies comparing the required number of retrieval systems, SST retrieval completion dates, and the maximum number of retrieval systems.

Table 22. Number of Concurrent Retrieval Systems.

\begin{tabular}{|c|c|c|}
\hline Information source & SST retrieval completion & $\begin{array}{c}\text { Peak SST retrieval systems in } \\
\text { operation }\end{array}$ \\
\hline 1996 SST feed staging case study & 2020 & 16 \\
\hline $\begin{array}{l}1997 \text { Tank Waste Remediation } \\
\text { System Operation and Utilization } \\
\text { Plan* baseline case }\end{array}$ & 2020 & 10 \\
\hline $\begin{array}{l}\text { Assumed average retrieval rate } \\
\text { calculation }\end{array}$ & 2020 & 11 \\
\hline
\end{tabular}

*Kirkbride, R.A., G. K. Allen, P. J. Certa, A. F. Manust. R. M. Ornte, L. W. Shelton, E. J. Slaathaug, R. S. Wittman (NHC), G. T. MacLear, and D. L. Penwell (SESC), 1997, Tank Waste Remediation System Operation and Utilization Plan. HNF-SD-WM-SP-012, Rev. 0, Vol. I and II, prepared by Numatec Hanford Corporation for Fluor Daniel Hanford, Inc.. Richland, Washington. $S S T=$ single-shell tank . 
Figure 12 shows the result of an example of a case with improved performance over the current planning base line. In this case, the Phase 1 private contractors would be allowed to ramp up to their maximum production capacity as soon as the minimum feed quantities of Envelopes $\mathrm{A}$, $\mathrm{B}$, and $\mathrm{C}$ are demonstrated. The operation of these expanded Phase 1 facilities would be extended to 2011, followed by expansion into full-scale production capacity facilities. For the accelerated start, during the latter part of FY 2006 and continuing to approximately FY 2009, each ILAW plant would increase production to approximately $3 \mathrm{MT}$ of sodium $(220 \mathrm{MT}$ of glass). Then during FY 2009, each ILAW plant would.increase production to $6 \mathrm{MT}$ of sodium (40 MT of glass) for the balance of Phase 2 processing. The improved case would approximately double the waste processed by 2011 . Table 23 shows a comparison of the existing base case to this improved example.

While detailed modeling and analysis, along with detailed design and capacity information from the Phase 1 private contractors, will be necessary to optimize this scenario, there are positive indications that a much more feasible scenario for the Phase 2 production plan can be developed and should be pursued.

\subsection{MELTER CAPACITY SCALE-UP COMPARISON WITH COMMERCIAL INDUSTRY}

The baseline Phase 2 processing rates require a major increase in immobilization plant capacity. This scale-up may not be achievable based on reasonable extensions of exiting technology and recent nuclear immobilization plant experiences.

The largest remote radioactive melter in the DOE complex is $2.4 \mathrm{MT}$ per day of glass product at the Defense Waste Processing Facility at Savannah River. Joule-heated or cold-wall induction melters used at United States and European facilities can be designed for larger capacities ( 5 to $10 \mathrm{MT}$ per day), but are not likely to achieve the rates required for LAW processing (approximately $86 \mathrm{MT}$ per day) in Phase 2. Commercial glass plant capacities are much higher, but are not able to be directly applied because of differences in melter design, feed consistency, and remote operation (due to radioactivity) considerations. Multiple melter lines with the production-scale facilities or multiple facilities will be required to meet the current Phase 2 production rate assumptions.

In general, scale-up of remotely operated and maintained radioactive melters to the capacities required to support the current Phase 2 planning assumptions appears unlikely without a technology breakthrough. Scale-up of the radioactive glass melters will likely be limited to around $10 \mathrm{MT}$ per day per melter line: Two LAW plants with two melter lines each could each produce about $40 \mathrm{MT}$ glass per day, which appears to be a reasonable planning assumption at this time. 
Figure 12. Low-Activity Waste Processing - Production Improvements.

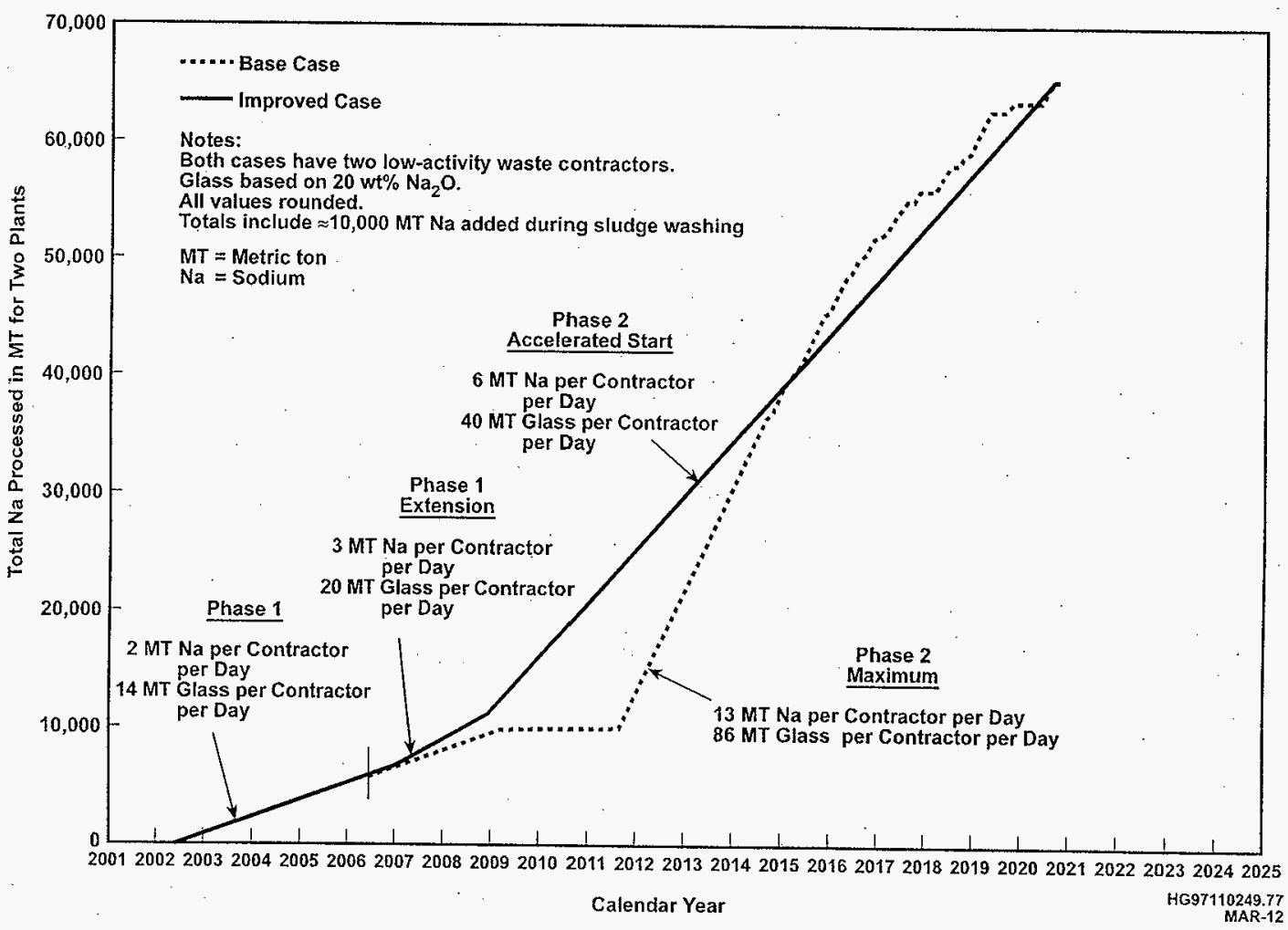


Table 23. Comparison of Tank Waste Remediation System Planning Baseline and Example Mission Improvements Case.

\begin{tabular}{|l|c|c|}
\hline \multicolumn{1}{|c|}{ Affected area } & TWRS planning baseline & Example case mission improvements \\
\hline SST retrieval completion & 2020 & 2020 \\
\hline Maximum retrieval systems in operation & 11 & 5 \\
\hline $\begin{array}{l}\text { Maximum Phase 2 melter rate (MT glass/day } \\
\text { for each private contractor) }\end{array}$ & $86 \mathrm{MT} /$ day & $40 \mathrm{MT} /$ day \\
\hline Waste processed by 2011 (MT sodium) & $10,000 \mathrm{MT}$ & $21,000 \mathrm{MT}$ \\
\hline
\end{tabular}

NOTE 1: Average rate over Phase 2 .is approximately $60 \mathrm{MT}$ per contractor per day, but $100 \mathrm{MT}$ per contractor per day will be required early in Phase 2.

$M T=$ metric ton

SST $=$ singlc-shell tank.

TWRS $=$ Tank Waste Remediation System

\subsection{PHASE 2 ADDITIONAL CONSIDERATIONS}

The physical layout of the tank farm systems, assumptions about the amount of new construction required for retrieval and transfer facilities, and the anticipated complexity of field sluicing operations lead one to the conclusion that it would be extremely difficult to sluice more than one tank simultaneously in one tank farm quadrant. One exception is the T Farm complex ( $T$, TX, TY) which contains 40 tanks and is farther from the existing infrastructure.

The analysis indicates that new retrieval annexes will need to be built, along with additional transfer lines. With the new annexes, two tanks could be sustained in operation in the T Farm complex. The retrieval and transfer infrastructure would be distributed in the four major quadrants that make up the tank farm system (northeast, southeast, northwest, and southwest [see Figure 13]). Assuming that two tanks are being sluiced simultaneously in the T Farm complex (northwest quadrant), it is likely that only one tank in each remaining quadrant could be operated. during the same time frame without creating extensive operations resource loading and command and control concerns. Therefore, it is recommended that the maximum Phase 2 tank retrieval rates be limited to a maximum of five tanks simultaneously (two tanks in TX, one tank in each remaining quadrant).

\subsection{TANK CLOSURE PROCESSING}

The approach for closing the tank farms, following completion of the waste retrieval operations, has not been defined. The TWRS EIS ROD stipulates that decisions on tank farm closure will be reached through a NEPA process, once sufficient information is available to initiate that process. 
Figure 13. Retrieval and Transfer System Infrastructure.

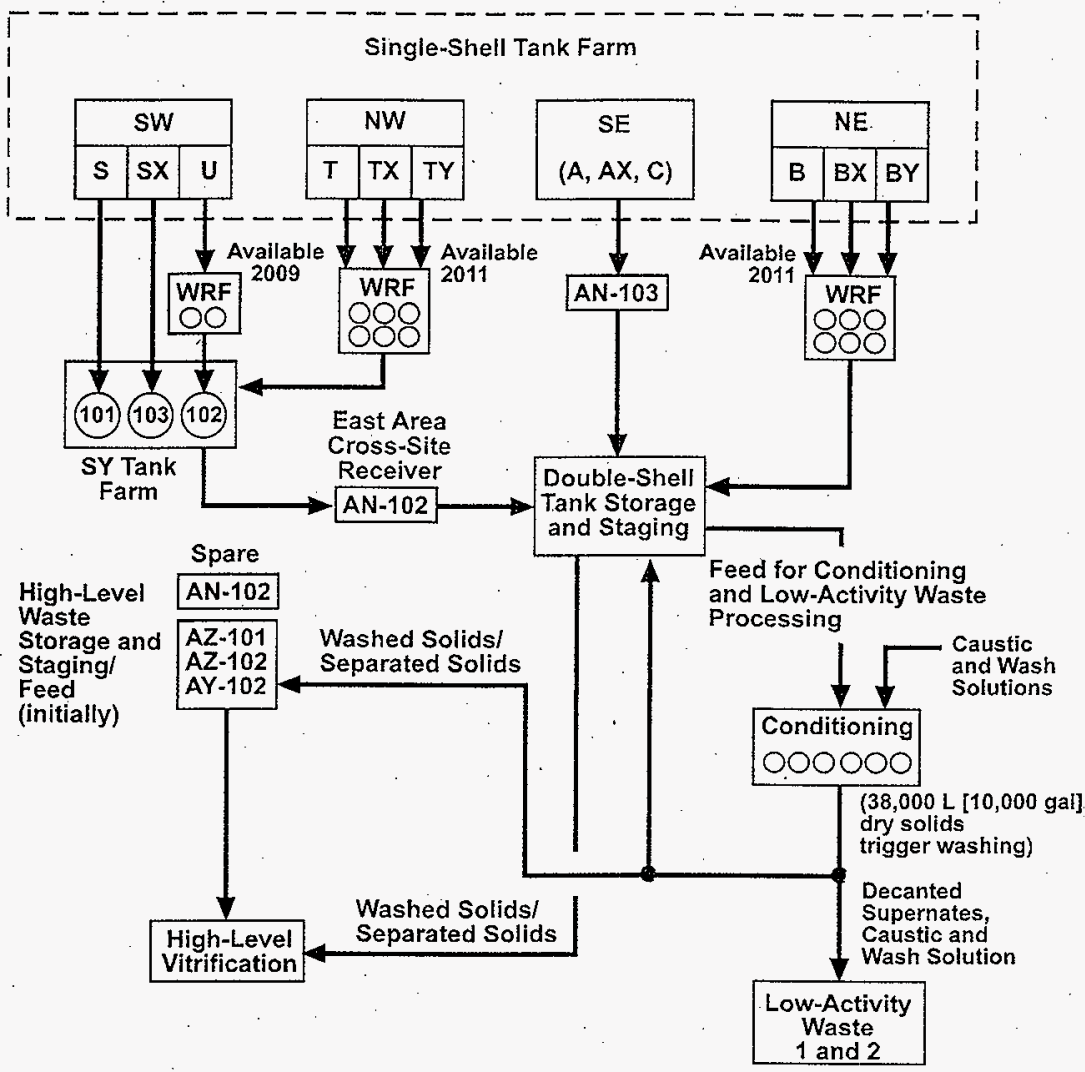

WRF $=$ Waste Retrieval Facility

HG97110249.75

MAR-13 
The current TWRS Integrated Baseline assumes that SSTs and DSTs will be closed with small quantities of residual waste that cannot practicably be retrieved. Under this closure assumption, an engineered fill material would be placed in tanks for long-term structural stability and a surface barrier placed over the entire tank farm, or over multiple adjoining tank farms, to limit infiltration of water. In this case, tank fill likely would be placed in each tank shortly following completion of retrieval operations for that tank. However, surface barriers would not be placed until the entire tank farm or aggregate of adjoining tank farms have completed tank waste retrieval operations and $\mathrm{D} \& \mathrm{D}$ activities.

If the NEPA process for tank farm closure results in a decision to remove tanks, or to excavate contaminated soil, tank farm closure operations likely would be unable to commence until completion of retrieval operations for entire tank farms or possibly for the aggregate of adjoining tank farms.

Schedules for tank farm closure, or partial closure, will be developed as part of the planned NEPA process to translate closure alternatives for the TWRS underground waste storage tanks.

\subsection{TANK WASTE REMEDLATION SYSTEM FACILITIES REQUIRED FOR THE PHASE 2 MISSION}

\subsubsection{Phase 2 Mission - Required Facilities}

The TWRS facilities required for Phase 2 of the mission and their current life-cycle phase are briefly described as follows.

- The SST System will be used primarily in Phase 2 mission activities. The SST System is currently in the latter stages of its O\&M phase. Retrieval activities will carry parts of the SST System back into the planning, preconceptual, conceptual, and project execution phases.

- The DST System will be used in Phase 2 of the mission. The DST System currently is in the O\&M phase of its life cycle. Retrieval activities will carry parts - of the DST System back into the planning, preconceptual, conceptual, and project execution phases.

- The LAW Treatment Facility Phase 2, will be used in the TWRS Phase 2 mission. This facility provides additional capacity to the Phase 1 LAW Plant either by expansion or addition and is in the planning phase of its life cycle.

- The HLW Treatment Facility, Phase 2, will be used in the TWRS Phase 2 mission. This facility provides additional capacity to the Phase 1 HLW Plant either by expansion or addition and is in the planning phase of its life cycle. 
HNF-SD-WM-MAR-008 Rev 3

- The CSB: TWRS CSB modules will be in the O\&M phase and will be used during the TWRS Phase 2 mission.

- The IHLW storage modules. Phase 2, will be used during the TWRS Phase 2 mission. This facility provides additional capacity to the CSB either by expansion or addition and is in the planning phase of its life cycle.

- $\quad$ The ILAW Disposal Facility used in Phase 1 will be in the O\&M phase and will continue to be used in Phase 2.

Figure 10 illustrates the life cycles for the TWRS facilities in both phases of the mission.

\subsubsection{Phase 2 Mission Facilities' Functional Requirements}

Major functions have been assigned to each TWRS major facility required for the Phase 2 mission. These are currently captured in the TWRS Technical Baseline contained in the HSTD. Functions for the SST System, the DST System, and the TWRS CSB storage modules are listed in Table 17. The functional requirements that are associated with the additional required major TWRS facilities are listed in Table 24. These functional requirements also will be used in the major TWRS facility specifications documents.

\subsection{PHASE 2 MISSION RECOMMENDATIONS}

The mission analysis shows that several recommendations should be considered to accelerate the removal of waste from the SSTs. These recommendations are outlined in the following paragraphs.

- Consider relaxation of the feed envelopes as soon as the minimum demonstration order quantities of Envelopes A, B, and $\mathrm{C}$ are completed. This would allow TWRS to deliver waste feed.at rates greater than $2 \mathrm{MT}$ of sodium per contractor per day, and should allow the private contractors to process waste faster and more efficiently. The demonstration requirements of the privatization strategy would be met, while faster processing of waste during Phase $1 \mathrm{~B}$ would free up space and allow more SST retrievals to occur prior to completion of construction of the full-scale production facilities in Phase 2.

- $\quad$ Phase 2 feasibility could be further increased by accelerating the Phase 2 start date to coincide with the completion of Phase $1 \mathrm{~B}$ maximum order feed processing $(\sim 2009)$. This would accelerate the start of Phase 2 processing by nearly 3 years and would also decrease the scale-up required to go from demonstration production rates to full-scale production rates while still maintaining the planned retrieval end date of 2020 . 
Table 24. Phase 2 Tank Waste Remediation System Major Facilities Functional Requirements.

LAW Treatment Facility, Phase 2

The LAW Treatment Facility, Phase 2 will receive and treat the waste delivered by the DST System and immobilize the low-activity fraction of the waste delivered. Treatment includes separation of the LAW fraction from the HLW fraction. The LAW Treatment Facility, Phase 2 will transfer the remaining HLW fraction to the HLW Treatment Facility, Phase 2. The LAW Treatment Facility, Phase 2 will package and transfer the ILAW product to the ILAW Disposal Facility.

The LAW Treatment Facility, Phase 2 will perform the activities necessary to place the system components into a safe, stable, and environmentally sound condition pending final disposition.

The LAW Treatment Facility, Phase 2 will be maintained in a safe and compliant mode until turnover to the D\&D phase.

At the completion of the operational mission, the LAW Treatment Facility, Phase 2 will provide for decontamination of its system components and soils.

FILW Treatment Facility, Phase 2

The HIW Treatment Facility, Phase 2 will receive, treat/disposition, and immobilize waste delivered by: (1) the Phase 2 LAW Treatment Facility; (2) the Waste Encapsulation and Storage Facility (cesium and strontium capsules); and (3) the TWRS CSB modules, Phase 1 (cesium canisters). The HILW Treatment Facility, Phase 2 will seal the IHLW in primary canisters, decontaminate the container surface, and test the integrity of the sealed canisters. The HLW Treatment Facility, Phase 2 will load the HHLW onto the transport mechanism and transfer the IHLW to the IHLW Storage modules, Phase 2.

The HLW Treatment Faciliry, Phase 2 will perform the activities necessary to place the system components into a safe, stable, and environmentally sound condition pending final disposition.

The FLW Treatment Facility, Phase 2 will be maintained in a safe and compliant mode until tumover to the D\&D phase.

At the completion of the operational mission, the HLW Treatment Facility, Phase 2 will provide for decontamination of its system components and soils.

II-IW Storage modules, Phase 2

The IHLW Storage modules, Phase 2 will receive, prepare, and place canisters of DEI $W$ from the HLW Treatment Facility, Phase 2. The IHLW Storage modules, Phase 2 will monitor the IHLW canister storage locations for storage . containment integrity.

The IHLW Storage modules, Phase 2 will prepare and load out stored IHLW to the geologic repository. The IHLW Storage modules, Phase 2 will prepare the IHLW stored within the IHLW Storage modules, Phase 2 for transport by verifying the IF-JW is properly packed for shipment and certified for offsite transportation.

The IHLW storage modules, Phase 2 will perform the activities necessary to place the system components into a safe, stable, and environmentally sound condition pending final disposition.

The IHLW storage modules, Phase 2 will be maintained in a safe and compliant mode until turnover to the D\&D phase.

At the completion of the operational mission, the IHLW storage modules, Phase 2 will provide for decontamination of its system components and soils.

$\mathrm{CSB}=$ Canister Storage Building.

$D \& D=$ decontamination and decommissioning.

DST $=$ doubie-shell tank.

HLW = high-level waste.
II-IL $\mathrm{W}=$ inmobilized high-level waste.

ILAW = inmobilized low-activity waste.

LAW $=$ low-activity waste.

TWRS = Tank W Waste Remediation System. 
-. Size the Phase 2 full-scale production facilities (or capacity upgrades to the Phase 1 facilities) to process the remaining SST waste at a constant rate, starting in 2009 and finishing as early as practical. Current analysis indicates that processing could be completed by 2024 , with SST retrieval completed by 2020 . This strategy is discussed in Section 10.2.4. The net effect, if implemented, would be to reduce the simultaneous tank retrieval systems to a reasonable number (as low as five), and to reduce the scale-up required from $100 \mathrm{MT}$ of glass processed per day per facility to around $40 \mathrm{MT}$ of glass processed per day per facility. This would have the effect of doubling the waste processed by 2011.

\subsection{REFERENCES}

\section{Code of Federal Regulations}

10 CFR 60, 1992, "Disposal of High-Level Radioactive Wastes in Geologic Repositories," Code of Federal Regulations.

10 CFR 71, 1992, "Packaging and Transportation of Radioactive Material," Code of Federal Regulations.

10 CFR 835, 1993, "Occupational Radiation Protection," Code of Federal Regulations.

40 CFR 61, 1991, "National Emission Standards for Hazardous Air Pollutants," Code of Federal Regulations.

40 CFR 191, 1991, "Environmental Radiation Protection Standards for Management and Disposal of Spent Nuclear Fuel, High-Level and Transuranic Radioactive Wastes," Code of Federal Regulations.

40 CFR 241, 1992, "Guidelines for the Land Disposal of Solid Wastes," Code of Federal Regulations.

40 CFR 261, 1996, "Identification and Listing of Hazardous Waste," Code of Federal Regulations.

40 CFR 264, 1991, "Standards for Owners and Operators of Hazardous Waste Treatment, Storage, and Disposal Facilities," Code of Federal Regulations.

40 CFR 268, 1991, "Land Disposal Restrictions," Code of Federal Regulations. 


\section{Federal Register}

58 FR 66398, 1993, "Environmental Protection Agency," Federal Register, Vol. 58, pp. 66398-66416 (December 20).

62 FR 8693, 1997, "Record of Decision for the Tank Waste Remediation System, Hanford Site, Richland, WA" Federal Register, Vol. 62, pp. 8693-8704 (February 26).

Acts

National Environmental Policy Act of 1969, as amended, 42 USC 4231 et seq.

Resource Conservation and Recovery Act of 1976, as amended, 42 USC 6901 et seq.

\section{DOE Orders}

DOE Order 4330.4B, Maintenance Management Program, U.S. Department of Energy, Washington, D.C., 1994.

DOE Order 5820.2A, Radioactive Waste Management, U.S. Department of Energy, Washington, D.C., 1988.

\section{Good Practice Guides}

GPG-FM-004, Reliability, Maintainability, Availability Planning, Life Cycle Asset Management, Good Practice Guide, U.S. Department of Energy, Washington, D.C.

GPG-FM-010, Project Execution and Engineering Management Planning, Life Cycle Asset Management, Good Practice Guide, U.S. Department of Energy, Washington, D.C.

GPG-FM-031, Maintenaince, Life Cycle Asset Management, Good Practice Guide, U.S. Department of Energy, Washington, D.C.

\section{Washington Administrative Code}

WAC 173-303, "Dangerous Waste Regulations," Washington Administrative Code, as amended.

WAC 173-400, "Regulations for Air Pollution Sources," Washington Administrative Code, as amended.

WAC 173-401, "Operating Permit Regulation," Washington Administrative Code, as amended. 
HNF-SD-WM-MAR-008 Rev 3

WAC 173-460, "Controls for New Sources of Toxic Air Pollutants," Washington Administrative Code, as amended.

WAC 246-247, "Radiation Protection-Air Emissions," Washington Administrative Code, as amended.

\section{Databases}

EMACS, n.d., Enabling Assumptions Management and Control System Database, maintained by Lockheed Martin Hanford Corporation for Fluor Daniel Hanford, Inc., Richland, Washington.

HSTD, n.d., Hanford Site Technical Database, maintained by Lockheed Martin Hanford Corporation for Fluor Daniel Fanford, Inc., Richland, Washington.

WIDS, n.d., Hanford Site Waste Information Data System Database, maintained by Bechtel Hanford, Inc., for the U.S. Department of Energy, Richland Operations Office, Richland, Washington.

\section{Documents}

Baldwin, J. H., T. J. McLaughlin, R. D. Potter, and R. L. Treat, 1998, Tank Waste Remediation System Retrieval and Disposal Mission Key Enabling Assumptions, HNF-1945, Rev. 1, prepared by Lockheed Martin Hanford Corporation for Fluor Daniel Hanford, Inc., Richland, Washington.

Boothe, G. F., 1995, Remediation and Cleanout Levels for Hanford Site Single-Shell Tanks, WHC-SD-WM-TI-711, Rev. 0, Westinghouse Hanford Company, Richland, Washington.

Brevick, C. H., 1997, 200 Area Platean Inactive Miscellaneous Underground Storage Tanks Locations, HNF-1566, Rev. 0, Fluor Daniel Northwest Services, Richland, Washington.

Calmus, R. B., 1997, Tank Waste Remediation System Retrieval and Disposal Mission Immobilized High-Level Waste Storage, HNF-1751, Rev. 0, Project Hanford Management Contractors, Fluor Daniel Hanford, Inc., Richland, Washington.

Claghorn, R. D., 1997, Decision Document for the Final Disposition of Cesium and Strontium Capsules, HNF-SD-WM-RPT-294, Rev. 0, prepared by Numatec Hanford Corporation for Fluor Daniel Hanford, Inc., Richland, Washington.

Dirks, L. L., and D. VonWinterfel, 1994, Public Values Related to Decisions in the Tank Waste Remediation System Program, PNL-10107, Pacific Northwest Laboratory, Richland, Washington. 
DOE, 1990, Interim Report of the DOE Type B Investigation Group. Cesium-137: A Systems Evaluation Encapsulation to Release Radiation Sterilizers, Inc., DOE/ORO-914, U.S. Department of Energy, Washington, D.C.

DOE, 1993, Justification of Mission Need, Hanford Site Tank Waste Remediation System to the Energy System Acquisition Advisory Board, U.S. Department of Energy, Washington, D.C.

DOE, 1996, Draft Hanford Remedial Action Environmental Impact Statement and Comprehensive Land Use Plan, DOE/EIS-0222D, U.S. Department of Energy, Washington, D.C.

DOE and Ecology, 1996, Tank Waste Remediation System, Hainford Site, Richland, Washington, Final Environmental Inpact Siatement, DOE/EIS-0189, U.S. Department of Energy and Washington State Department of Ecology, Washington, D.C.

DOE-OCRWM, 1993, Waste Acceptance System Requirements Document (WAS-RD), DOE/RW-0351P, Rev. O, U.S. Department of Energy, Office of Civilian Radioactive Waste Management, Washington, D.C.

Ecology and EPA, 1994, Hanford Facility RCRA Permit, WA7890008967, as modified, Washington State Department of Ecology and U.S. Environmental Protection Agency, Olympia, Washington.

Ecology, EPA, and DOE, 1996, Hanford Federal Facility Agreement and Consent Order, 2 vols., Washington State Department of Ecology, U.S. Environmental Protection Agency, and U.S. Department of Energy, Olympia, Washington.

FDH, 1996, Subcontract between Fluor Daniel Hanford, Inc., and Lockheed Martin Hanford Corporation Contract $8023276+-9-K 001$, Richland, Washington.

FDH, 1997, Tank Waste Remediation System Basis for Interim Operation, HNF-SD-WM-BIO-001, Rev. 0, Fluor Daniel Hanford, Inc., Richland, Washington.

Freeman, D. V., 1998, Tank Waste Remediation System Program Plan, HNF-1883, Rev. 1, prepared by Lockheed Martin Hanford Corporation for Fluor Daniel Hanford, Inc., Richland, Washington.

Goeta, T. G., D. M. Hammond, and J. P. Harris III, 1998, Tank. Waste Remediation System Retrieval Authorization Basis Amendment Task Plan, HNF-1722, prepared by Lockheed Martin Hanford Corporation for Fluor Daniel Hanford, Inc., Richland, Washington.

Hanlon, B. M., 1997, Waste Tank Summary Report for Month Ending July 31, 1997, HNF-EP-0182-112, prepared by Lockheed Martin Hanford Corporation for Fluor Daniel Hanford, Inc., Richland, Washington. 
HNF-SD-WM-MAR-008 Rev 3

Hedquist, K. A., 1997, Project Management Plan for WESF $\mathrm{Cs}^{I 27}$ and SY ${ }^{90}$ Capsule Storage, HNF-SD-WM-PMP-025, Rev. 0, B\&W Hanford Company, Richland, Washington.

Hesser, W. A., P. A. Baynes, P. M. Daling, T. F. Demmitt, R. D. Jensen, L. E. Johnson, L. D. Muhlestein, S. M. O'Toole, A. L. Pajunen, M. B. Triplett, J. L. Waite, and T. M. Wintczak, 1995, Development of a Risk-Based Approach to Hanford Site Cleantp, Vol. 1, PNL-10651, Pacific Northwest Laboratory, Richland, Washington.

HFSUWG, 1992, The Future for Hanford: Uses and Cleamup, a Final Report of the Hanford Future Site Uses Working Group, funded by the U.S. Department of Energy, U.S. Environmental Protection Agency, and Washington State Department of Ecology, Richland, Washington.

HTWTF, 1993, Final Report: Hanford Tank Waste Task Force, Hanford Tank Waste Task Force, funded by Washington State Department of Ecology, U.S. Department of Energy, and U.S. Environmental Protection Agency, Richland, Washington.

INPO 85-032, 1985, Preventive Maintenance, Good Practice MA-307, Rev. 1, Institute of Nuclear Power Operations, Atlanta, Georgia.

INPO 89-009, 1989, Plant Predictive Maintenance, Good Practice MA-316, Institute of Nuclear Power Operations, Atlanta, Georgia.

Kinzer, J. E., 1997, Contract Number DE-AC06-96RL13200 - Nuclear Regulatory Commission (NRC) Agreement of Classification of Hanford Tank Waiste (letter 9755522 to President, Fluor Daniel Hanford, Inc., June 23), U.S. Department of Energy, Richland Operations Office, Richland, Washington.

Kirkbride, R. A., G. K. Allen, P. J. Certa, A. F. Manuel, R. M. Orme, L. W. Shelton, E. J. Slaathaug, R. S. Wittman (NHC), G. T. MacLean, and D. L. Penwell (SESC), 1997, Tank Waste Remediation System Operation and Utilization Plan, HNF-SD-WM-SP-012, Rev. 0, Vol. I and II, prepared by Numatec Hanford Corporation for Fluor Daniel Hanford, Inc., Richland, Washington.

Kupfer, M. J., A. L. Boldt, B. A. Figley, K. M. Hodgson, L. W. Shelton, and R. A. Watrous (LMHC), S. L. Lambert, and D. E. Place (SESC), R. M. Orme (NHC), G. L. Borsheim (Borsheim Associates), N. G. Colton (PNNL), M. D. LeClair (SAIC), R. T. Winward (Meier Associates), and W. W: Schulz (W²S Corporation), 1997, Standard Inventories of Chemicals and Radionuclides in Hanford Site Tank Wastes, HNF-SD-WM-TI-740, Rev. 1, prepared by Lockheed Martin Hanford Corporation for Fluor Daniel Hanford, Inc., Richland, Washington.

Lenseigne, D. L., 1997, Tank Waste Remediation System Fiscal Year 1998 Multi-Year Work Plan WBS 1.1, HNF-SP-1230, Rev. 0, prepared by Lockheed Martin Hanford Corporation for Fluor Daniel Hanford, Inc., Richland, Washington. 
LMHC, 1997, Tank Waste Remediation System Administration, HNF-IP-0842, Fluor Daniel Hanford, Inc., Richland, Washington.

McDonald, F. N., 1994, Acceptance of Feed Streams for Treatment at the LERF/ETF Complex, WHC-SD-ETF-WAC-001, Rev. 0, Westinghouse Hanford Company, Richland, Washington.

Mickle, G. D., 1995, Tank Farm Health and Safety Plan, WHC-SD-WM-HSP-002, Rev. 2, Westinghouse Hanford Company; Richland, Washington.

Peck, L. G., 1998, Tank Waste Remediation System Systems Engineering Management Plan, HNF-SD-WM-SEMP-002, Rev. 1, prepared by Lockheed Martin Hanford Corporation for Fluor Daniel Hanford, Inc., Richland, Washington.

Popielarczyk, R. S., 1996, TWRS Safety Management Plan, WHC-SD-WM-PLN-114, Rev. 1, Westinghouse Hanford Company, Richland, Washington.

Potter, R. D., 1998, Tank Waste Remediation System Retrieval and Disposal Mission Waste Feed Delivery Plan, HNF-1881, Rev. 0, prepared by Lockheed Martin Hanford Corporation for Fluor Daniel Hanford, Inc., Richland, Washington.

Raven, R. P., 1998, Tank Waste Remediation System Environmental Program Plan, FNF-1773, Rev. 0, prepared by Lockheed Martin Hanford Corporation for Fluor Daniel Hanford, Inc., Richland, Washington.

Rifaey, S. H., 1998, Tank Waste Remediation System Engineering Plan, HNF-1947, Rev. 0, prepared by Lockheed Martin Corporation for Fluor Daniel Hanford, Inc., Richland, Washington.

RL, 1994, FY 1995 Hanford Mission Plan Volume 1--Site Guidance, DOE/RL-93-102, U.S. Department of Energy, Richland Operations Office, Richland, Washington.

RL, 1995, Single-Shell Tank Closure Work Plan, DOE/RL-89-16, Rev. 1, U.S. Department of Energy, Richland Operations Office, Richland, Washington.

RL, 1996a, Hanford Strategic Plan, DOE/RL 96-92, Rev. 0, U.S. Department of Energy, Richland Operations Office, Richland, Washington.

RL, 1996b, Lockheed Martin Advanced Environmental Systems Private Contract, DE-AC06-96RL13309, U.S. Department of Energy, Richland Operations Office, Richland, Washington.

RL, 1996c, British Nuclear Fuels Laboratory Private Contract, DE-AC06-96RL13308, U.S. Department of Energy, Richland Operations Office, Richland, Washington. 
RL, 1996d, Project Hanford Management Contract (PHMC), DE-AC06-96-RL13200, U.S. Department of Energy, Richland Operations Office, Richland, Washington.

Root, R. W., 1998, Tank Waste Remediation System Retrieval and Disposal Mission Infrastructure PIan, HNF-1882, Rev. 0, prepared by Lockheed Martin Hanford Corporation for Fluor Daniel Hanford, Inc, Richland, Washington.

Shade, J. W., 1997, Tank Waste Remediation System Retrieval and Disposal Mission . Immobilized Low-Activity Waste Disposal Plan, HNF-1517, Rev. 0, prepared by Numatec Hanford Corporation for Fluor Daniel Hanford, Inc., Richland, Washington.

Steffen, D. H. 1996, Maintenance Optimization Plan for Essential Equipment Reliability, WHC-SP-1 179, Rev. 0, Westinghouse Hanford Company, Richland, Washington.

Strode, J. N., and V. C. Boyles, 1997, Operational Waste Volume Projection, HNF-SD-WM-ER-029, Rev. 23, prepared by Lockheed Martin Hanford Corporation for Fluor Daniel Hanford, Inc., Richland, Washington.

Swita, W. R., 1998, Tank Waste Remediation System Retrieval and disposal Mission Initial Updated Baseline, HNF-1946, Rev. 1, prepared by Lockheed Martin Hanford Corporation for Fluor Daniel Hanford, Inc., Richland, Washington.

Taylor, W. J., 1996, Concurrence with Westinghouse Hanford Company (WHC) Recommendation on Transuranic (TRU) Tank Waste Disposal (letter 96-WDD-102 to . President, Westinghouse Hanford Company, August 1), U.S. Department of Energy, Richland Operations Office, Richland, Washington.

Taylor, W. J., 1997a, Concurrence with Decision Document for the Final Disposition of Cesium and Strontium Capsules (letter 97-WDD-058.A to H. J. Hatch, Fluor Daniel Hanford, Inc., April 24), U.S. Department of Energy, Richland Operations Office, Richland, Washington.

Taylor, W. J., 1997b, Contract Number DE-AC06-96R13200 - Tank Waste Remediation System (TWRS) High-Level Waste (HLW) Canister (letter 97-WDD-146 to President, Fluor Daniel Fanford, Inc., September), U.S. Department of Energy, Richland Operations Office, Richland, Washington.

Treat, R. L., P. Bartley, T. J. McLaughlin, R. D. Potter, R. E. Raymond, and W. L. Willis, 1998, Tank Waste Remediation System Retrieval and Disposal Mission Technical Baseline Summary Description, HNF-1901, Rev. 0, prepared by Lockheed Martin Hanford Corporation for Fluor Daniel Hanford, Inc., Richland, Washington.

Wagoner, J. D., 1994, Change to Single-Shell Tank Memorandum of Agreement (letter 40517 to J. E. Baudlitz and J. E. Lytle, August 12), U.S. Department of Energy, Richland Operations Office, Richland, Washington. 
Willis, N. P., and G. C. Triner, 1993, Hanford Site Solid Waste Acceptance Criteria, WHC-EP-0063-03, Westinghouse Hanford Company, Richland, Washington.

Zimmerman, B. D., 1998, Tank Waste Remediation System Risk Management Plan, HNF-SD-WM-PMP-018, Rev. 2, prepared by Lockheed Martin Hanford Corporation for Fluor Daniel Hanford, Inc., Richland, Washington. 
HNF-SD-WM-MAR-008 Rev 3

\section{APPENDIX A}

GUIDANCE AND REQUIREMENTS TO DELIVERABLES CROSSWALK TANK WASTE REMEDIATION SYSTEM MISSION ANALYSIS REPORT 
HNF-SD-WM-MAR-008 Rev 3

This page intentionally left blank. 
HNF-SD-WM-MAR-008 Rev 3

\section{LIST OF TABLES}

A-1 Guidance and Requirements to Deliverables Crosswalk - Tank Waste Remediation System Mission Analysis Report.. . . . . . . . . . . . . . . . . . . A-1 
HNF-SD-WM-MAR-008 Rev 3

This page intentionally left blank. 
Table A-1. Guidance and Requirements to Deliverables Crosswalk -

Tank Waste Remediation System Mission Analysis Report.

\begin{tabular}{|c|c|c|}
\hline Guidance or Requirement & Status & Implementing Location \\
\hline 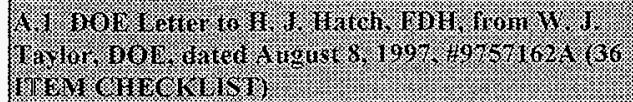 & & \\
\hline $\begin{array}{l}\text { 1. TWRS Project analysis is complete and consistent } \\
\text { with higher level plans and specifications. }\end{array}$ & I & $\begin{array}{l}\text { Mission Analysis Document is } \\
\text { complete. } 5.1 \text { Appendix B contains } \\
\text { higher-level document requirements. } \\
\text { Trace to DOE Program Plan (10-year } \\
\text { plan) will be added in next revision } \\
\text { when plan is approved by Congress. }\end{array}$ \\
\hline $\begin{array}{l}\text { 2. Requirements are identified, validated, and } \\
\text { documented. }\end{array}$ & $\mathrm{I}$ & $\begin{array}{l}\text { Sections } 5.1 \text { and 5.4; Tables 2, 3, 5, 6, } \\
7 \text {, and 8; Appendix B }\end{array}$ \\
\hline 3. Requirements are allocated to functions. & I & $\begin{array}{l}\text { Requirements allocation to functions } \\
\text { is documented in Hanford Site } \\
\text { Technical Database }\end{array}$ \\
\hline $\begin{array}{l}\text { 5. Architecture is defined based upon analyses of the } \\
\text { mission and the functions and requirements. }\end{array}$ & I & $\begin{array}{l}\text { Section 10.3; Primary architectures } \\
\text { (facilities) are also described in } \\
\text { Hanford Site Technical Database. }\end{array}$ \\
\hline $\begin{array}{l}\text { 6. All enabling assumptions have been formally } \\
\text { documented. assumptions which have been replaced } \\
\text { with facts or decisions have been changed in } \\
\text { requirements documentation. }\end{array}$ & I & $\begin{array}{l}\text { Section } 2.3 \text { discusses enabling } \\
\text { assumptions and points to documents } \\
\text { that contain them. }\end{array}$ \\
\hline $\begin{array}{l}\text { 13. Immobilized waste product project plans and } \\
\text { implementing actions and procedures are on track. }\end{array}$ & I & $\begin{array}{l}\text { Sections } 10.2 .5 \text { and } 10.2 .7 \text { describe } \\
\text { the immobilized waste product storage } \\
\text { and disposal activities in support of } \\
\text { Phase 1B. Table } 17 \text { describes facilities } \\
\text { to be used for storage and disposal } \\
\text { activities during Phase 1B. }\end{array}$ \\
\hline $\begin{array}{l}\text { 18. System reliability, availability, and maintainability } \\
\text { have been assessed and are sufficient to support } \\
\text { processing rate requirements. }\end{array}$ & I & $\begin{array}{l}\text { Section } 6.0 \text { provides an overview of } \\
\text { the TWRS Operations and } \\
\text { Maintenance strategy. }\end{array}$ \\
\hline $\begin{array}{l}\text { 29. The ability to support alternatives other than the } \\
\text { baseline has been evaluated from a programmatic } \\
\text { perspective. }\end{array}$ & I & $\begin{array}{l}\text { Section } 10.2 .4 \text { includes strategy } \\
\text { optimization recommendations. }\end{array}$ \\
\hline
\end{tabular}


Table A-1. Guidance and Requirements to Deliverables Crosswalk Tank Waste Remediation System Mission Analysis Report.

\begin{tabular}{|c|c|c|}
\hline Guidance or Requirement & Status & Implementing Location \\
\hline 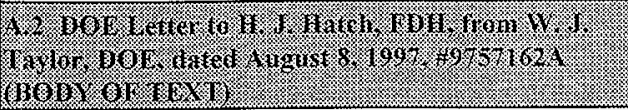 & & \\
\hline $\begin{array}{l}\text { General PHMC Responsibilities from RL's } 8 / 8 / 97 \\
\text { letter, Section } 2.1\end{array}$ & & . \\
\hline 1. Establish a sound Technical Baseline including ICDs & I & $\begin{array}{l}\text { Section } 4.3 \text { Interfaces; discusses } \\
\text { general interfaces to TWRS }\end{array}$ \\
\hline 3. An executable Programmatic Baseline exists & I & $\begin{array}{l}\text { Section } 10.0 \text { provides an analysis of } \\
\text { the Phase } 1 \text { mission baseline. Sections } \\
11.0,12.0 \text {, and } 13.0 \text { provide an } \\
\text { analysis of the Phase } 2 \text { mission } \\
\text { baseline. }\end{array}$ \\
\hline 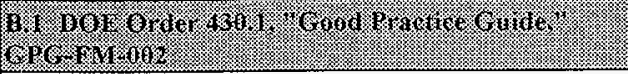 & & 8. \\
\hline \multicolumn{3}{|l|}{ 2.2.1 DOE Strategic Plan } \\
\hline 1. Program Strategic Plan & I & $\begin{array}{l}\text { DOE Program Strategic Plan (Alm } \\
\text { l0-year plan) is draft, to be approved } \\
\text { by Congress in March } 1998 \text {. } \\
\text { Requirements will be included as } \\
\text { update to MAR. Present equivalent is } \\
\text { A Hanford Strategic Plan, } \\
\text { requirements described in Appendix } \\
\text { C-4 }\end{array}$ \\
\hline 2.3.2 Funding Profile & I. & \\
\hline 2.3.3 Baseline: Work Scope (Technical) Criteria & I & \\
\hline \multicolumn{3}{|l|}{ 2.4.3 Work Scope (Technical) Criteria } \\
\hline $\begin{array}{l}\text { 1. Performance measures (see Contracting } \\
\text { Options/Acquisition Resource Planning/Application of } \\
\text { Performance Measures, GPG-FM-020). }\end{array}$ & I & Sections 9.2 and 12.2 \\
\hline \multicolumn{3}{|l|}{ 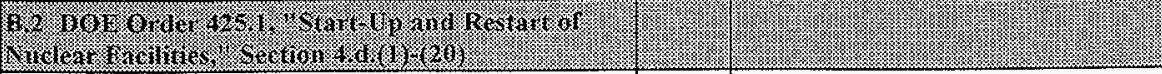 } \\
\hline $\begin{array}{l}\text { 425.1 Core Requirement (7) - DOE Order } \\
\text { Conformance }\end{array}$ & 1 & $\begin{array}{l}\text { Section } 5.1 \text { describes the PHMC as } \\
\text { the source for DOE Orders that may } \\
\text { be applicable to work and activities } \\
\text { conducted or accomplished by TWRS }\end{array}$ \\
\hline 425.1 Core Requirement (10) - Startup Test Program & I & $\begin{array}{l}\text { Section 7.0, A Test and Evaluation } \\
\text { Processes...@ }\end{array}$ \\
\hline
\end{tabular}




\begin{tabular}{|c|c|c|}
\hline 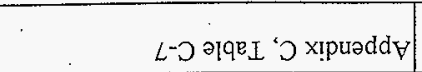 & I & 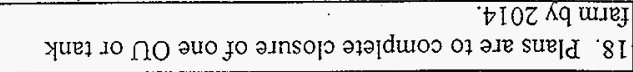 \\
\hline 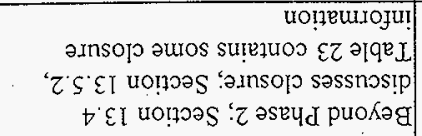 & $I$ & 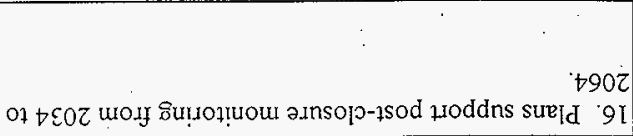 \\
\hline 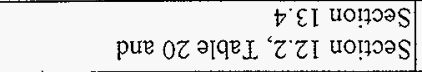 & I & 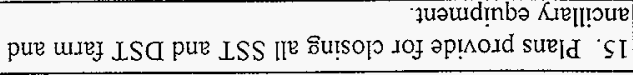 \\
\hline 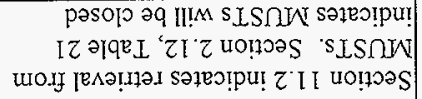 & I & 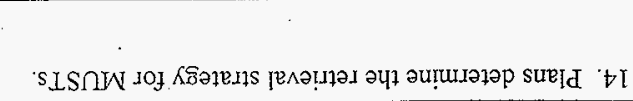 \\
\hline 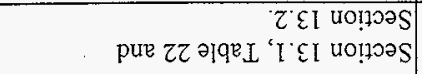 & I & 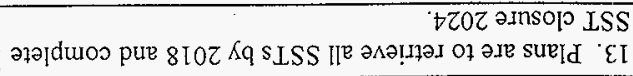 \\
\hline 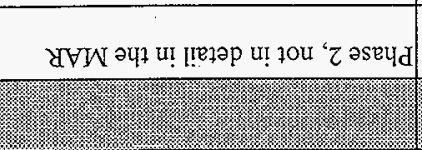 & I & 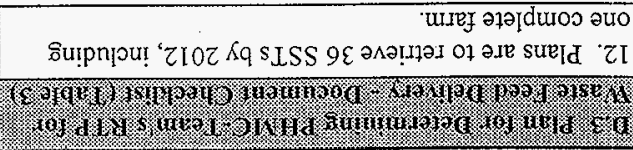 \\
\hline 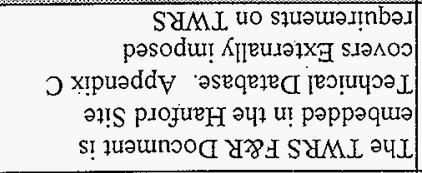 & I & 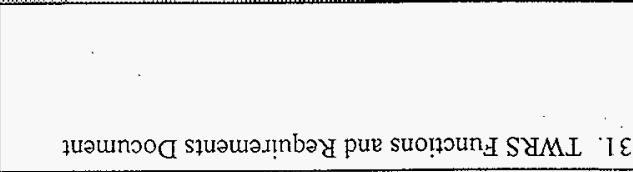 \\
\hline EI pue 'ZI 'II suoñas & $I$ & outuue Id $z$ aseyd 6 \\
\hline & $\therefore$ & 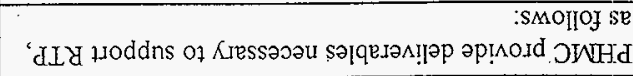 \\
\hline & & 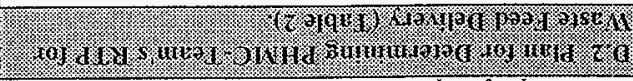 \\
\hline 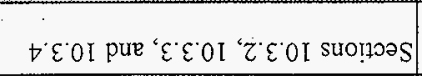 & I & 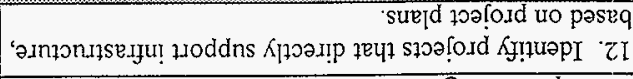 \\
\hline 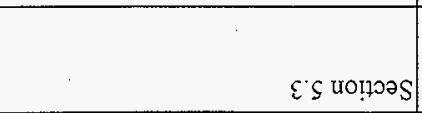 & I & 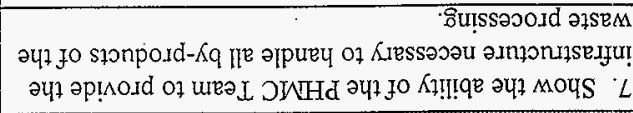 \\
\hline & & 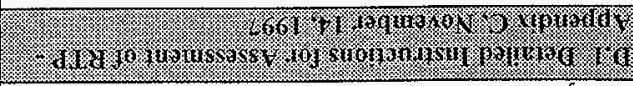 \\
\hline 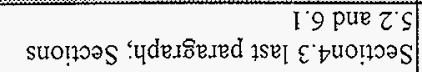 & I & 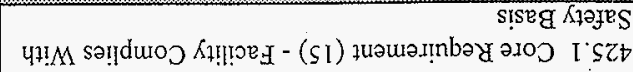 \\
\hline 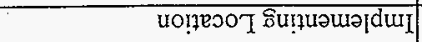 & sniets & tuวura!nboy 10 วouep!ng \\
\hline
\end{tabular}

"Iodəd s!s

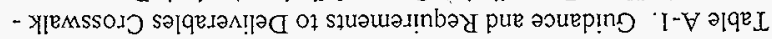


Table A-1. Guidance and Requirements to Deliverables Crosswalk Tank Waste Remediation System Mission Analysis Report.

\begin{tabular}{|c|c|c|}
\hline Guidance or Requirement & Status & Implementing Location \\
\hline $\begin{array}{l}\text { 27. Plans are for the PHMC to complete retrieval of at } \\
\text { least one tank farm and } 36 \text { SSTs. }\end{array}$ & I & Phase 2, not in detail in the MAR \\
\hline $\begin{array}{l}\text { 28. Plans are for the } 113 \text { remaining to be retrieved by a } \\
\text { private contractor, who will assume responsibility for } \\
\text { ops and maintenance of those tank farms. }\end{array}$ & $\mathrm{I}$ & $\begin{array}{l}\text { Privatization of work not currently } \\
\text { specified in MAR for Phase } 2\end{array}$ \\
\hline $\begin{array}{l}\text { 29. Plans are to transfer DST ops to a private } \\
\text { contractor in } 2012 \text {. }\end{array}$ & I & $\begin{array}{l}\text { Privatization of work not currently } \\
\text { specified in MAR for Phase } 2\end{array}$ \\
\hline $\begin{array}{l}\text { 33. Plans are for the PHMC to close tank farms; the } \\
\text { first in } 2012-2014 \text {, with turnover from the priv. cont. } \\
\text { beginning in } 2014 \text {. }\end{array}$ & I & $\begin{array}{l}\text { Privatization of work not currently } \\
\text { specified in MAR for Phase } 2\end{array}$ \\
\hline $\begin{array}{l}\text { 34. Plans are for DSTS to be turned over to the PHMC } \\
\text { for closure after Phase } 2 \text { ops are complete and tanks are } \\
\text { deactivated. }\end{array}$ & I & $\begin{array}{l}\text { Privatization of work not currently } \\
\text { specified in MAR for Phase } 2\end{array}$ \\
\hline $\begin{array}{l}\text { 54. Plans include update of retrieval and feed delivery } \\
\text { requirements required to define Phase } 2 \text { privatization. }\end{array}$ & I & $\begin{array}{l}\text { Privatization of work not currently } \\
\text { specified in MAR for Phase } 2\end{array}$ \\
\hline $\begin{array}{l}\text { 55. Plans describe providing feed delivery support to } \\
\text { the privatization requirements definition and down- } \\
\text { select process. }\end{array}$ & I & $\begin{array}{l}\text { Privatization of work not currently } \\
\text { specified in MAR for Phase } 2\end{array}$ \\
\hline $\begin{array}{l}\text { 62. Plans include formulating the requirements for } \\
\text { Subsequent SST Retrieval System (SSSTRS) Project. }\end{array}$ & I & $\begin{array}{l}\text { Not currently defined in the MAR but } \\
\text { will be analyzed when appropriate }\end{array}$ \\
\hline $\begin{array}{l}\text { 67. Plans describe submitting a detail work plan/cost est } \\
\text { for completion of closure actions, incl. approach, work } \\
\text { description, ID of tech issues/responses, turnover } \\
\text { criteria from the priv. cont., and resource-loaded } \\
\text { schedule incl. D\&D. }\end{array}$ & $I$ & \\
\hline $\begin{array}{l}\text { 68. Plans include PHMC interface w/ DOE, EPA and } \\
\text { Mggmt Sys Div (MSD) on closure strategy dev / closure } \\
\text { EIS. }\end{array}$ & I & Section 13.5 \\
\hline \multicolumn{3}{|l|}{ 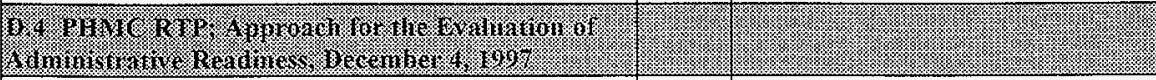 } \\
\hline $\begin{array}{l}\text { 12. Strategic \& Tactical Planning - There is a clearly } \\
\text { defined and documented approval and planning process } \\
\text { for the development of plans to achieve mission } \\
\text { objectives. }\end{array}$ & I & Entire Document \\
\hline
\end{tabular}


Table A-1. Guidance and Requirements to Deliverables Crosswalk -

Tank Waste Remediation System Mission Analysis Report.

\begin{tabular}{|c|c|c|}
\hline Guidance or Requirement & Status & Implementing Location. \\
\hline 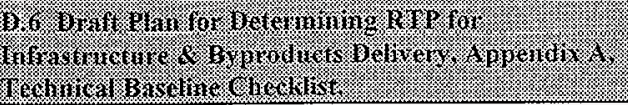 & & (2) \\
\hline $\begin{array}{l}\text { 9. Provide (on request) an Infrastructure Project } \\
\text { Mission Analysis Report which supports the TWRS and } \\
\text { Site MARs (1.1.1-1.1.2) }\end{array}$ & I & $\begin{array}{l}\text { Sections } 10.3 .2,10.3 .4 .1 \text {, and } 10.4 \\
\text { Table } 20\end{array}$ \\
\hline $\begin{array}{l}\text { 13. Show that requirements are (or will be) in the } \\
\text { Hanford Site Technical Baseline (HTSB). (3.1.4). }\end{array}$ & I & Section 8.0 \\
\hline 14. Identify verification tests in the QA Plan. (3.1.5) & I & Section 7.1 discusses test/verification \\
\hline $\begin{array}{l}\text { 15. Show requirements are allocated to functions in the } \\
\text { HSTB and Multi Year Work Plan (MYWP). }\end{array}$ & $\Upsilon$ & $\begin{array}{l}\text { Requirements tied to the MAR are } \\
\text { verified in letter } 7600-97-L G P-001, \\
\text { dated October } 15,1997 . \\
\text { Requirements tied to the projects are } \\
\text { verified in letter } 76000-97-\text { LGP-002, } \\
\text { dated December } 29,1997\end{array}$ \\
\hline 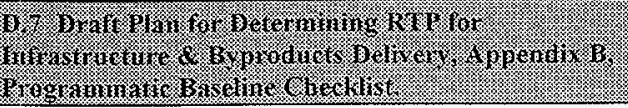 & & \\
\hline $\begin{array}{l}\text { 28. Indicate that all activities on logic diagrams are } \\
\text { tiered from contractual or MAR requirements. (1.1.1) }\end{array}$ & I & $\begin{array}{l}\text { A function of mission analysis is to } \\
\text { flow items to the logic and confirm } \\
\text { incorporation }\end{array}$ \\
\hline 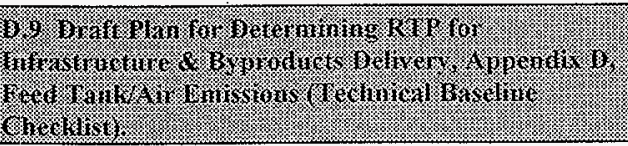 & & \\
\hline $\begin{array}{l}\text { 53. Provide (on request) an Infrastructure Project } \\
\text { Mission Analysis Report which supports the TWRS and } \\
\text { Site MARs (1.1.1-1.1.2). }\end{array}$ & I & $\begin{array}{l}\text { Infrastructure project discussed in } \\
\text { Sections } 10.3 .2,10.3 .4 .1 \text {, and } 10.4\end{array}$ \\
\hline $\begin{array}{l}\text { 57. Show that requirements are (or will be) in the } \\
\text { Hanford Site Technical Baseline (HTSB). (3.1.4) }\end{array}$ & $\mathrm{I}$ & Section 8.0 \\
\hline 58. Identify verification tests in the QA Plan. (3.1.5) & $\dot{I}$ & Section 7.1 discusses test/verification \\
\hline
\end{tabular}


Table A-1. Guidance and Requirements to Deliverables Crosswalk Tank Waste Remediation System Mission Analysis Report.

\begin{tabular}{|c|c|c|}
\hline Guidance or Requirement & Status & Implementing Location \\
\hline 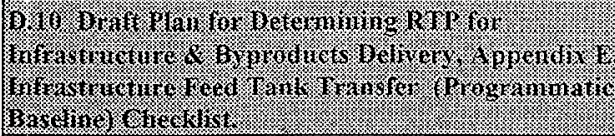 & & \\
\hline $\begin{array}{l}\text { 72. Indicate that all activities on logic diagrams are } \\
\text { tiered from contractual or MAR requirements. (1.1.1) }\end{array}$ & I & $\begin{array}{l}\text { A function of mission analysis is to } \\
\text { flow items to the logic and confirm } \\
\text { incorporation }\end{array}$ \\
\hline 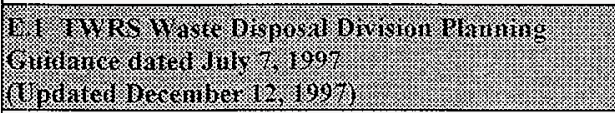 & & \\
\hline $\begin{array}{l}\text { Update the RTSD (TPA-45-02B-V) per Operations \& } \\
\text { Utilization Plan, consistent with consolidation and } \\
\text { planned feed rate requirements. }\end{array}$ & I & $\begin{array}{l}\text { Section } 10.2 \text { discusses Phase } 1 \text { waste } \\
\text { feeds }\end{array}$ \\
\hline
\end{tabular}


HNF-SD-WM-MAR-008 Rev 3

\section{APPENDIX B}

TANK WASTE REMEDIATION SYSTEM HISTORY 
HNF-SD-WMI-MAR-008 Rev 3

This page intentionally left blank.

B-ii 
HNF-SD-WM-MAR-008 Rev 3

\section{CONTENTS}

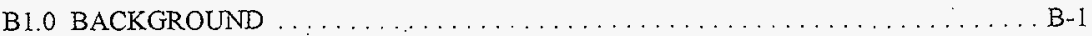

B2.0 POLICY AND PLANNING EVALUATION . . . . . . . . . . . . . . . B-1

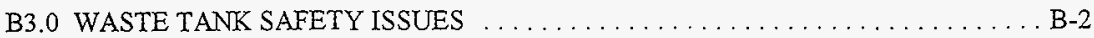

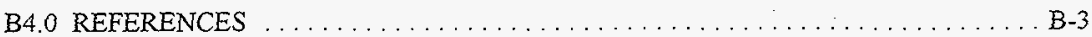

B-iii 
HNE-SD-WM-MAR-008 Rev 3

This page intentionally left blank. 


\section{TANK WASTE REMEDIATION SYSTEM HISTORY (HOW WE GOT TO WHERE WE ARE TODAY)}

\section{BL.0 BACKGROUND}

The Hanford Site was established in 1943 as part of the Manhattan Project. The mission of the Site was to produce plutonium for nuclear weapons. Over the years, nine nuclear reactors and two large areas containing several nuclear chemical processing complexes were built. The chemical processing operations produced large quantities of highly radioactive wastes. These waste materials were stored in many large underground tanks: Today, more than 204 million liters (54 Mgal) of high-level radioactive wastes are stored in 177 underground tanks.

\section{B2.0 POLICY AND PLANNING EVALUATION}

As the Hanford Site evolved and additional waste storage space was needed, additional waste tanks were built. It was recognized in the 1950 s and 1960 s that an additional effort to secure the waste was needed, particularly as leaks in some of the tanks were confirmed. But little was actually done, related to waste disposal, because of limited budgets.

In the 1970 s, the pace of planning and development for safe waste storage and disposal increased. Several formal studies of waste disposal alternatives were conducted. Research, development, and demonstration of waste treatment processes, including vitrification, were completed. Much of this work was done at the Hanford Site.

In the early 1980 s, Congress requested that the U.S. Department of Energy (DOE) plan for the disposal of the high-level waste (HLW) that had accumulated from the DOE's nuclear . activities. In 1983, the DOE issued the Defense Waste Management Plan (DOE 1983). The proposed strategy was that waste would be retrieved from storage tanks and treated to make it suitable for disposal.

Since waste retrieval and immobilization facilities costing billions of dollars would be needed, and because facilities like these had not been built before, the DOE selected a sequential approach. Facilities to treat the waste at DOE's Savannah River Site in South Carolina would be constructed first. After processing was successfully demonstrated, facilities would be built at the DOE's Fanford Site in Washington, followed by facilities at DOE's Idaho site. Waste immobilization facilities began operating at the Savannah River Site in 1996. Therefore, proceeding with waste retrieval and immobilization facilities at the Hanford Site is the next logical step in this planning progression. 
In 1987, the Hanford Defense Waste Environmental Impact Statement (DOE 1987) was issued which laid out a strategy for addressing the Hanford Site tank waste. Waste from the double-shell tanks would be retrieved. The highly radioactive fraction would be immobilized in glass (vitrified), and the low-activity waste would be solidified in cement (grout) for disposal on the Hanford Site. Further studies would be done on the single-shell tanks to determine appropriate actions. This strategy was the basis for the Hanford Federal Facility Agreement and Consent Order (Tri-Party Agreement) (Ecology et al. 1996) signed by the DOE, the Washington State Department of Ecology, and the U.S. Environmental Protection Agency in 1989 (Ecology et al. 1989).

\section{B3.0 WASTE TANK SAFETY ISSUES}

In early 1990 , issues regarding the waste in the tanks were identified that appeared to pose unacceptable risks for continued storage without corrective actions. Technical and financial resources were directed toward the resolution of these issues. The DOE considered the requirements of the Resource Conservation and Recovery Act of 1976 and the Nuclear Waste Policy Act of 1982 and decided to include retrieval and treatment of single-shell tank waste in the planning for the waste disposal program. This four-fold increase in waste volume to be treated, along with additional concerns about using an old facility (B Plant) for waste pretreatment and concerns about using the proposed grout form for low-activity waste disposal, caused a reevaluation of the strategy.

In December 1991, the Secretary of Energy directed that the Tank Waste Remediation System (TWRS) be established to plan and implement the disposal of all the Hanford Site tank waste. A systems approach was used to evaluate various alternatives. These studies were used to renegotiate the Tri-Party Agreement. A strategy was developed and negotiated and the revised Tri-Party Agreement was signed in January 1994 (Ecology et al. 1994): The strategy envisioned the following:

- Retrieval of all waste from single-shell and double-shell tanks

- Separation of the waste into high-level activity and low-activity fractions

- Immobilization of the low-activity fraction in glass or other suitable form that would reduce volume and meet long-term disposal requirements

- Vitrification of the high-level waste for disposal in a federal repository.

The revised agreement also established an enforceable milestone schedule which established objectives and which assesses progress toward completion of these actions. 
In 1994, national concern about balancing the federal budget became a more significant issue. The DOE believed that a new approach was needed for funding and managing the construction and operation of the multi-billion dollar facilities needed for waste treatment. After considering experience and input from commercial industry, the DOE decided on a "privatization" approach to accomplish tank waste treatment and immobilization at the Fanford Site.

As it is being used for TWRS, privatization is a fixed price contracting method for providing waste treatment services. The DOE will award competitively bid contracts under which the contractor will design, build, and operate immobilization facilities.

This project is divided into two phases primarily to reduce the scale-up risk and successfully demonstrate that all parties can support the activities before making a very large capital investment. The capacity of a plant to process all the waste in a reasonable time will be several times larger than anything built so far, so a demonstration phase is appropriate. This reduces the private contractors' technical risk and proves the ability to provide process waste containing the hazardous material successfully. Following Phase IB, more capacity can be added as required.

\section{B4.0 REFERENCES}

Acts

Nuclear Waste Policy Act of 1982, 42 USC 10101 et seq.

Resource Conservation and Recovery Act of 1976, 42 USC 6901 et seq.

\section{Documents}

DOE, 1983, Defense Waste Management Plan, DOE/DP-0015, U.S. Department of Energy Headquarters, Washington, D.C.

DOE, 1987, Disposal of Hanford Defense High-Level, Transuranic and Tank Wastes, Hanford Site, Richland, Washington: Final Environmental Impact Statement, DOE/EIS-0113, Vol. 1-5, U.S. Department of Energy, Washington, D.C.

Ecology, EPA, and DOE, 1989, Hanford Federal Facility Agreement and Consent Order, Washington State Department of Ecology, U.S. Environmental Protection Agency, and U.S. Department of Energy, Olympia, Washington.

Ecology, EPA, and DOE, 1994, Hanford Federal Facility Agreement and Consent Order, Washington State Department of Ecology, U.S. Environmental Protection Agency, and U.S. Department of Energy, Olympia, Washington. 


\section{HNF-SD-WM-MAR-008 Rev 3}

Ecology, EPA, and DOE, 1996, Hanford Federal Facility Agreement and Consent Order, 2 vol., Washington State Department of Ecology, U.S. Environmental Protection Agency, and U.S. Department of Energy, Olympia, Washington. 
HNF-SD-WM-MAR-008 Rev 3

APPENDIX $\mathrm{C}$

TANK WASTE REMEDIATION SYSTEM EXTERNALCY IMPOSED REQUIREMENTS

$\mathrm{C}-\mathrm{i}$ 
HNF-SD-WM-MAR-008 Rev 3

This page intentionally left blank.

C-ii 


\section{CONTENTS}

\section{LIST OF TABLES}

C-1. Tank Waste Remediation System Externally Imposed Requirements - Code of Federal Regulations

C-2. Tank Waste Remediation System Externally Imposed Requirements - Washington Administrative Code . . . . . . . . . . . . . . . . . . . . . . . . . . . C-4

C-3. Tank Waste Remediation System Externally Imposed Requirements - U.S. Department of Energy Orders and Other Federal Regulations ................... C-5

C-4. Source Document: DOE/RL-96-92, Hanford Strategic Plan . . . . . . . . . . . . . C-5

C-5. Source Document: DOE/EIS-0222D, Draft Hanford Remedial Action Environmental Impact Statement and Comprehensive Land Use Plan . . . . . . . . . . . . . C-7

C-6. Source Document: DE-AC06-96RL13200, Project Hanford Management Contract, Fluor Daniel Hanford, Inc.

C-7. Source Document: DOE/RL-89-10, Hanford Federal Facility Agreement and Consent Order (Tri-Party Agreement), Rev. 4 
HNE-SD-WM-MAR-008 Rev 3

This page intentionally left blank. 


\section{APPENDLX C}

\section{TANK WASTE REMEDIATION SYSTEM EXTERNALLY IMPOSED REQUTREMENTS}

Table C-1. Tank Waste Remediation System Externally Imposed Requirements - Code of Federal Regulations. (4 Sheets)

\begin{tabular}{|c|c|c|}
\hline \multicolumn{3}{|c|}{ Code of Federal Regulations } \\
\hline $\begin{array}{l}\text { External code or } \\
\text { regulation }\end{array}$ & Title & $\begin{array}{c}\text { Comment } \\
\text { (significant interest areas) }\end{array}$ \\
\hline 10 CFR 20 & $\begin{array}{l}\text { Standards for Protection Against } \\
\text { Radiation }\end{array}$ & - Access controls \\
\hline 10 CFR 61 & $\begin{array}{l}\text { Licensing Requirements for Land } \\
\text { Disposal of Radioactive Waste }\end{array}$ & $\begin{array}{l}\text { - Protection of the general population from releases of } \\
\text { radiation. Equivalent annual dose limits for public exposure } \\
\text { to contaminated groundwater, surface water, air, soil, plants, } \\
\text { and animals } \\
\text { - Protection of individuals trom inadvertent intrusion } \\
\text { - Burial requirements for Class } A \text { and Class } C \text { waste } \\
\text { Specifies pertinent onsite immobilized low-level waste } \\
\text { burial requirements } \\
\text { - Classification of wastes - Classitication specifications for } \\
\text { Class A and Class } C \text { waste. Designates whether } \\
\text { immobilized waste may be in general buried onsite or if it is } \\
\text { necessary to dispose of in an isolated deep repository } \\
\text { - Minimum requirements for all waste classes and are } \\
\text { intended to facilitate handing at the disposal site and } \\
\text { provide protection of health and safety of personnel at the } \\
\text { disposal site }\end{array}$ \\
\hline $10 \mathrm{CFR} 830$ & Nuclear Safety Management & $\begin{array}{l}\text { - Applicable to Quality Assurance Program, personnel } \\
\text { training, quality improvement }\end{array}$ \\
\hline 10 CFR 835 & Occupational Radiation Protection & - Occupational exposure limits for general employees \\
\hline I0 CFR 962 & By-Product Material & $\begin{array}{l}\text { - DOE obligation to RCRA - Defines DOE's obligations to } \\
\text { the RCRA with regard to radioactive waste substances }\end{array}$ \\
\hline 29 CFR 1910 & $\begin{array}{l}\text { Occupational Safety and Health } \\
\text { Standards }\end{array}$ & $\begin{array}{l}\text { - Occupational Safety and Health Standards regulations } \\
\text {.. }\end{array}$ \\
\hline
\end{tabular}


Table C-1. Tank Waste Remediation System Externally Imposed Requirements - Code of Federal Regulations. (4 Sheets)

\begin{tabular}{|c|c|c|}
\hline \multicolumn{3}{|c|}{ Code of Federal Regulations } \\
\hline $\begin{array}{l}\text { External code or } \\
\text { regulation }\end{array}$ & Title & $\begin{array}{c}\text { Comment } \\
\text { (significant interest areas) }\end{array}$ \\
\hline 40 CFR 50 & $\begin{array}{l}\text { National Primary and Secondary } \\
\text { Ambient Air Quality Standards }\end{array}$ & $\begin{array}{l}\text { - Ambient air quality standards - primary limits for sulfur } \\
\text { oxides } \\
\text { - Ambient air quality standards - secondary limits for sulfur } \\
\text { oxides } \\
\text { - Ambient air quality standards - primary and secondary } \\
\text { limits of particulate matter } \\
\text { - Ambient air quality standards - primary limits for carbon } \\
\text { monoxide } \\
\text { - Ambient air quality standards - primary and secondary } \\
\text { limits for ozone } \\
\text { - Ambient air quality standards - primary and secondary for } \\
\text { nitrogen dioxide } \\
\text { - Ambient air quality standards - primary and secondary } \\
\text { standards for lead }\end{array}$ \\
\hline 40 CFR 61 & $\begin{array}{l}\text { National Emission Standards for } \\
\text { Hazardous Air Pollutants }\end{array}$ & $\begin{array}{l}\text { - Dose limit from DOE facility. Emissions to ambient air } \\
\text { from DOE facilities will not exceed limit to any member of } \\
\text { the public in } 1 \text { year }\end{array}$ \\
\hline $40 \mathrm{CFR} 141$ & $\begin{array}{l}\text { National Primary Drinking Water } \\
\text { Regulations }\end{array}$ & - \\
\hline 40 CFR 191 & $\begin{array}{l}\text { Environmental Radiation } \\
\text { Protection Standards for } \\
\text { Management and Disposal of } \\
\text { Spent Nuclear Fuel, High-Level } \\
\text { and Transuranic Radioactive } \\
\text { Wastes }\end{array}$ & $\begin{array}{l}\text { - Public dose limits. Management and storage of spent } \\
\text { nuclear fuel, high-level, or transuranic radioactive wastes. } \\
\text { annual dose equivalents to any member of the public in the } \\
\text { general environment. }\end{array}$ \\
\hline
\end{tabular}


HNF-SD-WM-MAR-008 Rev.3

Table C-1. Tank Waste Remediation System Externally Imposed Requirements - Code of Federal Regulations. (4 Sheets)

\begin{tabular}{|c|c|c|}
\hline \multicolumn{3}{|c|}{ Codc of Federal Regulations } \\
\hline $\begin{array}{l}\text { External code or } \\
\text { regulation }\end{array}$ & Title & $\begin{array}{c}\text { Comment } \\
\text { (significant interest areas) }\end{array}$ \\
\hline 40 CFR 264 & $\begin{array}{l}\text { Standards for Owners and } \\
\text { Operators of Hazardous Waste } \\
\text { Treatment, Storage, and Disposal } \\
\text { Facilities }\end{array}$ & $\begin{array}{l}\text { - Storage requirements - Hazardous wastes must not be } \\
\text { placed in tank system if they could cause the tank or } \\
\text { associated ancillary equipment and containment system to } \\
\text { trpture, leak, corrode, or otherwise fail } \\
\text { - Storage requirements - The owner or operator must use } \\
\text { appropriate controls and practices to prevent spills and } \\
\text { overtlows from tank to containment systems } \\
\text { - Storage requirements - Ignitable or reactive waste must } \\
\text { not be placed in tank systems, unless: (1) the waste is } \\
\text { treated, rendered, or mixed so that the waste is protected } \\
\text { from a material or condition that may cause the waste to } \\
\text { ignite or react or } 40 \text { CFR } 264.17 \text { (b) is complied with, or } \\
\text { (2) the tank system is used solely for emergencies. Stored } \\
\text { ignitable or reactive wastes must comply with requirement } \\
\text { for protective distances from the public. } \\
\text { - Storage requirements - Incompatible wastes or } \\
\text { incompatible wastes and materials must not be placed in } \\
\text { same tank system, unless } 40 \text { CFR } 264.17 \text { (b) is complied } \\
\text { with } \\
\text { - Closure requirement - Decontamination at closure of a } \\
\text { containment building. Owner/operator must decontaminate } \\
\text { all waste residues, contaminated containment system } \\
\text { components (liners, etc.), contaminated soils, and structures } \\
\text { and equipment contaminated with waste and leachate, and } \\
\text { manage as a hazardous waste. } \\
\text { - Waste containment system closure requirements. At } \\
\text { losure, all hazardous waste and hazardous waste residues } \\
\text { must be removed from the containment system, Remaining } \\
\text { containers, liners, bases, and soil containing or } \\
\text { contaminated with hazardous waste or residues must be } \\
\text { decontaminated or removed. }\end{array}$ \\
\hline $40 \mathrm{CFR} 265$ & $\begin{array}{l}\text { Interim Status Standards for } \\
\text { Owners and Operators of } \\
\text { Hazardous Waste Treatment, } \\
\text { Storage, and Disposal Facilities }\end{array}$ & $\begin{array}{l}\text { - Secondary containment } \\
\text { - Spill convention and controls } \\
\text { - Incompatible/ignitable wastes }\end{array}$ \\
\hline
\end{tabular}


HNF-SD-WM-MAR-008 Rev 3

Table C-1. Tank Waste Remediation System Externally Imposed Requirements - Code of Federal Regulations. (4 Sheets)

\begin{tabular}{|c|c|c|}
\hline \multicolumn{3}{|c|}{ Code of Federal Regulations } \\
\hline $\begin{array}{l}\text { External code or } \\
\text { regulation }\end{array}$ & Title & $\begin{array}{c}\text { Comment } \\
\text { (significant interest areas) }\end{array}$ \\
\hline $\begin{array}{c}40 \text { CFR } 268 \\
=\end{array}$ & Land Disposal Restrictions & $\begin{array}{l}\text { - Applicable exceptions for which otherwise prohibited } \\
\text { wastes may be disposed of in a landfill } \\
\text { - Certain wastes prohibited from land disposal } \\
\text { - Applicability of treatment standards }\end{array}$ \\
\hline 40 CFR 279 & $\begin{array}{l}\text { Standards for the Management of } \\
\text { Used Oil }\end{array}$ & - Used oil handing \\
\hline 40 CFR 761 & $\begin{array}{l}\text { Polychlorinated Biphenyls (PCBs), } \\
\text { Manufacturing, Processing, } \\
\text { Distribution in Commerce, and } \\
\text { Use Prohibitions }\end{array}$ & -- \\
\hline
\end{tabular}

$\mathrm{CFR}=$ Code of Federal Regulations.

DOE $=$ U.S. Department of Encrgy.

$\mathrm{RCRA}=$ Resource Conservation and Recovery $/$ iat of 1976

Table C-2. Tank Waste Remediation System Externally Imposed Requirements - Washington Administrative Code.

\begin{tabular}{|c|c|c|}
\hline \multicolumn{3}{|c|}{ Washington Administrative Code } \\
\hline $\begin{array}{l}\text { External code or } \\
\text { regulation }\end{array}$ & Title & $\begin{array}{l}\text { Comment } \\
\text { (significant interest areas) }\end{array}$ \\
\hline WAC 173-200 & $\begin{array}{l}\text { Water Quality Standards for Ground } \\
\text { Waters of the State of Washington }\end{array}$ & - Liquid effluent discharge to the environment \\
\hline WAC 173-201A & $\begin{array}{l}\text { Water Quality Standards for Surface } \\
\text { Waters of the State of Washington }\end{array}$ & - Liquid effluent discharge to the environment \\
\hline WAC 173-303 & Dangerous Waste Regulations & $\therefore$ \\
\hline WAC $173-360$ & Underground Storage Tank Regulations & - Secondary containment and leak detection \\
\hline WAC $173-400$ & $\begin{array}{l}\text { General Regulations for Air Pollution } \\
\text { Sources }\end{array}$ & $\begin{array}{l}\text { - Nonradioactive air emissions, new source } \\
\text { review/notice of construction, source registration }\end{array}$ \\
\hline WAC $173-401$ & Operating Permit Regulation & -- \\
\hline WAC $173-460$ & $\begin{array}{l}\text { Controls for New Sources of Toxic Air } \\
\text { Pollutants }\end{array}$ & - Nonradioactive air emissions, toxic air pollutants \\
\hline WAC $173-480$ & $\begin{array}{l}\text { Ambient Air Quality Standards and } \\
\text { Enission Limits for Radionuclides }\end{array}$ & $\because$ \\
\hline WAC $246-247$ & Radiation Protection--Air Emissions & $\begin{array}{l}\text { - Ambient air quality standards and emission } \\
\text { standards will be those promulgated by Ecology in } \\
\text { WAC } 173-480\end{array}$ \\
\hline
\end{tabular}


Table C-3. Tank Waste Remediation System Externally Imposed Requirements U.S. Department of Energy Orders and Other Federal Regulations.

\begin{tabular}{|c|c|c|}
\hline \multicolumn{3}{|c|}{ Doe Orders and other federal regulations } \\
\hline $\begin{array}{l}\text { External code or } \\
\text { regulation }\end{array}$ & Title & $\begin{array}{l}\text { Comment } \\
\text { (significant interest areas) }\end{array}$ \\
\hline \multicolumn{3}{|c|}{$\begin{array}{l}\text { See the PHMC contract, * Appendix C, Section J, Part III - List of Documents Exhibits and Other Attachments, DOE } \\
\text { Orders and Directives. (NOTE: This list is still undergoing change so it is necessary to refer to the latest list from } \\
\text { Contracting to obtain a complete listing of all the codes.) }\end{array}$} \\
\hline \multicolumn{3}{|c|}{ Other regulations and requirements } \\
\hline $\begin{array}{l}\text { External code or } \\
\text { regulation }\end{array}$ & Title & $\begin{array}{c}\text { Comment } \\
\text { (significant interest areas) }\end{array}$ \\
\hline RCRA-B(DW)(940829) & $\begin{array}{l}\text { Dangerous Waste Portion of the } \\
\text { RCRA Permit for the Treatment, } \\
\text { Storage, and Disposal of Flazardous } \\
\text { Waste }\end{array}$ & $\begin{array}{l}\text { - Standards for hazardous treatment, storage, } \\
\text { and/or disposal facilities }\end{array}$ \\
\hline $\begin{array}{l}\text { Project Hanford policies } \\
\text { and procedures }\end{array}$ & (Numerous) & -- \\
\hline $\begin{array}{l}\text { Hanford Site Radiological } \\
\text { Control Manual, } \\
\text { Sections } 111,112\end{array}$ & - & - Summary of health and safety regulations \\
\hline PNNL-11107 & $\begin{array}{l}\text { Climatological Data Summary } 1995 \\
\text { with Flistorical Data - Hanford Site }\end{array}$ & -- \\
\hline
\end{tabular}

*RL, 1996, Project Hanford Wantrgement Contract (PHM/C), DE-AC06-96RL13200, U.S. Deparment of Energy, Richland Operations Office, Richland, Washington.

Table C-4. Source Document: DOE/RL-96-92, Hanford Strategic Plan. (2 Sheets)

\begin{tabular}{|l|l|}
\hline $\begin{array}{c}\text { HSTD } \\
\text { reference }\end{array}$ & \multicolumn{1}{|c|}{ Extracted requirement } \\
\hline $\begin{array}{l}\text { HSP.CP. } \\
\text { GOAL }\end{array}$ & $\begin{array}{l}\text { Area Goal - Central Plateau The } 200 \text { Areas and Central Plateau will be used for the } \\
\text { management of nuclear materials and the collection and disposal of waste materials that remain } \\
\text { onsite and for other related and compatible uses. Cleanup levels and disposal standards will be } \\
\text { established that are consistent with these long-term uses. }\end{array}$ \\
\hline HSP.ET.4.B & $\begin{array}{l}\text { Endpoint Target - Facilities (B) Transition high-cost surplus facilities in the Central Plateau } \\
\text { and south } 600 \text { Aueas to a low-cost, stable, deactivated condition. }\end{array}$ \\
\hline HSP.ET.6.A & $\begin{array}{l}\text { Endpoint Target - Tank Waste (A) Retrieve tank wastes to the extent needed for tank closure, } \\
\text { divide into high-level and low-activity fractions and immobilize. }\end{array}$ \\
\hline HSP.ET.6.B & $\begin{array}{l}\text { Endpoint Target - Tank Waste (B) The immobilized low-activity fraction will be disposed } \\
\text { onsite in a } 200 \text { Area disposal system. }\end{array}$ \\
\hline HSP.ET.6.C & $\begin{array}{l}\text { Endpoint Target - Tank Waste (C) The high-level immobilized fraction will be interim stored } \\
\text { until it cun be shipped offsite lor disposal (planned for the Yucca Mountain geologic repository). }\end{array}$ \\
\hline HSP.ET.6.D & $\begin{array}{l}\text { Endpoint Target - Tank Waste (D) For cesium/strontium capsules declared waste, send to } \\
\text { Yucca Mountain for HLW repository disposal. }\end{array}$ \\
\hline
\end{tabular}


Table C-4. Source Document: DOE/RL-96-92, Hanford Strategic Plan. (2 Sheets)

\begin{tabular}{|c|c|}
\hline $\begin{array}{l}\text { HSTD } \\
\text { reference }\end{array}$ & Extracted requirement \\
\hline HSP.ET.6.E & $\begin{array}{l}\text { Endpoint Target - Tank Waste (E) After the waste has been retrieved from the tanks, the tank } \\
\text { farms (including the tanks) will be closed. }\end{array}$ \\
\hline HSP.SW.B & $\begin{array}{l}\text { Material Category Goal - Solid Waste (B) The Hanford Site will continue to receive onsite and } \\
\text { ofisite wastes for disposal in the } 200 \text { Area. }\end{array}$ \\
\hline HSP.TW.A & $\begin{array}{l}\text { Material Category Goal - Tank Waste (A) Tank waste from SSTs and DSTs will be retrieved } \\
\text { for immobilization. }\end{array}$ \\
\hline HSP.TW.B & $\begin{array}{l}\text { Material Category Goal - Tank Waste (B) Waste will be separated into HLW and LAW } \\
\text { fractions. }\end{array}$ \\
\hline HSP.TW.C & Material Category Goal - Tank Waste (C) LAW will be immobilized and disposed of onsite. \\
\hline HSP.TW.D & $\begin{array}{l}\text { Material Category Goal - Tank Waste (D) HLW will be immobilized for disposal in an offsite } \\
\text { federal repository. }\end{array}$ \\
\hline HSP.FAC.C & $\begin{array}{l}\text { Material Category Goal - Facilities (C) Surplus facilities will be decommissioned and } \\
\text { decontaminated sufficiently to enable removal or closure through entombment. }\end{array}$ \\
\hline $\begin{array}{l}\text { HSP.KEY. } \\
\text { PLAN.3.B }\end{array}$ & $\begin{array}{l}\text { Key Planning Assumption - Onsite interim storage Onsite interim safe, stable storage (of } \\
\text { nuclear materials and HLW) will be required. }\end{array}$ \\
\hline HSP.KPA. 2 & $\begin{array}{l}\text { Key Planning Assumptions - Store HLW Onsite interim safe, stable storage of nuclear } \\
\text { materiais and HLW will be required. }\end{array}$ \\
\hline
\end{tabular}
Washington.

Source: KL, 1996, Hanford Strategic Plan, DOE/RL 96-92. Rev. 0, U.S. Department of Energy, Richland Operations Office, Richland,

DST $=$ double-shell tank

HLW $=$ high-level waste

HSTD $=$ Hanford Site Tecluical Baseline Database

LAW $=$ low-activity wastc.

SST = single-shell tank. 
Table C-5. Source Document: DOE/EIS-0222D, Draft Hanford Remedial Action Environmental Impact Statement and Comprehensive Land Use Plan.

\begin{tabular}{|c|c|}
\hline $\begin{array}{l}\text { HSTD } \\
\text { reference }\end{array}$ & Extracted reference \\
\hline CLUP.5.3.2 200 & $\begin{array}{l}\text { Area/Central Plateau EM Goal The } 200 \text { Area and the Central Plateau will be } \\
\text { used for management of nuclear materials, collection and disposal of waste } \\
\text { materials that remain onsite, and other related and compatible uses. Remediation } \\
\text { levels and disposal standards that are consistent with long-term uses will be } \\
\text { established. }\end{array}$ \\
\hline CLUP.5.3.2.1NT.3200 & $\begin{array}{l}\text { Area/Central Plateau EM Goal (C) The } 200 \text { Area and the Central Plateau will be } \\
\text { used for disposal of waste materials that remain onsite, and other related and } \\
\text { compatible uses. }\end{array}$ \\
\hline CLUP.5.3.2.1NT.4 200 & $\begin{array}{l}\text { Area/Central Plateau EM Goal (D) Rernediation levels and disposal standards } \\
\text { that are consistent with long-term uses for the Central Plateau will be established }\end{array}$ \\
\hline CLUP.5.3.2.b & $\begin{array}{l}200 \text { Arca/Central Plateau EM Goal - Tank Waste Retrieve and vitrify. Dispose } \\
\text { of HLW offsite. Onsite disposal of LLW. Tank farms closed. }\end{array}$ \\
\hline CLUP.5.3.2.b.1NT. & $\begin{array}{l}200 \text { Area/Central Plateau EM Goal - Tank Waste (A) Tank waste will be } \\
\text { retrieved from } 200 \text { Area underground waste storage tanks. }\end{array}$ \\
\hline CLUP.5.3.2.b.1NT.2 & $\begin{array}{l}200 \text { Area/Central Plateau EM Goal - Tank Waste (B) Retrieved tank waste } \\
\text { will be vitrified to make disposal ready. }\end{array}$ \\
\hline CLUP.5.3.2.b.1NT.3 & $\begin{array}{l}200 \text { Area/Central Plateau EM Goal - Tank Waste(C) Vitrified HLW will be } \\
\text { disposed of offsite. }\end{array}$ \\
\hline CLUP.5.3.2.6.1NT.4 & $\begin{array}{l}200 \text { Area/Central Plateau EM Goal - Tank Waste (D) Vitrified LLW will be } \\
\text { disposed onsite. }\end{array}$ \\
\hline CLUP.5.3.2.b.1NT.5 & $\begin{array}{l}200 \text { Area/Central Plateau EM Goal - Tank Waste (E) Tank farms will be } \\
\text { closed. }\end{array}$ \\
\hline CLUP.5.3.2.f & $\begin{array}{l}200 \text { Area/Central Plateau EM Goal - Facilities Transition production facilities } \\
\text { to stable deactivated conditions. Entomb process facilities in place, with co- } \\
\text { disposal of waste materials. Dismantle other facilities. }\end{array}$ \\
\hline
\end{tabular}

Source: DOE, 1996. Draft Hanford Remedial Action Emimonnental Impact Statement and Comprehensive Land Use Plan, DOE/EIS-0222D, U.S. Depastment of Eucrgy. Washitigton. D.C.

EMI = U.S. Department of Energy, Onice of Eurironmental Restoration and Management.

$\mathrm{HLW}=$ high-level waste.

HSTD $=$ Hanford Site Technical Baseline Database.

LLWV $=$ low-level waste. 
Table C-6. Source Document: DE-AC06-96RL13200, Project Hanford Management Contract, Fluor Daniel Hanford, Inc.

\begin{tabular}{|c|c|c|}
\hline $\begin{array}{l}\text { HSTD } \\
\text { reference }\end{array}$ & \multicolumn{2}{|l|}{ Extracted reference } \\
\hline TWR. 1.2 .2 & \multicolumn{2}{|c|}{$\begin{array}{l}\text { TWR1.2.2 Complete installation of continuous temperature monitoring system on remaining } \\
\text { organic tanks. }\end{array}$} \\
\hline TWR.1.3.1 & \multicolumn{2}{|c|}{$\begin{array}{l}\text { TWR1.3.1 Complete retained gas sampling in tanks AW-101, AN-102, AN-104, AN-105, and U- } \\
103 \text { and provide reconumendation for future deployment. }\end{array}$} \\
\hline TWR.1.3.5 & \multicolumn{2}{|c|}{$\begin{array}{l}\text { TWR1.3.5 Complete installation of } 15 \text { new and } 2 \text { existing spare standard hydrogen monitor } \\
\text { systems on additional flammable gas tanks. }\end{array}$} \\
\hline TWR 1.4 .1 & \multicolumn{2}{|c|}{$\begin{array}{l}\text { TWR1.4.1 Remove sufficient high-heat sludge from tank } \mathrm{C}-106 \text { to eliminate the need for periodic } \\
\text { water additions. }\end{array}$} \\
\hline TWR.4.1.1 & \multicolumn{2}{|l|}{ TWR4.1.1 Stage waste to reduce waste volume. } \\
\hline TWR.4.1.4 & \multicolumn{2}{|l|}{ TWR4.1.4 Install the new pump in tank 104-AW. } \\
\hline TWR.4.1.5 & \multicolumn{2}{|l|}{ TWR4.1.5 Install tank monitoring and control system in the AW Tank Farm. } \\
\hline TWR. 4.1.6 & \multicolumn{2}{|l|}{ TWR4.1.6 Install the jumper manifold in the AW Tank Farm. } \\
\hline TWR.5.1.3 & \multicolumn{2}{|c|}{ TWR5.1.3 Operate the mixer punp in tank 101-SY to mitigate the flammable gas safety issue. } \\
\hline TWR.5.1.7 & \multicolumn{2}{|c|}{$\begin{array}{l}\text { TWR5.1.7 Maintain the capability to manage double-shell tank space in the West Tank Farms by } \\
\text { ensuring at least one existing cross-site transfer system from the } 200 \text { West Area to the } 200 \text { East } \\
\text { Area is leak tight. }\end{array}$} \\
\hline TWR.5.1.8 & \multicolumn{2}{|c|}{$\begin{array}{l}\text { TWR5.1.8 Support vadose zone characterization in S and SX tank farms by achieving } \\
\text { performance completion criteria. }\end{array}$} \\
\hline TWR.5.2.2 & \multicolumn{2}{|c|}{ TWR5.2.2 Complete Project W-303, Tank Farms Ventilation Upgrades, and begin operation. } \\
\hline TWR.5.2.3 & \multicolumn{2}{|l|}{ TWR5.2.3 Complete construction of the cross-site transfer system. } \\
\hline \multicolumn{3}{|c|}{ 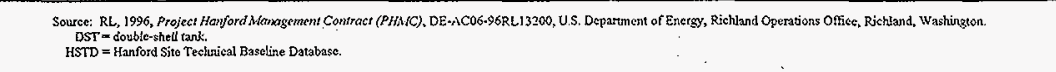 } \\
\hline Table C-7. & \multicolumn{2}{|c|}{$\begin{array}{l}\text { Source Document: DOE/RL-89-10, Hanford Federal Facility Agreement and } \\
\text { Consent Order (Tri-Party Agreement), Rev. 4. ( } 5 \text { Sheets) }\end{array}$} \\
\hline $\begin{array}{l}\text { HSTD } \\
\text { reference }\end{array}$ & Extracted requirement & Due date \\
\hline TPA.M.17.0.B & $\begin{array}{l}\text { Phase Il Liquid Etfluents BAT/AKART Complete implementation } \\
\text { of best available technology/all known, available, and reasonable } \\
\text { methods of prevention, control, and treatment (BAT/AKART) for } \\
\text { Phase } 1 \text { liquid effluent streams at the Hanford Site. }\end{array}$ & $10 / 31 / 1997$ \\
\hline TPA.M.20.57 & $\begin{array}{l}\text { ILAW Facility Part B Permit Submit Interim ILAW Facility Part B } \\
\text { Dangerous Waste Permit Application to Ecology. }\end{array}$ & $12 / 31 / 2000$ \\
\hline
\end{tabular}


Table C-7. Source Document: DOE/RL-89-10, Hanford Federal Facility Agreement and Consent Order (Tri-Party Agreement), Rev. 4. (5 Sheets)

\begin{tabular}{|c|c|c|}
\hline $\begin{array}{l}\text { HSTD } \\
\text { reference }\end{array}$ & Extracted requirement & Due date \\
\hline TPA.M:20.58 & $\begin{array}{l}\text { Submit LAW Facility Part B Dangerous Waste Perinit } \\
\text { Application to Ecology. }\end{array}$ & $12 / 31 / 2003$ \\
\hline TPA.M.32.6 & $\begin{array}{l}\text { 244-AR Vault Tank Actions Complete } 244-A R \text { vault interim stątus } \\
\text { tank actions. }\end{array}$ & TBD \\
\hline TPA.M.40.0 & $\begin{array}{l}\text { Tank Safety Issues Mitigate (resolve) tank safety issues for } \\
\text { high-priority watch list tanks. }\end{array}$ & $9 / 30 / 2001$ \\
\hline TPA.M.41.0.a & SST Interim Stabilization Complete SST interim stabilization. & $9 / 30 / 2000$ \\
\hline TPA.M.41.0.b & $\begin{array}{l}\text { SST Intrusion Complete intrusion prevention for all SSTs except } \\
\text { tank C-106. }\end{array}$ & $9 / 30 / 2000$ \\
\hline TPA.M.43.0 & Complete Tank Farm Ũpgrades & $6 / 30 / 2005$ \\
\hline TPA.M.43.1 & $\begin{array}{l}\text { Tank Farm Ventilation Upgrade (W-030) Complete } \\
\text { Project W-030 tank farm ventilation upgrades, }\end{array}$ & $12 / 31 / 1997$ \\
\hline TPA.M.43.1.C & W-030 0peration Begin operation of Project W- 030 . & 10/31/1997 \\
\hline TPA.M.43.7 & $\begin{array}{l}\text { Cross-Site Transfer System Replacement Complete } \\
\text { Project W-058 replacement of cross-site transfer system. }\end{array}$ & $2 / 28 / 1998$ \\
\hline TPA.M.43.7.B & Construct W-058 Complete construction of Project W-058. & $8 / 31 / 1997$ \\
\hline TPA.M.43.7.C & $\begin{array}{l}\text { Cross-Site Transfer System Operational Cross-site transfer } \\
\text { system operational. }\end{array}$ & $2 / 28 / 1998$ \\
\hline TPA.M.43.12 & $\begin{array}{l}\text { Construction Upgrades } 1999 \text { Start construction for upgrades in the } \\
\text { first tank farm. }\end{array}$ & $6 / 30 / 1999$ \\
\hline TPA.M.43.13 & $\begin{array}{l}\text { Construction Upgrades } 2000 \text { Start construction for upgrades in the } \\
\text { second tank farm. }\end{array}$ & $6 / 30 / 2000$ \\
\hline TPA.M.43.14 & $\begin{array}{l}\text { Construction Upgrades } 2001 \text { Start construction for upgrades in the } \\
\text { third tank farm. }\end{array}$ & $3 / 31 / 2001$ \\
\hline TPA.M.43.15 & $\begin{array}{l}\text { Construction Upgrades } 2002 \text { Start construction for upgrades in the } \\
\text { fourth tank farm. }\end{array}$ & $3 / 31 / 2002$ \\
\hline TPA.M.43.16 & $\begin{array}{l}\text { Construction Upgrades } 2003 \text { Start construction for upgrades in the } \\
\text { fifth tank farm. }\end{array}$ & $6 / 30 / 2003$ \\
\hline TPA.M.45.0 & SST Closure Complete closure of all SST farms. & $9 / 30 / 2024$ \\
\hline TPA.M.45.3.A.a & $\begin{array}{l}\text { Tank C-106(a) Initiate sluicing retrieval of tank C-106 to resolve } \\
\text { the high-heat safety issue. }\end{array}$ & $10 / 31 / 1997$ \\
\hline TPA.M.45.3.A.b & $\begin{array}{l}\text { Tank C-106(b) Initiate sluicing retrieval of tank C-106 to } \\
\text { demonstrate waste retrieval. }\end{array}$ & $10 / 31 / 1997$ \\
\hline
\end{tabular}


Table C-7. Source Document: DOE/RL-89-10, Hanford Federal Facility Agreement and Consent Order (Tri-Party Agreement), Rev. 4. (5 Sheets)

\begin{tabular}{|c|c|c|}
\hline $\begin{array}{l}\text { HSTD } \\
\text { reference }\end{array}$ & Extracted requirement & Due date \\
\hline TPA.M.45.3.T.1 & SST Waste Retrieval Complete SST waste retrieval demonstration. & $9 / 30 / 2003$ \\
\hline TPA.M.45.3.T.2 & $\begin{array}{l}\text { Tank C-106 Retricyal Domonstration Initiate final retrieval } \\
\text { demonstration of tank } C-106 \text {. }\end{array}$ & $6 / 30 / 2002$ \\
\hline TPA.M.45.4.T.1 & $\begin{array}{l}\text { SST Initial Retrieval Systems Provide initial SST retrieval } \\
\text { systems. }\end{array}$ & $11 / 30 / 2003$ \\
\hline TPA.M.45.4.T.3 & $\begin{array}{l}\text { SST Retrieval Systems Complete construction for the initial SST } \\
\text { retrieval systems }\end{array}$ & $6 / 30 / 2003$ \\
\hline TPA.M.45.5 & SST Retrieval Relrieve waste fiom all remaining SSTs. & $9 / 30 / 2018$ \\
\hline TPA.M.45.5.T.1 & SST Retrieval (2003) Initiate tank waste retrieval from one SST. & $12 / 31 / 2003$ \\
\hline TPA.M.45.5.T.2 & $\begin{array}{l}\text { SST Retricval (2004) Initiate tank waste retrieval from two } \\
\text { additional SSTs. }\end{array}$ & $9 / 30 / 2004$ \\
\hline TPA.M.45.5.T.3 & $\begin{array}{l}\text { SST Retrieval (2005) Initiate tank waste retrieval from three } \\
\text { additional SSTS. }\end{array}$ & $9 / 30 / 2005$ \\
\hline TPA.M.45.5.T.4 & $\begin{array}{l}\text { SST Retrieval (2006) Initiate tank waste retrieval from four } \\
\text { additional SSTs. }\end{array}$ & $9 / 30 / 2006$ \\
\hline TPA.M.45.5.T.5 & $\begin{array}{l}\text { SST Retrieval (2007) Initiate tank waste retrieval from five } \\
\text { additional SSTs. }\end{array}$ & $9 / 30 / 2007$ \\
\hline TPA.M.45.5.T.6 & $\begin{array}{l}\text { SST Retrieval (2008) Initiale tank waste retrieval from five } \\
\text { additional SSTs. }\end{array}$ & $9 / 30 / 2008$ \\
\hline TPA.M.45.5.T.8 & $\begin{array}{l}\text { SST Retrieval (2010) Initiate tank waste retrieval from eight } \\
\text { additional SSTS. }\end{array}$ & $9 / 30 / 2010$ \\
\hline TPA.M.45.5.T.9 & $\begin{array}{l}\text { SST Retrieval (2011) Initiate tank waste retrieval from ten } \\
\text { additional SSTs. }\end{array}$ & $9 / 30 / 2011$ \\
\hline TPA.M.45.5.T.10 & $\begin{array}{l}\text { SST Retrieval (2012) Initiate tank waste retrieval from } 12 \\
\text { additional SSTs. }\end{array}$ & $9 / 30 / 2012$ \\
\hline TPA.M.45.5.T.11 & $\begin{array}{l}\text { SST Retrieval (2013) Initiate tank waste retrieval from } 14 \\
\text { additional SSTs. }\end{array}$ & $9 / 30 / 2013$ \\
\hline TPA.M.45.5.T.12 & $\begin{array}{l}\text { SST Retrieval (2014) Initiate tank waste retrieval from } 17 \\
\text { additional SSTs. }\end{array}$ & $9 / 30 / 2014$ \\
\hline TPA.M.45.5.T.13 & $\begin{array}{l}\text { SST Retrieval (2015) Initiate tank waste retrieval from } 20 \\
\text { additional SSTs. }\end{array}$ & $9 / 30 / 2015$ \\
\hline TPA.M.45.5.T. 14 & $\begin{array}{l}\text { SST Retrieval (2016) Initiate tank waste retrieval from } 20 \\
\text { additional SSTs. }\end{array}$ & $9 / 30 / 2016$ \\
\hline
\end{tabular}


Table C-7. Source Document: DOE/RL-89-10, Hanford Federal Facility Agreement and Consent Order (Tri-Party Agreement), Rev. 4. (5 Sheets)

\begin{tabular}{|c|c|c|}
\hline $\begin{array}{l}\text { HSTD } \\
\text { reference }\end{array}$ & Extracted requirement & Due date \\
\hline TPA.M.45.5.T.15 & $\begin{array}{l}\text { SST Retrieval (2017) Initiate tank waste retrieval from } 20 \\
\text { additional SSTs. }\end{array}$ & $9 / 30 / 2017$ \\
\hline TPA.M.45.6 & $\begin{array}{l}\text { SST Closure M-45-06 9/30/2024 Complete closure of all SST } \\
\text { farms. The SST closure work plan will be prepared describing the } \\
\text { work integration process for SST closures and status of work and } \\
\text { integration process. Known issues will be identified and an } \\
\text { explanation will be given on how these issues are being addressed. } \\
\text { This work plan will be provided to Ecology for review/comment and } \\
\text { will be used as a roadmap for closure of the SSTs. Because of the } \\
\text { uncertainties in the closure process, the work plan will evolve as } \\
\text { these uncertainties are resolved and eventually it will become the SST } \\
\text { closure/post-closure plan(s) isstied for Ecology's approval under } \\
\text { subsequent Tri-Party Agreement interim milestones. Major work } \\
\text { areas covered in the work plan will include waste retrieval, operable } \\
\text { units claracterization, technology development to support closure, } \\
\text { regulatory pathway, and strategy for achieving closure. }\end{array}$ & - \\
\hline TPA.M.45.6.T.2 & $\begin{array}{l}\text { Demo Tank Farm Closure Plan Ecology will issue final } \\
\text { closure/post-closure plan for selected closure demonstration operable } \\
\text { unit or tank farm. }\end{array}$ & $9 / 30 / 2006$ \\
\hline $\begin{array}{l}\text { TPA.M.45.6.T.3 } \\
\qquad\end{array}$ & $\begin{array}{l}\text { Initiate Closure Actions Initiate closure actions on an operable unit } \\
\text { or tank farm basis. Closure will follow completion of the retrieval } \\
\text { actions under proposed Milestone } \mathrm{M}-45-05 \text {. Closure will be defined } \\
\text { in an approved closure plan for the demonstration farm. Final closure } \\
\text { is defined as regulatory approval of completion of closure actions. }\end{array}$ & $3 / 31 / 2012$ \\
\hline TPA.M.45.6.T.4 & $\begin{array}{l}\text { Complete Closure Actions } 2014 \text { Complete closure actions on one } \\
\text { operable unit or tank farm. }\end{array}$ & $3 / 31 / 2014$ \\
\hline TPA.M.45.8 & $\begin{array}{l}\text { Capability to Mitigate Waste Tank Leakage Establish full-scale } \\
\text { capability for mitigation of waste tank leakage during retrieval } \\
\text { sluicing operations. }\end{array}$ & $6 / 30 / 2003$ \\
\hline TPA.M.45.8.B & $\begin{array}{l}\text { Demonstrate Leak Monitoring System Complete demonstration } \\
\text { and installation of leak monitoring and mitigation systems for initial } \\
\text { SST: }\end{array}$ & $6 / 30 / 2003$ \\
\hline TPA.M.50.0 & $\begin{array}{l}\text { Tank Waste pretreatment Complete pretreatment processing of } \\
\text { Hanford Site tank waste. }\end{array}$ & $12 / 31 / 2028$ \\
\hline TPA.M.50.4 & $\begin{array}{l}\text { HLW pretreatment Facility Operations Start hot operations of } \\
\text { HEW pretreatment Facility. }\end{array}$ & $6 / 30 / 2008$ \\
\hline TPA.M.51.0 & HLW Vitrification Complete vitrification of Hanford Site FLW. & $12 / 31 / 2028$ \\
\hline TPA.M.51.2 & $\begin{array}{l}\text { Select and Test Melter Complete melter tests and select reference } \\
\text { melter. }\end{array}$ & $9 / 30 / 1998$ \\
\hline
\end{tabular}


Table C-7. Source Document: DOE/RL-89-10, Hanford Federal Facility Agreement and Consent Order (Tri-Party Agreement), Rev. 4. (5 Sheets)

\begin{tabular}{|c|c|c|}
\hline $\begin{array}{l}\text { HSTD } \\
\text { reference }\end{array}$ & Extracted requirement & Due date \\
\hline TPA.M.51.3 & $\begin{array}{l}\text { HIW Vitrification Facility Operations Initiate hot operations of the } \\
\text { HLW Vitritication Facility. }\end{array}$ & $12 / 31 / 2009$ \\
\hline TPA.M.S1.3.T.3 & $\begin{array}{l}\text { HLW Vitrification Facility Construction (A) Initiate construction } \\
\text { of the HLW Vitrification Facility. }\end{array}$ & $6 / 30 / 2002$ \\
\hline TPA.M.51.3.T.4 & $\begin{array}{l}\text { HLW Vitrification Facility Construction (B) Complete } \\
\text { construction of the HLW Vitrification Facility. }\end{array}$ & $12 / 31 / 2007$ \\
\hline TPA.M.60.0 & $\begin{array}{l}\text { LAW pretreatment and Immobilization Complete pretreatment } \\
\text { and immobilization of Hanford Site LAW. }\end{array}$ & $12 / 31 / 2024$ \\
\hline TPA.M.90.0 & $\begin{array}{l}\text { IHLW and ILAW Storage Complete acquisition of new facilities, } \\
\text { modification of existing facilities, and/or modification of planned } \\
\text { facilities as necessary for storage of Hanford Site IHLW and KLAW, } \\
\text { and disposal of ILAW. }\end{array}$ & $\begin{array}{l}\text { TBD; } 6 \text { months } \\
\text { after approval of } \\
\text { project } \\
\text { management plan. }\end{array}$ \\
\hline TPA.M.90.3 & $\begin{array}{l}\text { ILAW Interim Storage Facility Construction Initiate ILAW } \\
\text { Interim Storage Facility construction. }\end{array}$ & $6 / 30 / 2001$ \\
\hline TPA.M.90.6 & $\begin{array}{l}\text { ILAW Interim Storage Facility Operations Initiate hot operations } \\
\text { of ILAW Interim Storage Facility. }\end{array}$ & $12 / 31 / 2002$ \\
\hline TPA.M.90.8 & $\begin{array}{l}\text { ILAW Disposal Facility Construction Complete ILAW Disposal } \\
\text { Facility construction. }\end{array}$ & $6 / 30 / 2003$ \\
\hline TPA.M90.10 & $\begin{array}{l}\text { ILAW Disposal Facility Operations Initiate hot operations of } \\
\text { ILAW Disposal Facility. }\end{array}$ & $12 / 31 / 2005$ \\
\hline
\end{tabular}

Source: Ecology, EPA, and DOE, 1996. Hanford Federal Facility -igreement and Consent Order, 2 vols., Washington State Department of Ecology, U.S. Environmental Protection Agency, and U.S. Department of Entrgy, Olympin. Washington

Ecology $=$ Washington State Depurtment of Ecology

HI $W=$ high-level waste.

HSTD $=$ Harford Site Tcclnical Bascline Database.

IHLW = immobilized high-level waste.

II.AW = immobilized low-activity waste

LAW = low-activity waste.

SST = single-shell tank.

TBD $=$ to be determined 


\section{C1.0 REFERENCES}

Acts

Resource Conservation and Recovery Act of 1976, as amended, 42 USC 6901 et seq.

\section{Code of Federal Regulations}

10 CFR 20, 1997, "Standards for Protection Against Radiation," Code of Federal Regulations.

10 CFR 61, 1997, "Licensing Requirements for Land Disposal of Radioactive Wastes," Code of Federal Regulations.

10 CFR 830, 1997, "Nuclear Safety Management," Code of Federal Regulations.

10. CFR 835, 1993, "Occupational Radiation Protection," Code of Federal Regulations.

10 CFR 962, 1997, "By-Product Material," Code of Federal Regulations.

29 CFR 1910, 1997, "Occupational Safety and Health Standards," Code of Federal Regulations.

40 CFR 50, 1996, "National Primary and Secondary Ambient Air Quality Standards," Code of Federal Regulations.

40 CFR 61, 1997, "National Emission Standards for Hazardous Air Pollutants," Code of Federal Regulations.

40 CFR 141, 1997, "National Primary Drinking Water Regulations," Code of Federal Regulations

40 CFR 191, 1996, "Environmental Radiation Protection Standards for Management and Disposal of Spent Nuclear Fuel, High-Level and Transuranic Radioactive Wastes," Code of Federal Regulations.

40 CFR 264, 1996, "Standards for Owners and Operators of Hazardous Waste Treatment, Storage, and Disposal Facilities," Code of Federal Regulations.

40 CFR 265, 1996, "Interim Status Standards for Owners and Operators of Hazardous Waste Treatment, Storage, and Disposal Facilities," Code of Federal Regulations.

40 CFR 268, 1996, "Land Disposal Restrictions," Code of Federal Regulations.

40 CFR 279, 1996, "Standards for the Management of Used Oil," Code of Federal Regulations. 
40 CFR 761, 1996, "Polychlorinated Biphenyls (PCBs), Manufacturing, Processing, Distribution in Commerce, and Use Prohibitions," Code of Federal Regulations.

\section{Databases}

HSTD, n.d., Hanford Site Technical Baseline Database, maintained by Lockheed Martin Hanford Corporation for Fluor Daniel Hanford, Inc., Richland, Washington.

\section{Washington Administrative Code}

WAC 173-200, "Water Quality Standards for Ground Waters of the State of Washington," Washington Administrative Code, as amended.

WAC 173-201A, "Water Quality Standards for Surface Waters of the State of Washington," Washington Administrative Code, as amended.

WAC 173-303, "Dangerous Waste Regulations," Washington Administrative Code, as amended.

WAC 173-360, "Underground Storage Tank Regulations," Washington Administrative Code, as amended.

WAC 173-400, "General Regulations for Air Pollution Sources," Washington Administrative Code, as amended.

WAC 173-401, "Operating Permit Regulation," Washington Administrative Code, as amended.

WAC 173-460, "Controls for New Sources of Toxic Air Pollutants," Washington Administrative Code, as amended.

WAC 173-480, "Ambient Air Quality Standards and Emission Limits for Radionuclides," Washington Administrative Code, as amended.

WAC 246-247, "Radiation Protection--Air Emissions," Washington Administrative Code, as amended.

\section{Documents}

Burk, K. W., and D. J. Hoitink, 1996, Climatological Data Sumary 1995 with Historical DataHanford Site, PNNL-11107, Pacific Northwest National Laboratory, Richland, Washington. 
DOE, 1996, Draft Hanford Remedial Action Environmental Impact Statement and Comprehensive Land Use P/am, DOE/EIS-0222D, U.S. Department of Energy, Washington, D.C.

Ecology and EPA, 1994, Hanford Facility RCRA Permit, WA7890008967, as modified, Washington State Department of Ecology and U.S. Environmental Protection Agency, Olympia, Washington.

Ecology, EPA, and DOE, 1996, Hanford Federal Facility Agreement and Consent Order, 2 vols., Washington State Department of Ecology, U.S. Environmental Protection Agency, and U.S. Department of Energy, Olympia, Washington.

HSRCM-1, 1994, Hanford Site Radiological Control Mamial, Rev. 2, prepared for the U.S. Department of Energy, Richland Operations Office, by the Hanford Site Contractors and managed by Pacific Northwest National laboratory Records Management Office, Richland, Washington.

RL, 1996, Hanford Strategic Plan, DOE/RL 96-92, Rev. 0, U.S. Department of Energy, Richland Operations Office, Richland, Washington.

RL, 1996, Project Hanford Management Contract (PHMC), DE-AC06-96RL13200, U.S. Department of Energy, Richland Operations Office, Richland, Washington. 
HNF-SD-WM-MAR-008 Rev 3

This page intentionally left blank.

C-16 
DISTRIBUTION SHEET

\begin{tabular}{|c|c|c|c|c|c|}
\hline \multirow{2}{*}{$\begin{array}{l}\text { To } \\
\text { Document Control Services }\end{array}$} & \multirow{2}{*}{\multicolumn{3}{|c|}{ From }} & \multirow{2}{*}{\multicolumn{2}{|c|}{$\frac{\text { Page } 1:-0 f \cdot \not 1}{\text { Date January } 3,1998}$}} \\
\hline & & & & & \\
\hline \multirow{2}{*}{\multicolumn{4}{|c|}{$\begin{array}{l}\text { Project Title/Work Order } \\
\text { Tank Waste Remediation Systems (HNF-SD-AM-MAR-008) }\end{array}$}} & \multirow{2}{*}{\multicolumn{2}{|c|}{ EOT No. }} \\
\hline & & & & & \\
\hline Name & MSIN. & $\begin{array}{c}\text { Text } \\
\text { With AlT } \\
\text { Attach. }\end{array}$ & $\begin{array}{l}\text { Text } \\
\text { Oniy }\end{array}$ & $\begin{array}{l}\text { Attach./ } \\
\text { Appendix } \\
\text { Only }\end{array}$ & $\begin{array}{l}\text { EOT/ECN } \\
\text { Only }\end{array}$ \\
\hline
\end{tabular}

C.D. Acree, Jr

J.N: Alibert

J.H. Baldwin

H.L. Boston

M.P. Delozier

D.V. Freeman-

T.G. Goetz

O.A. Halverson

D.M. Hammond

J.P. Harris, III

J.0. Honeyman

K.N. Jordan

R.A. Kirkbride

S.C. Klimper

R.J. Murkowski

S.M. O'Toole

R.J. Parazin

M.A. Payne

L.G. Peck

R.W. Powell

R.P. Raven

R.E, Raymiond

S.H. Rifaey

B. Root

P.S. Schaus

S.E. Seeman

S.J. Simon

R.L. Treat

J.M. Vann

J.H. Wicks' Jr

A.D. Willis III

R.D. Wojtasek

B.D. Zimmerman
H6-35

S2 -48

H5- 03

G3-21

R2-58

G3-21

R1-49

G3-21

RI- 44

RI- 49

G3-21

G3-21

H5-27.

H6- 25

H6-37.

G3-21

H5 -49

R2-58

H6-35

H5-03

RI -51

R2-38

RI-56

G3-21

H5- 03

H6-35

H7-06

H5- 03

H6-37

H7-07

$57-51$

G3-21

H6-35 $x$

$x$

$x$

$x$

$x$

$x$

$X$

$x$

$x$

$x$

$x$

$x$

$x$

$x$

3 copies

$x$

$x$

$x$

$x$

$x$

$\mathrm{X}$

$x$

$x$

2 copies

$-x$

$x$

$x$

3 copies

$x$

$x$

$x$

3 copies

Central Files

B T-07

$x$

